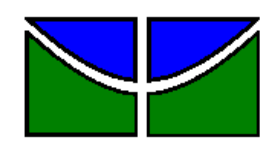

Universidade de Brasília

Centro de Excelência em Turismo

Pós-graduação Lato Sensu

Curso de Especialização em Gestão de Negócios em Turismo

\title{
PROJETO FAZENDA HOTEL RANCHO GRANDE - FORMOSA/GO: Plano Financeiro
}

\section{LARISSA UCHÔA DA ROCHA}

Brasília - ano 2009 


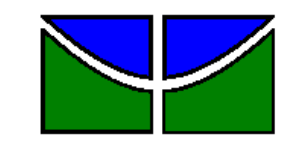

Universidade de Brasília

Centro de Excelência em Turismo

Pós-graduação Lato Sensu

Curso de Especialização em Gestão de Negócios em Turismo

\title{
PROJETO FAZENDA HOTEL RANCHO GRANDE - FORMOSA/GO: Plano Financeiro
}

\author{
Larissa Uchôa da Rocha \\ Professor Orientador: Gilson Borda, Dr.
}

Monografia apresentada ao Centro de Excelência em Turismo da Universidade de Brasília - CET/UnB, como requisito parcial à obtenção do grau de Especialista em Gestão de Negócios em Turismo.

Brasília - ano 2009 
Uchôa, Larissa.

Projeto Fazenda Hotel Rancho Grande - Formosa/GO: Plano Financeiro / Larissa Uchôa. - Brasília, 2009.

Monografia (especialização) - Universidade de Brasília, Centro de Excelência em Turismo, 2009.

Orientador: Gilson Borda.

1. Turismo. 2. Fazenda Hotel. 3. Plano Financeiro. 


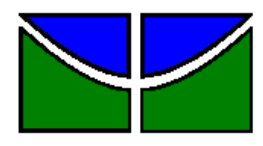

Universidade de Brasília

Centro de Excelência em Turismo

Pós-graduação Lato Sensu

Curso de Especialização em Gestão de Negócios em Turismo

\section{PROJETO FAZENDA HOTEL RANCHO GRANDE - FORMOSA/GO: Plano Financeiro}

Larissa Uchôa da Rocha

Aprovado por:

Professor orientador: Gilson Borda - Doutor

Professor Avaliador: Nome e Titulação

Professor Avaliador: Nome e Titulação

Brasília, .... de .................... de 200... 


\section{RESUMO}

Esta obra tem como objetivo apresentar a realização de um plano financeiro necessário para verificar a viabilidade de implementação da fazenda hotel na Fazenda Rancho Grande na cidade de Formosa, GO. Se faz necessária a criação desse plano, por se tratar de um documento de planejamento que apresenta a realidade e as perspectivas da empresa e define as estratégias necessárias para implementação desse empreendimento. Porém, para essa obra optou-se por dar ênfase ao plano financeiro, etapa do plano de negócios, que analisa a viabilidade econômica do empreendimento, e apresenta os investimentos necessários, capital de giro, custos, despesas, além de outros indicadores orçamentários. Assim, esse estudo conclui a viabilidade de implementação da fazenda hotel na propriedade Fazenda Rancho Grande proposto nesse trabalho, além de mostrar os riscos e as chances do sucesso do negócio, uma vez que os passos aqui delineados devem ser seguidos minimamente.

1. Turismo

2. Fazenda hotel

3. Plano financeiro 


\begin{abstract}
The objective of this essay is to present a business plan to demonstrate the viability to invest at the "Fazenda Rancho Grande" to lodge a Country Hotel, located at Formosa County, a beautiful place nearby Brasilia, the Capital of Brazil. As part of the carefully planning of the entire project, this business plan becomes essential to show the great perspective from the financial investment viewpoint, dealing in detail with costs, working money, the expected capital expenditure, as well as maintenance expenditures. On the other hand the issue also shows the revenue and the profitability if the business plan is to be implanted the way it has been conceived.
\end{abstract}

Keywords:

1. Tourism 2 Country Hotel Financial plan 


\section{SUMÁRIO}

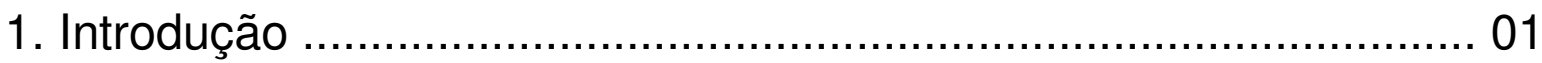

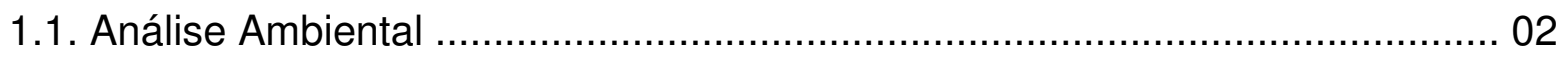

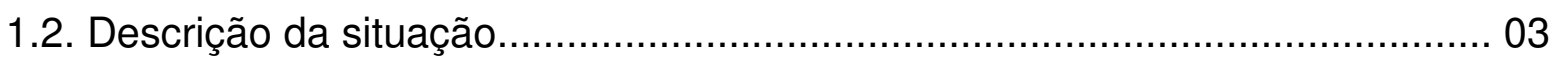

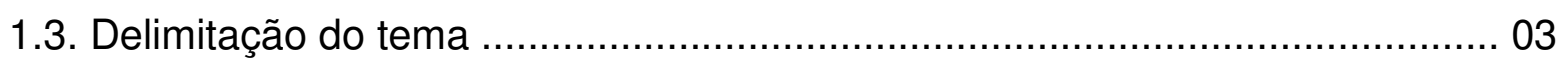

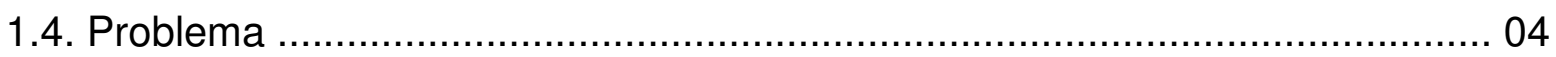

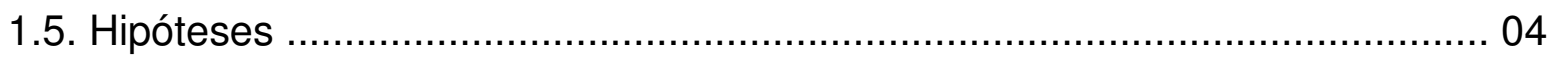

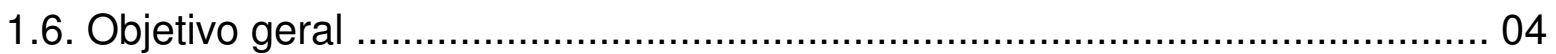

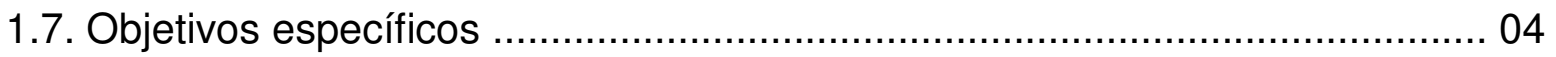

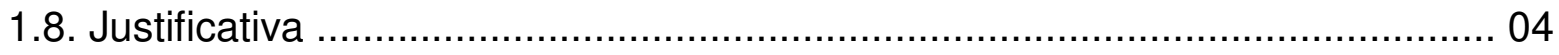

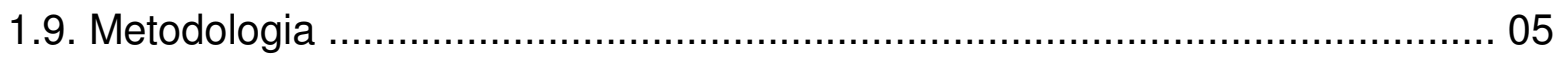

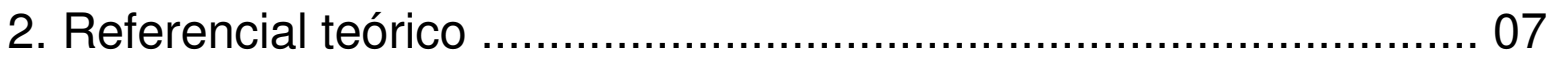

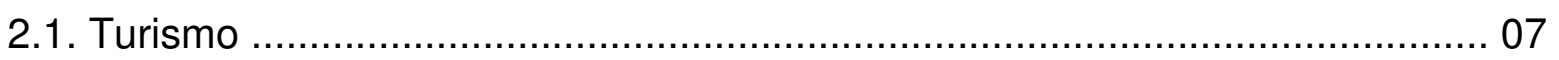

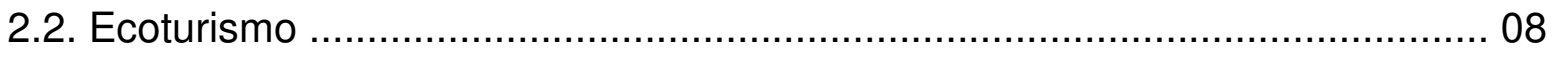

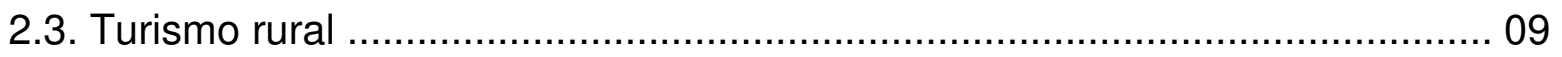

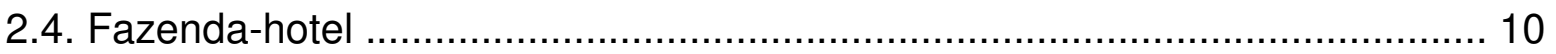

2.5. Plano de negócios ............................................................................. 12

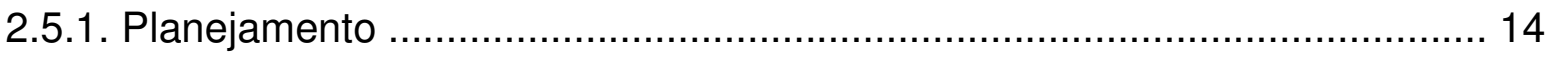

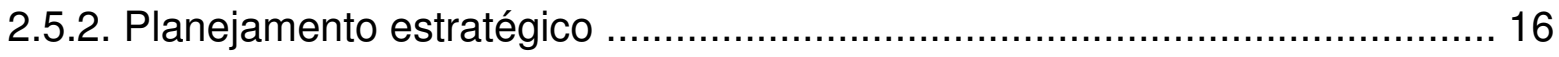

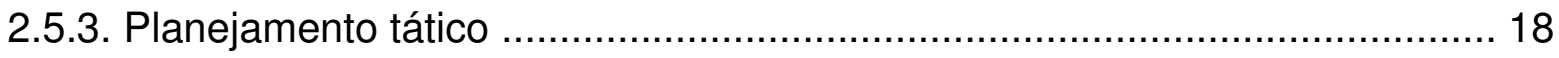

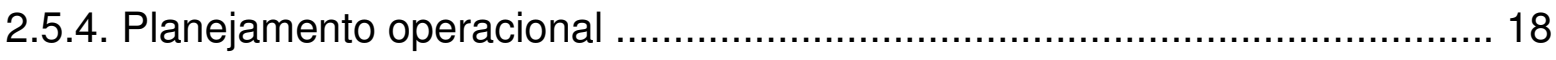

2.6. Etapas do plano de negócios …………………................................... 19

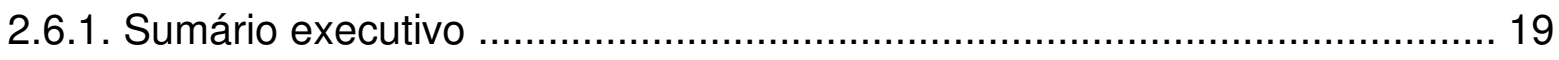

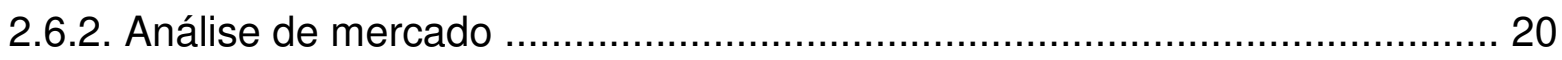

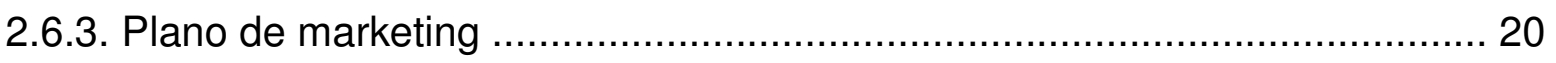




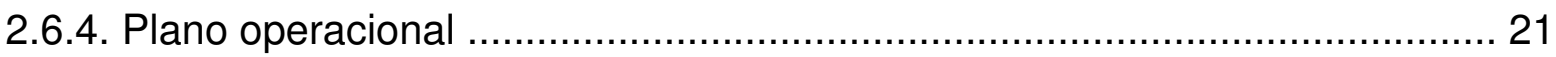

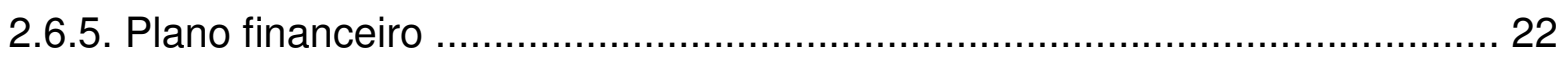

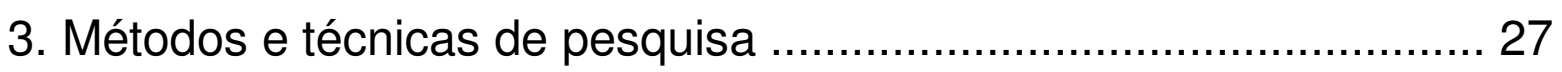

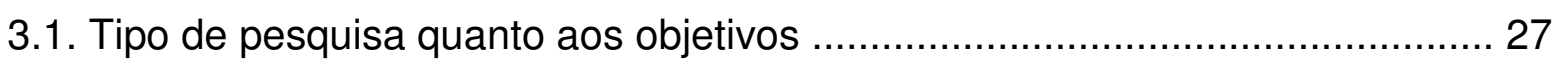

3.2. Pesquisa quanto aos procedimentos técnicos ..................................... 28

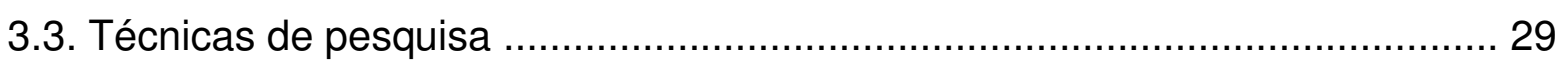

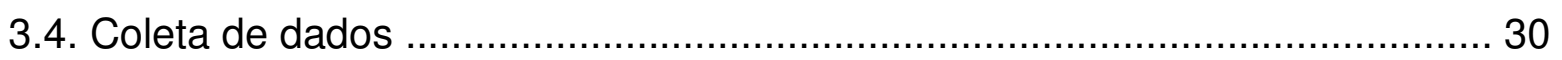

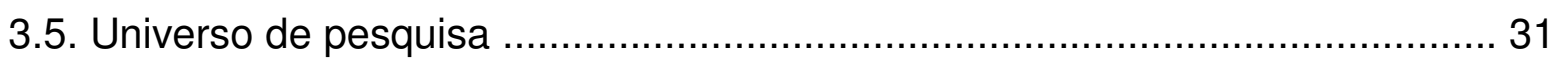

4. Descrição da Organização Pesquisada .................................... 32

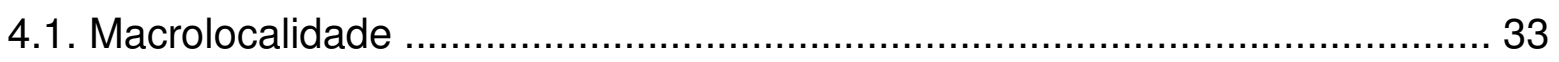

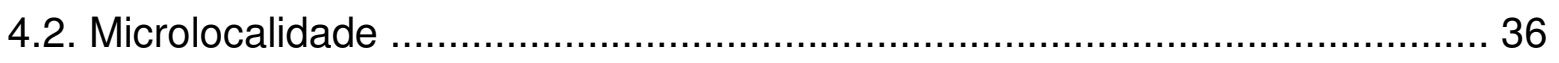

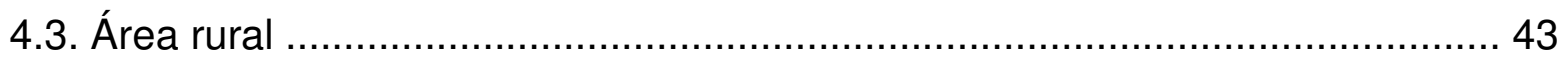

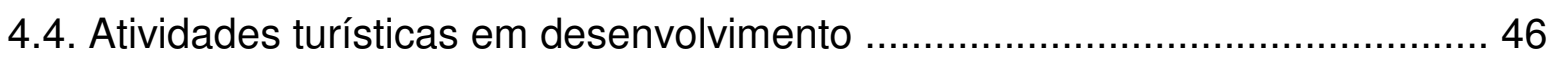

4.5. Memorial descritivo do potencial turístico da Fazenda Rancho Grande ........ 47

5. Plano financeiro da Fazenda Hotel Rancho Grande ................... 50

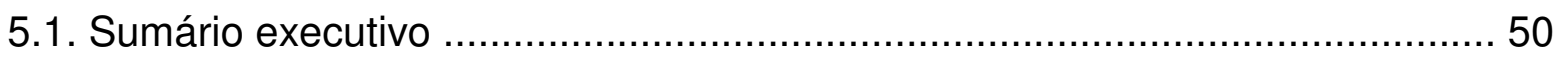

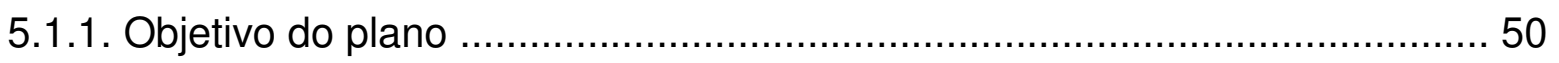

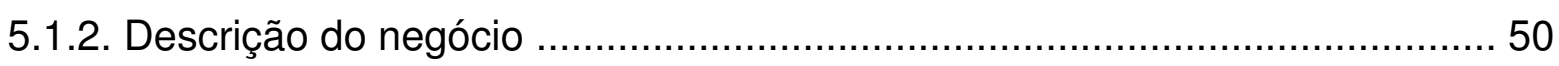

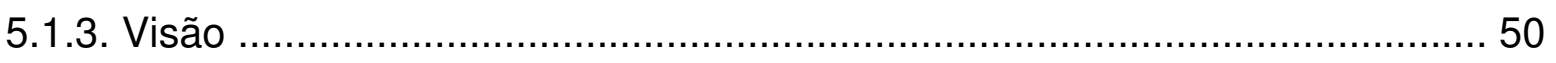

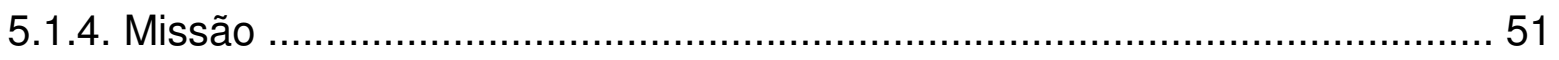

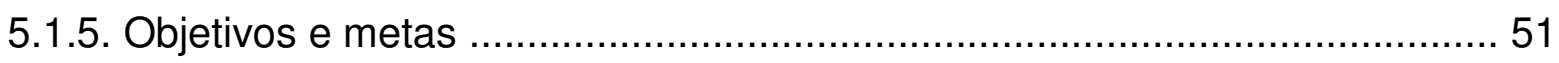

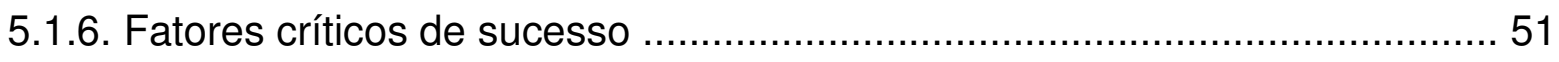

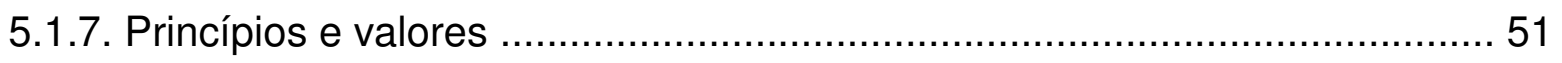

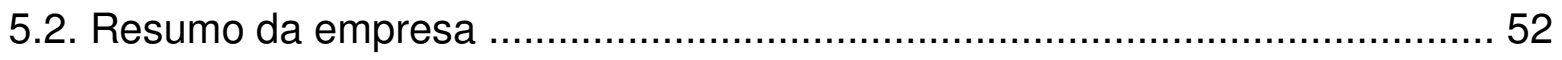

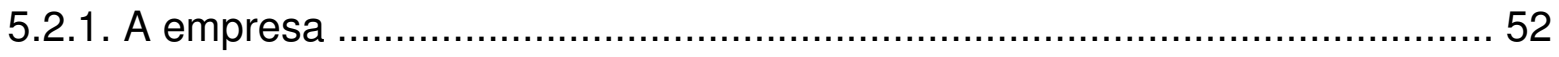

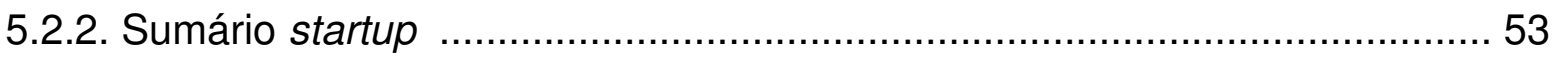




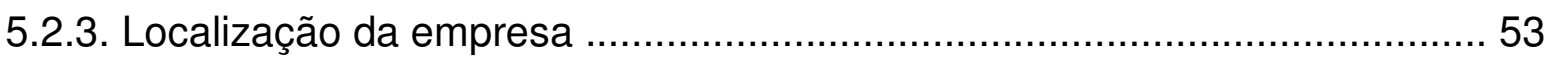

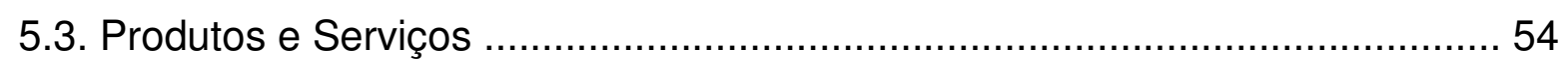

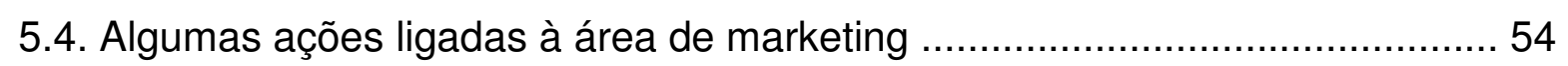

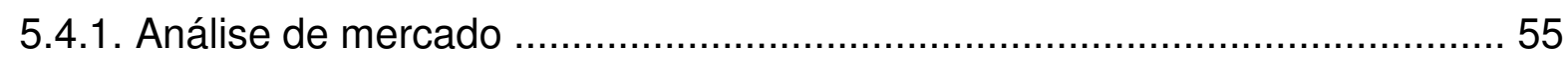

5.4.2. Análise SWOT do empreendimento ..................................................... 56

5.5. Algumas ações ligadas à área operacional ................................................ 56

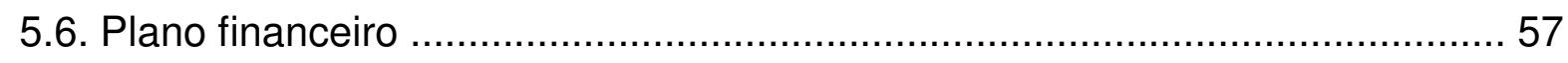

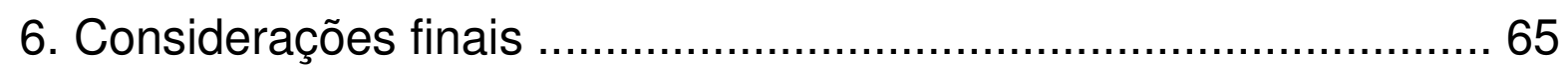

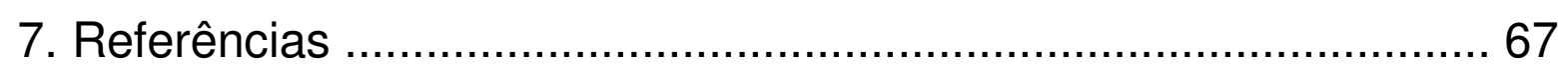

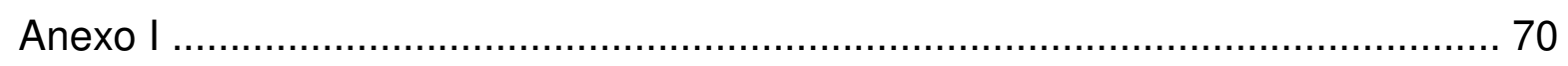

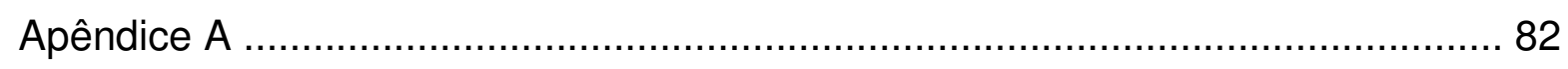

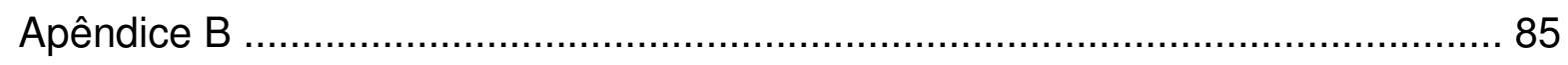

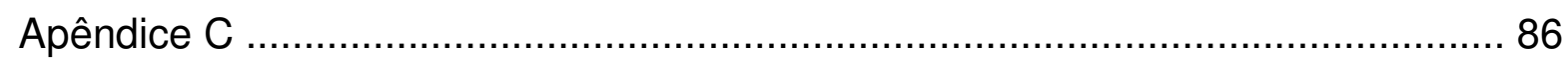

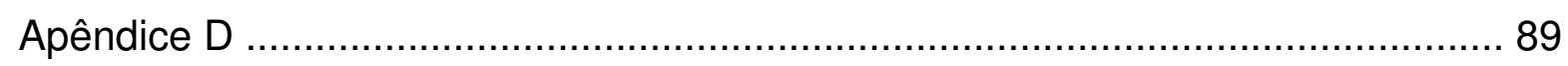




\section{LISTA DE ABREVIATURAS E SIGLAS}

ABIH - Associação Brasileira da Indústria de Hotéis.

APROVA - Associação dos Produtores do Vão do Paranã.

EMATER - Empresa de Assistência Técnica e Extensão Rural.

EMBRATUR - Instituto Brasileiro de Turismo.

IBAMA - Instituto Brasileiro do Meio Ambiente e dos Recursos Naturais Renováveis.

OMT - Organização Mundial de Turismo.

SEBRAE - Serviço Brasileiro de Apoio às Micro e Pequenas Empresas.

SWOT - Strengh, Weakness, Opportunities and Threats.

TIR - Taxa Interna de Retorno.

VPL - Valor presente líquido 


\section{LISTA DE ILUSTRAÇÕES}

Figura 1 - Porteira de entrada e mata-burro ………...................................... 37

Figura 2 - Caixa d'água da casa-sede …..................................................... 38

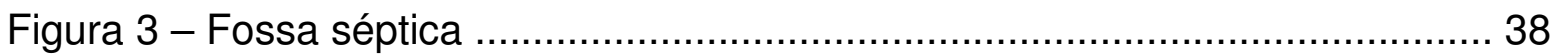

Figura 4 - Árvore típica do Cerrado ……….................................................... 40

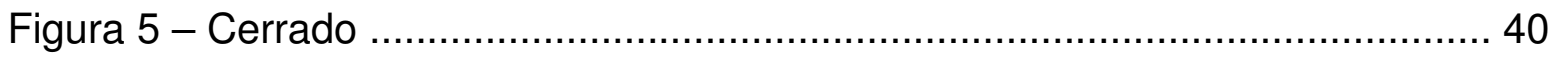

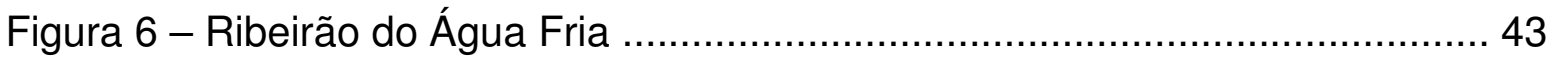

Figura 7 - Ribeirão do Água Fria ................................................................... 43

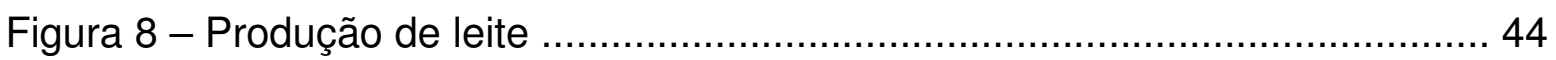

Figura 9 - Produção de leite ........................................................................ 44

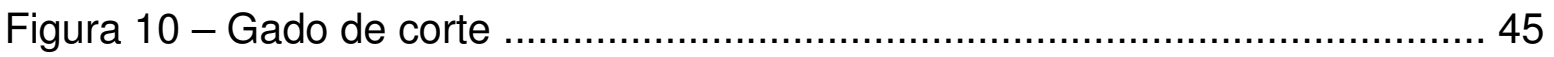

Figura 11 - Primeira fase da produção de queijo, separação do leite e do soro ... 45

Figura 12 - Última fase da produção de queijo, o queijo pronto para consumo .... 45

Figura 13 - Plantação de milho ............................................................... 46

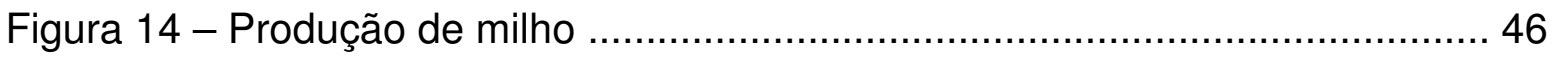

Ilustração 1 - Planta cadastral da propriedade Fazenda Rancho Grande ............ 85

Mapa 1 - Mapa geográfico da região de Formosa/GO e DF ................................ 33

Mapa 2 - Imagem de satélite do município de Formosa/GO …….......................... 34

Mapa 3 - Mapa do terreno de Formosa/GO ………….................................. 34

Mapa 4 - Mapa rodoviário da região de Formosa/GO e DF ................................ 35

Mapa 5 - Mapa rodoviário da região de Formosa/GO e DF ................................ 35

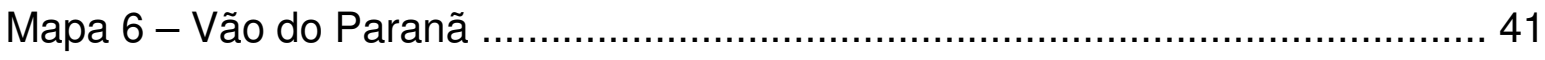

Mapa 7 - Mapa hidrográfico de Goiás ………………................................ 42

Mapa 8 - Parte da planta cadastral da propriedade Fazenda Rancho Grande ..... 48 


\section{LISTA DE TABELAS}

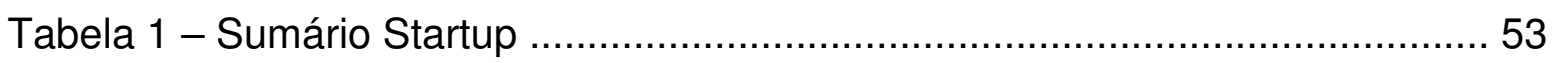

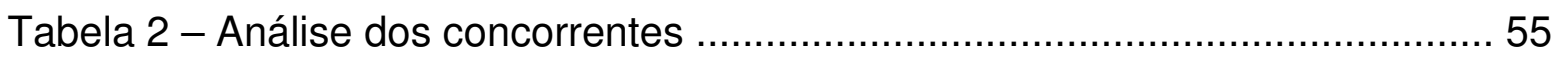

Tabela 3 - Análise do Concorrente 1 ............................................................. 55

Tabela 4 - Análise do Concorrente 2 …………........................................... 55

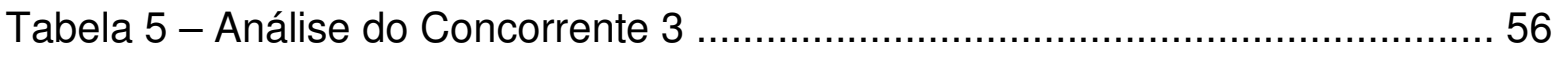

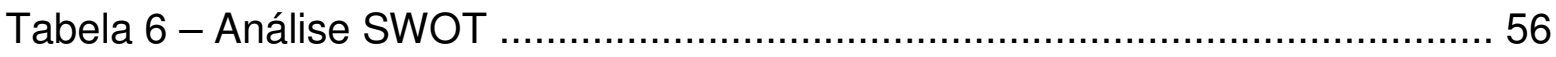

Tabela 7 - Estrutura física básica .............................................................. 57

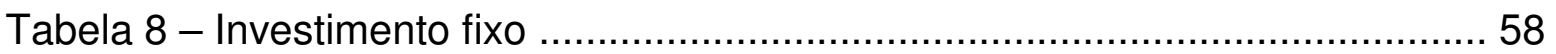

Tabela 9 - Consolidação do Investimento Inicial .................................................. 59

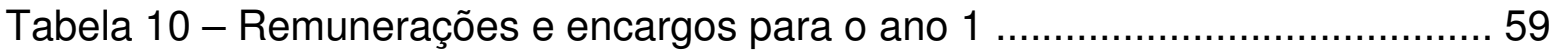

Tabela 11 - Remunerações e encargos para o ano 2 ....................................... 60

Tabela 12 - Remunerações e encargos para o ano 3 ....................................... 60

Tabela 13 - Remunerações e encargos para o ano 4 ........................................ 60

Tabela 14 - Remunerações e encargos para o ano 5 ........................................ 60

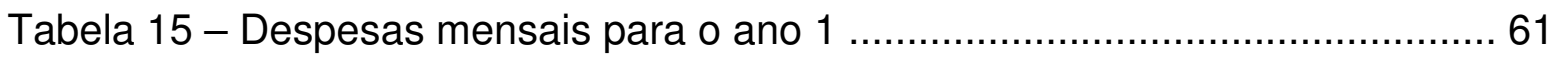

Tabela 16 - Despesas mensais para o ano 2 ................................................ 61

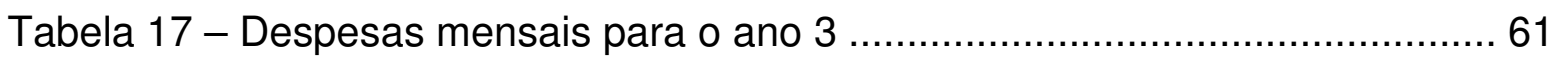

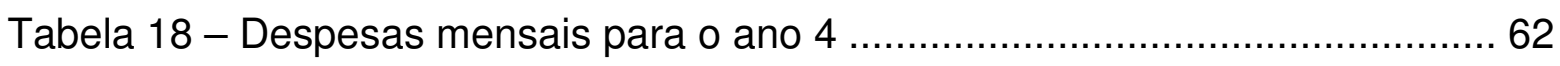

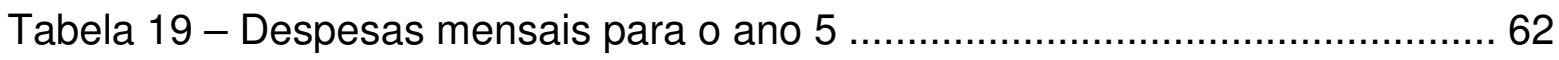

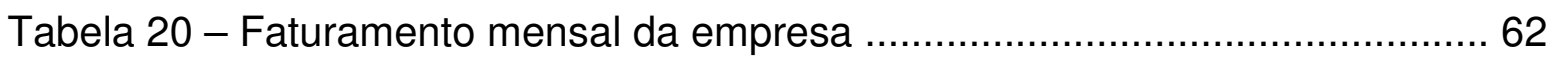

Tabela 21 - Projeção de custos fixos e variáveis da empresa ............................... 63

Tabela 22 - Margem de contribuição e ponto de equilíbrio ................................... 64

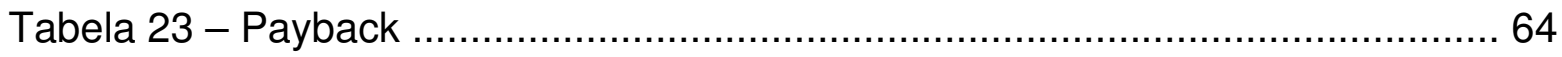

Tabela 24 - Fluxo de caixa mensal - Ano 1 ..................................................... 89 


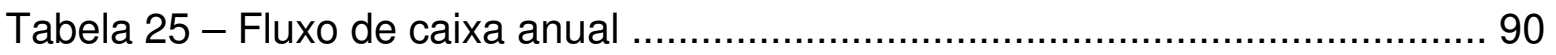

Tabela 26 - Demonstrativo anual ............................................................... 91

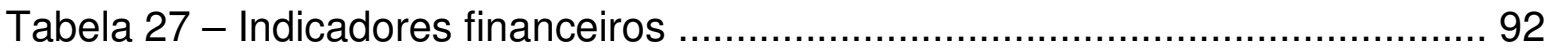




\section{INTRODUÇÃO}

O tema Projeto Fazenda Hotel Rancho Grande: Plano Financeiro foi escolhido, ao perceber a potencialidade natural da propriedade para implementação de um serviço turístico de qualidade para pessoas que buscam sair do seu entorno habitual para relaxar e entrar em contato com a natureza.

Ao iniciar os estudos para elaboração desse trabalho de conclusão de especialização, observou-se a necessidade de apresentar os conceitos de turismo, turismo rural, ecoturismo e fazenda hotel, diferenciando-a de hotel-fazenda, por se tratar da razão da escolha desse tipo de empreendimento para implementação na Fazenda Rancho Grande, localizada em Formosa/GO, objeto de estudo desse trabalho de conclusão de especialização, que serão apresentados detalhadamente no capítulo 2.

No mundo atual, os empreendedores, aqueles que identificam as melhores oportunidades de negócios e sabem aproveitá-las, têm pertencido ao mundo empresarial e dos negócios. Esses empreendedores têm pensado, cada vez mais, sobre os fatores que envolvem o negócio a que pertencem e sobre um planejamento bem detalhado para que suas atividades possam ser iniciadas.

Desta forma, para iniciar um negócio bem planejado, se faz necessário a criação de um plano de negócios, que é conceituado por Salim, Hochman, Ramal e Ramal como "um documento que contém a caracterização do negócio, sua forma de operar, suas estratégias, seu plano para conquistar uma fatia do mercado e as projeções de despesas, receitas e resultados financeiros" (SALIM, 2005. P. 03). O plano de negócios é importante para que a empresa saiba para onde vai e como chegará onde propôs chegar.

Ao apresentar o conceito de plano de negócios proposto por Salim, Hochman, Ramal e Ramal, percebe-se a real necessidade de apresentar um plano para que o empreendimento seja administrado de forma competente e sustentável para conquistar os passos propostos de sucesso.

Para iniciar o planejamento desse empreendimento se faz necessária uma avaliação ambiental e da situação da propriedade, apresentando os objetivos 
gerais e específicos, além de apresentar a justificativa para elaboração do plano de negócios para a Fazenda Rancho Grande, onde será dada ênfase no plano financeiro, etapa do plano de negócios.

\subsection{Análise Ambiental}

Formosa é um município brasileiro do nordeste do estado de Goiás que situa-se a 75 quilômetros de Brasília, e a 272 quilômetros de Goiânia. A população desse município em 2005 era de 90.247 habitantes.

Surgiu em meados do século XVIII, quando Goiás pertencia à capitania de São Paulo. A cidade foi formada por antigos moradores do Arraial de Santo Antônio, no vale do Paranã, que fugiram de seu povoado depois que uma forte epidemia de malária assolou a região. Com medo da doença, tropeiros e comerciantes que vinham da Bahia e de Minas Gerais acampavam na região onde hoje está localizada Formosa. O povoado foi batizado de Arraial dos Couros em homenagem aos viajantes que acampavam no local em barracas de couro que eles traziam para comercializar. A criação do município de Formosa deu-se em $1^{\circ}$ de agosto de 1843. Cidade de importante riqueza natural, com grande número de cachoeiras. Dentre elas destaca-se a Cachoeira do Itiquira que localiza-se a 34 quilômetros do centro da cidade e se destaca por ser umas das mais altas da América Latina com 168 metros de altura. Outro ponto muito conhecido é a Lagoa Feia, com 06 (seis) quilômetros de comprimento e 0,5 (meio) quilômetro de largura e com profundidade entre 4 e 10 metros. Há ainda o Lajedo que forma grandes piscinas naturais, a Gruta das Andorinhas com aproximadamente 250 metros de profundidade, o Buraco das Araras com aproximadamente 100 metros de profundidade e o Rio Bandeirinha o qual forma várias cachoeiras. O município possui três distritos: Distrito Bezerra, Distrito JK e Distrito de Santa Rosa. O município possui sete municípios limítrofes: Água Fria de Goiás (onde se localiza a propriedade em estudo), Planaltina, Cabeceiras, São João d'Aliança, Flores de Goiás, Vila Boa, Distrito Federal e Cabeceira Grande. 


\subsection{Descrição da situação}

Identifica-se que o turismo rural é uma atividade que se desenvolve no meio rural associada às atividades agropecuárias da propriedade, aqui, da Fazenda Rancho Grande, objeto de estudo desse trabalho de conclusão de especialização. Escolheu-se adotar a terminologia de fazenda hotel, pois observa-se que a montagem do hotel na fazenda não vem a se tornar a atividade principal e sim agregar valor ás atividades agropecuárias da propriedade, por intermédio do turismo.

Para que a fazenda hotel seja implementada na Fazenda Rancho Grande, faz-se necessário um planejamento turístico para que a atividade aconteça de forma sustentável e agregada às atividades agropecuárias da propriedade, pois dessa forma pode-se conhecer os fatos, observar, ser objetivo e admitir possíveis erros para que o projeto seja bem administrado.

Nesse trabalho foi feita uma análise do plano financeiro da fazenda, fase do plano de negócios, para que se possa mostrar seu potencial turístico. Porém para que a atividade venha a ser implementada é necessário que esse estudo seja continuado através da identificação das necessidades de reforma e implementação de equipamentos turísticos para a segurança do usuário e preservação do meio ambiente, feita por meio de propostas definidas pelo plano de marketing e plano operacional.

O objeto dessa pesquisa é a propriedade Fazenda Rancho Grande situada no município de Formosa/GO, cujo proprietário, Carlos Magno Campos da Rocha, tem como objetivo principal a criação de um negócio que venha agregar valor às atividades já existentes na propriedade como criação de gado de leite e de corte.

\subsection{Delimitação do tema}

Observa-se que o turismo rural é uma oportunidade de negócio na região, e por isso a importância da construção de um planejamento turístico através de um plano de negócios para a implementação da fazenda hotel na Fazenda Rancho Grande, que visa a realização de um sonho, além de apresentar a viabilidade da construção desse tipo de empreendimento. Assim, delimita-se o tema: Projeto Fazenda Hotel Rancho Grande - Formosa/GO: Plano financeiro. 


\subsection{Problema}

Levando em consideração a existência de três empreendimentos turísticos voltados à hotelaria em meio rural, e $32 \mathrm{~km}$ de estrada de cascalho, surge o problema de pesquisa: é viável a implantação de uma empresa de hotelaria em meio rural na cidade de Formosa, GO?

\subsection{Hipóteses}

- Hipótese Positiva: pelos dados apresentados, aparentemente é viável a implementação da fazenda hotel na propriedade Fazenda Rancho Grande.

- Hipótese negativa: de acordo com os dados levantados não há base para dizer se é viável a implementação da fazenda hotel na propriedade Fazenda Rancho Grande.

\subsection{Objetivo Geral}

Avaliar a viabilidade econômico-financeira para implementação da fazenda hotel na Fazenda Rancho Grande.

\subsection{Objetivos Específicos}

- Verificar a concorrência de hotéis na região de Formosa/GO;

- Levantar dados econômicos financeiros para viabilizar a montagem da fazenda hotel; e,

- Avaliar os dados identificados para implementação da fazenda hotel na Fazenda Rancho Grande.

\subsection{Justificativa}

Segundo Meirelles Filho (MEIRELES FILHO, 2003. P. 25), o turismo rural pode tornar-se "[...] a grande alternativa para as propriedades rurais no Brasil. A agricultura e a pecuária já não são tão rentáveis, e fazendeiros com a corda no 
pescoço descobrem que podem obter bons lucros abrindo suas propriedades para o turismo". Por isso, a decisão de se abrir um negócio em meio rural.

Para se organizar as idéias direcionadas à abertura de uma empresa, deve-se criar o plano de negócios para que haja uma orientação na busca detalhada de informações sobre esse ramo empresarial, seus produtos e serviços a oferecer. Através desse plano, também, é possível fazer uma análise da concorrência, do perfil dos clientes, e principalmente observar os pontos fortes e pontos fracos do negócio, contribuindo para a viabilização dessas idéias e da gestão empresarial.

Um plano de negócios bem elaborado e com clareza pode ser utilizado para se conquistar novos sócios e investidores, estabelecer parcerias com fornecedores ou clientes, além de ser apresentado em bancos para solicitações de financiamento. Nesse trabalho destacou-se uma parte do plano de negócios, o plano financeiro, pois o plano de negócios é um projeto extenso e minucioso que necessita de grande quantidade de tempo para sua realização.

\subsection{Metodologia:}

Para elaboração do plano financeiro da fazenda hotel na Fazenda Rancho Grande foi feito um estudo bibliográfico para sua elaboração e a busca de dados sobre a região por meio de entrevista com o proprietário, junto aos órgãos municipais e principais concorrentes.

Dessa forma, o presente trabalho foi dividido da seguinte forma:

Capitulo 1 - Introdução - apresenta a delimitação do tema, problema da pesquisa, objetivos e justificativa.

Capítulo 2 - Referencial Teórico - analisa os principais autores que referenciam o tema e delimita o modelo de plano financeiro utilizado.

Capítulo 3 - Métodos e Técnicas de pesquisa - demonstra os métodos e procedimentos utilizados para elaboração desse projeto de conclusão de especialização.

Capítulo 4 - Descrição da Organização Pesquisada - apresenta o inventário turístico realizado em 2008 como início do projeto de implementação de hotel na Fazenda Rancho Grande. 
Capítulo 5 - Plano financeiro da Fazenda Hotel Rancho Grande - apresenta a análise e interpretação dos dados para desenvolvimento do plano financeiro.

Capítulo 6 - Considerações Finais - avalia a viabilidade ou não da implementação da fazenda hotel na propriedade de acordo com a análise dos dados apresentados no capítulo anterior. 


\section{REFERENCIAL TEÓRICO}

Por meio de um estudo bibliográfico sobre conceitos de turismo rural e ecoturismo, este capítulo tem como objetivo especificar esses segmentos turísticos com conceitos propostos por autores e pelo Ministério do Turismo. Posteriormente, será apresentado o conceito sobre fazenda hotel e a razão da escolha desse tipo de empreendimento para implementação na Fazenda Rancho Grande, além de diferenciar essa terminologia de hotel-fazenda.

Porém, para se entender o que é o turismo rural e o ecoturismo deve-se entender o que é o turismo e sua segmentação.

\subsection{Turismo}

Segundo a Embratur (Instituto Brasileiro de Turismo), turismo:

É uma atividade econômica representada pelo conjunto de transações compra e venda de serviços turísticos efetuadas entre os agentes econômicos do turismo. É gerado pelo deslocamento voluntário e temporário de pessoas fora dos limites da área ou região em que têm residência fixa, por qualquer motivo, excetuandose $o$ de exercer alguma atividade remunerada no local que visita. (EMBRATUR, 2009).

O conceito apresentado pela Embratur é datado de muitos anos, por isso, se faz necessária a apresentação de um conceito mais recente.

Turismo, segundo a OMT (Organização Mundial de Turismo), compreende "as atividades que as pessoas realizam durante viagens e estadas em lugares diferentes do seu entorno habitual, por um período inferior a um ano com finalidade de lazer, negócios ou outros" (OMT, 2009). Assim, com a definição do conceito de turismo proposto pela OMT segmentou-se o turismo, essa segmentação é uma forma de organizar o turismo para fins de planejamento, gestão e mercado. Os segmentos de turismo podem ser estabelecidos por meio de estudos da oferta ou demanda turística.

Levando-se em consideração a oferta turística, segmenta-se o turismo nos seguintes tipos: turismo social, ecoturismo, turismo cultural, turismo de estudos e intercâmbio, turismo de esportes, turismo de pesca, turismo náutico, turismo de 
aventura, turismo de sol e praia, turismo de negócios e eventos, turismo rural e turismo de saúde. (MINISTÉRIO DA SAÚDE, 2006. P. 1)

Para esse trabalho de conclusão de especialização serão apresentados os conceitos de turismo rural e ecoturismo por nortearem a elaboração desse plano.

\subsection{Ecoturismo}

O Ministério do Turismo define ecoturismo como um "segmento da atividade turística que utiliza, de forma sustentável, o patrimônio natural e cultural, incentiva sua conservação e busca a formação de uma consciência ambientalista através da interpretação do ambiente, promovendo o bem-estar das populações" (MINISTÉRIO DA SAÚDE, 2006. P. 9). O conceito do Ministério do Turismo é o mais utilizado.

De acordo com estudos bibliográficos realizados por Costa, os pontos que constituem a base do que é o ecoturismo são: é uma atividade econômica; promove o uso sustentável dos recursos; busca a conscientização ambiental; e envolve as populações locais (COSTA, 2002. P. 31).

Costa (COSTA, 2002) ainda propõe uma busca a dicionários renomados para se entender o conceito de ecoturismo e o diferenciá-lo de turismo rural através da definição do rural e do natural. Seguindo esta recomendação pesquisou-se no dicionário ilustrado de Koogan/Houaiss sobre o referido tema:

- Rural: adj. Referente ao campo, que é próprio do campo; agrícola, campestre: vida rural (KOOGAN, 2000. P. 1420).

- Natural: adj. Que se refere ou pertence à natureza. Produzido pela natureza ou de acordo com suas leis (KOOGAN, 2000. P. 1130).

Assim, pode-se observar que o rural diz respeito ao ambiente ou meio em que o homem se insere, sendo alterado pelo homem; e o natural diz respeito à natureza sem ter sido alterado pelo homem. Essas definições podem ser bem observadas no Brasil onde há uma natureza exuberante, e um vasto território, e áreas rurais com potencialidades a serem exploradas pelo turismo.

O ecoturismo tinha como nomenclatura turismo ecológico no fim da década de 1980, no Brasil. Nesse mesmo ano surge a primeira iniciativa do governo para 
ordenar o mercado turístico na natureza, por intermédio da Embratur e do Ibama (Instituto Brasileiro do Meio Ambiente e dos Recursos Naturais Renováveis). Na década de 1990, convencionou-se a utilização do termo ecoturismo.

As Nações Unidas juntamente com a OMT estabeleceram o ano de 2002 como o ano Internacional do Ecoturismo, reconhecendo assim, a importância econômica e social que o ecoturismo vem adquirindo em nível mundial. Essa ação teve como objetivo estimular governos, empresários, comunidades receptoras e o turista a buscar essa atividade para que tornasse um motor para o desenvolvimento sustentável e não um obstáculo.

Cabe aqui ressaltar que sustentabilidade é o "desenvolvimento capaz de atender às necessidades da geração atual sem comprometer os recursos para a satisfação das gerações futuras" (MINISTÉROP DO TURISMO, 2006. P. 13). Esse conceito foi desenvolvido para evitar riscos que podem ser causados ao meio ambiente, devendo proteger a cultura e as características da comunidade receptora, as paisagens e os hábitats. O ecoturismo pode ser considerado um dos meios de conservar a diversidade biológica, segundo o Ministério do Turismo.

\subsection{Turismo Rural}

O Ministério do Turismo define o turismo rural como "o conjunto de atividades turísticas desenvolvidas no meio rural, comprometido com a produção agropecuária, agregando valor a produtos e serviços, resgatando e promovendo o patrimônio natural e cultural da comunidade" (MINISTÉRIO DO TURIMSO, 2006. P. 49). Esse conceito está fundamentado em aspectos que se referem ao turismo, ao território, à sociedade, à base econômica e aos recursos naturais e culturais.

A EMATER (Empresa de Assistência Técnica e Extensão Rural) define o turismo rural como "segmento do turismo baseado na oferta de serviços, como hospedagem, alimentação, e serviços relacionados a empresas (ou propriedades) que atuam no meio rural e têm por base economia não agrícola" (EMATER, 1998. P. 10). Na prática, o agroturismo se confunde com o turismo rural, as características agregadas ao agroturismo são seguidas pelo turismo rural, que inclui meios de hospedagem que reproduzem estruturas urbanas, como hotéisfazenda e spas. 
Segundo Tulik, "turismo rural é o conjunto de atividades que se desenvolvem em contato com a natureza e a vida no campo, em pequenos povoados rurais" (TULIK, 2003. P. 34).

Com esses conceitos apresentados, observa-se que o turismo rural envolve atividades e produtos como fazenda hotel, pesque-pague, fazenda de caça, pousada, restaurante típico, artesanato, industrialização caseira, que são consideradas estratégias para diversificação das atividades rurais com o intuito de promover o aumento da renda dos proprietários rurais, constituindo atividades internas à propriedade e de valor complementar às atividades da propriedade. Por isso, a escolha do turismo rural como terminologia norteadora da implementação da fazenda hotel na Fazenda Rancho Grande.

Conceitos formulados pela Embratur demonstram a evolução dos conceitos de turismo rural desde 1994. O Manual Operacional do Turismo Rural publicado no mesmo ano explica: "o Brasil adotou para o turismo rural um conceito múltiplo - um turismo diferente, turismo de interior, turismo doméstico, turismo integrado, turismo endógeno, turismo alternativo, agroturismo e turismo verde" (EMBRATUR, 1994. P. 08). Observa-se que a zona rural deve englobar atividades nas áreas de produção e nas áreas naturais, a característica aqui, é a de pluriatividade. O objetivo desse manual é de apresentar e sugerir alguns modelos de funcionamento e gestão do que se entende como turismo rural.

Há um consenso na literatura sobre os principais objetivos do turismo rural: complementar a renda, gerar emprego e promover o desenvolvimento local.

Juntamente com o turismo rural e o ecoturismo, escolheu-se utilizar a terminologia fazenda hotel para implementação desse empreendimento como será apresentado a seguir.

\subsection{Fazenda Hotel}

Para o projeto de implementação do plano financeiro na propriedade Fazenda Rancho Grande, decidiu-se adotar o termo fazenda hotel já que esse se diferencia do termo hotel-fazenda. 
Hotel-fazenda é entendido como um hotel similar aos outros, porém encontra-se instalado no meio rural integrando atividades típicas da zona rural aos seus serviços, o hotel em si é a atividade mais importante da propriedade.

Fazenda hotel constitui em montar um hotel na fazenda e não transformar a fazenda em um hotel, não é a atividade principal da fazenda, já que a propriedade agrícola continua com suas atividades e agrega o hóspede a essas atividades, como a ordenha diária. Não há uma preocupação excessiva com o conforto quando se procura esse tipo de hotel, já que o turista está interessado em participar das atividades da propriedade agrícola, como explica Silva e Baldan:

A fazenda hotel está voltada para uma clientela urbana cada vez mais carente de
contato com o cotidiano da terra, com a rotina de um modo de vida que, pelo
menos no imaginário urbano, remete a uma reconciliação com a natureza [...]
aqui as atrações não são ornamentais e isso é decisivo para o seu sucesso com
um público saturado de simulações e banalizações impostas pelo mercado de
consumo. A característica básica desses empreendimentos é que as fazendas
continuam produtivas. Além de andar a cavalo, contemplar paisagens e praticar
esportes, os hóspedes podem vivenciar rotinas como a ordenha e a alimentação
do gado, o trato dos suínos e as colheitas. Um ingrediente que instiga, seduz e
informa.(SILVA;BALDA, 1997 apud SILVA, VILARINHO, DALE, 2003. P. 47). É pertinente distinguir o termo Pousada do termo Hotel, pois quando se fala em hotelaria logo se pensa em grandes complexos de hospedagem ou muitos apartamentos. Hoje em dia o que cresce e se moderniza são as pousadas e seus donos estão incluindo em seus negócios atrativos com qualidade e profissionalismo, são os negócios com perfil menor, que atende essa terminologia de pousada, que são diferenciadas dos hotéis pelo porte pequeno e com aparência de ambiente domestico.

Segundo a ABIH (Associação Brasileira de Indústria de Hotéis) e a Embratur definem pousada como sendo "um estabelecimento situado em locais turísticos, fora dos centros urbanos, que recebe pessoas em viagens de recreação e lazer, pode estar instalada ou não em prédio de valor histórico ou com importância regional ou local" (SENAC, 2007. P.07), com uma estrutura administrativa familiar concentrando tratamento personalizado a seus hóspedes já que tem pequeno porte.

Assim, ao apresentar a conceituação de turismo, turismo rural, ecoturismo e fazenda hotel, é possível entender a elaboração do plano de negócios e suas etapas para elaboração de planejamento de implementação de hotel na Fazenda Rancho Grande. 


\subsection{Plano de negócios}

"Um plano de negócios é o guia para a existência da sua empresa,seu mapa rodoviário para avançar pela estrada do sucesso, a planta para construir sua empresa e a chave para abrir a porta para o empréstimo bancário... É o coração do início do seu negócio" (BERLE, 2003. P. 14).

O plano de negócios é o cartão de visita da empresa, é um instrumento de apresentação do negócio em forma concisa, mas que engloba todas as suas principais características. É um documento usado para descrever o negócio.

Segundo a cartilha de Plano de Negócios elaborada pelo SEBRAE (Serviço Brasileiro de Apoio às Micro e Pequenas Empresas):

Plano de negócio é o instrumento ideal para traçar um retrato fiel do mercado, do produto e das atitudes do empreendedor, o que propicia segurança para quem quer iniciar uma empresa com maiores condições de êxito ou mesmo ampliar ou promover inovações em seu negócio (ROSA, 2007. P. 07).

Ao apresentar esse conceito, é possível perceber a importância de se capacitar o empresário ou o interessado em abrir sua empresa investindo na elaboração do planejamento do negócio, pois se trata de um documento que apresenta os objetivos de um negócio e as tomadas de decisões necessárias para que esses objetivos venham a ser alcançados, diminuindo os riscos do negócio.

De acordo com a obra de Olivo,

O plano de negócio é uma oportunidade para o empreendedor refletir e analisar tudo 0 que tem haver com o seu empreendimento. Muitos empresários fracassam por limitar-se a uma visão parcial do negócio. Para elaborá-lo, é necessário refletir sobre três questões: onde estou; aonde quero chegar e como vou chegar lá. É o documento que deve contar com a participação do proprietário e tem como objetivo estruturar as principais idéias, alternativas e ações que deverão ser avaliadas para decidir quanto ao futuro e ao sucesso do empreendimento (OLIVO, 2003. P. 15).

Com esse conceito apresentado por Olivo, é possível observar que o plano de negócio possibilita a avaliação sob os aspectos mercadológico, técnico, tecnológico, financeiro, jurídico e organizacional. Assim, através do plano de negócios é possível detalhar e analisar o projeto de negócio, a estratégia para implementar o projeto, e os recursos necessários.

Segundo Pavani, Deutscher e López, o plano de negócios "é um documento especial, único e vivo que deve refletir a realidade, as perspectivas e a estratégia da empresa, respondendo ao leitor as perguntas quem sou, o que faço, como faço, por que faço, o que quero, e para onde vou" (PAVANI, 2000. P. 11 a 104). 
Esse documento garante no processo de implementação da empresa a organização das idéias e propostas do conjunto das pessoas envolvidas na condução da empresa, a organização da própria empresa, instrumento de comunicação eficiente entre os envolvidos na operação, o comprometimento de todas as pessoas da empresa no caminho que se delineará para ela, a existência de um instrumento de controle gerencial para acompanhamento, avaliação e controle das fases dos projetos da empresa, e a existência de um instrumento eficiente para a captação de recursos, sejam financeiros, humanos ou de parcerias.

O plano de negócios serve como um instrumento de apresentação da empresa para diferentes públicos, portanto, ajuda a encontrar caminhos para o futuro da empresa. Permite elevar a eficiência da gestão e assim, aumentar a qualidade da comunicação, o grau de confiabilidade e melhorar a imagem da empresa.

De acordo com estudo feito na obra de Salim, Hochman, Ramal e Ramal sobre plano de negócios, é possível observar cinco tipos de negócios:

1) Empresa de Prestação de Serviços: é uma empresa cujo objeto de comercialização é um serviço prestado ao cliente, tal como contabilidade, aconselhamento jurídico, conserto de algum equipamento, desenvolvimento de um software, consultoria técnica, etc.

2) Varejo: é aquela em que o fornecedor vende diretamente ao consumidor final em quantidades geralmente pequenas, para seu próprio consumo. Ou seja, a empresa de varejo procura atender a um consumidor que compra para uso próprio. Esse consumidor não repassa a terceiros, como forma de negócio, qualquer parcela da quantidade comprada.

3) Distribuidora: é uma empresa comercial que atua normalmente cobrindo uma área geográfica, na qual é responsável por vender um determinado produto ou conjunto de produtos.

4) Empresa industrial: geralmente fabrica seus produtos utilizando insumos ou produtos elaborados por outros fabricantes para a montagem de seus próprios.

5) Empresa mista: agrega mais de uma das características dos outros tipos de empresa (SALIM, HOCHMAN, RAMAL, RAMAL, 2005. P. 06 a 11).

Ao apresentar esses conceitos de tipos de negócios, identifica-se que a fazenda hotel é uma empresa de prestação de serviços por ter uma estrutura mais simples, que não possui estoques e o custo de venda é embutido no próprio custo do serviço de hospedagem.

Através do plano de negócios é possível planejar e decidir a respeito do futuro da empresa, tem como base o seu passado, sua situação atual em relação ao mercado, aos clientes e à concorrência. Com o plano de negócios é possível identificar os riscos e propor planos para minimizá-los e até mesmo evitá-los; identificar seus pontos fortes e fracos em relação a concorrência e o ambiente de 
negócio em que se atua; conhecer seu mercado e definir estratégias de marketing para seus produtos e serviços; analisar o desempenho financeiro do negócio, avaliar investimentos, retorno sobre o capital investido; enfim, é um poderoso guia que norteará todas as ações da empresa.

O turismo, por ser uma indústria vasta e complexa, deve ter suas principais metas de crescimento programadas e elaboradas por meio de um plano econômico, que pode ser definido como um conjunto específico de metas econômicas quantitativas e qualitativas a serem atingidas em dado período. É uma tentativa de coordenar o processo de decisão econômica a longo prazo, influenciando e controlando o nível de crescimento das principais variáveis econômicas, de forma a alcançar um conjunto de objetivos pré-determinados.

Inovação é uma das palavras mais importantes para o empreendedor dos dias atuais, ele transforma uma oportunidade em negócio. Essa transformação é feita por meio do plano de negócios, e a empresa a ser criada é a forma de materialização dessa oportunidade.

Para que a empresa venha a ser uma empresa de sucesso é necessário uma boa idéia e um plano de negócios para que essa idéia possa ser transformada em um bom negócio. Mas só o plano não é suficiente para que a empresa tenha sucesso, é necessária uma boa gerência e uma equipe dedicada e capacitada para exercer suas funções.

Para se entender de fato o que é o plano de negócios e a sua importância, é necessário se compreender alguns conceitos:

\subsubsection{Planejamento}

Segundo Barreto, "o planejamento é uma atividade, não é algo estático, é um devir, um acontecer de muitos fatores concomitantes que têm que ser coordenados para se alcançar um objetivo que está em outro tempo" (BARRETTO, 2003. P. 12).

Esse conceito apresenta a importância do planejamento para a implementação do turismo, podendo ser utilizado como uma técnica para tomadas de decisões, pois nesse processo são mostrados os potenciais turísticos da localidade em estudo, aqui a Fazenda Rancho Grande. 
Para que haja um desenvolvimento equilibrado do turismo, um turismo que ocorra em harmonia com os recursos naturais, culturais e sociais das regiões turísticas preservando, assim, para gerações futuras, o planejamento torna-se indispensável, pois equilibra o fluxo desordenado de turistas, evita danos ambientais, mantendo a atratividade dos recursos turísticos naturais e culturais, além de contribuir para 0 desenvolvimento da atividade turística sem prejudicar suas próprias fontes de existência.

Planejar é saber conhecer os fatos, saber observar, ser objetivo, ter domínio dos métodos de pesquisa, ser paciente e tolerante ao checar hipóteses e saber admitir possíveis erros para serem bem administrados.

O planejamento turístico é orientado pelos seguintes princípios, segundo Barretto:

Da inerência: o planejamento é indispensável; da universalidade: o planejamento tenta prever todas as variáveis e todas as conseqüências, até onde seja possível, levando em conta as opiniões [...]; da unidade: o planejamento abrange múltiplas facetas, que devem ser integradas num conjunto coerente; da previsão: o planejamento é intrinsecamente previsão; da participação: o planejamento requer a participação de todos os níveis e setores da administração [...] (BARRETTO, 2003. P. 14).

Ao apresentar o conceito elaborado por Barretto, observou-se que o planejamento tem quatro dimensões: a racional, política, valorativa e técnico-administrativa. Essas dimensões são necessárias e estão presentes ao mesmo tempo, pois não se deve apenas pensar no lado formal quando se está planejando, mas também no lado racional e no valorativo.

A dimensão racional é o esforço mental de criatividade e reflexão, é um repensar permanente, está vinculada a operações de reflexão, decisão, ação e revisão. A dimensão política é o poder de decisão para aplicação do projeto. A dimensão técnico-administrativa define as funções e delegação de autoridades, "ou seja, definir objetivos, recursos, pessoal e tempo" (BARRETTO, 2003. P. 16). A dimensão valorativa "implica o conhecimento profundo da realidade na qual o planejamento está inserido e a projeção das conseqüências sociais da ação" (BARRETTO, 2003. P. 16).

Ansarah percebe o planejamento com os seguintes objetivos:

[...] é necessário planejar a estruturação dos serviços e equipamentos oferecidos, prever as necessidades e desejos do turista, estudar a capacidade de carga turística (carrying capacity) de recursos e/ou localidades, integrar a população local à nova realidade, antever as necessidades de preservação ambiental e exercê-la, determinar estratégias de treinamento pessoal, estimar lucros e 
despesas, observar a adequação de todos esses procedimentos às leis vigentes, etc (ANSARAH, 2001. P. 71).

Ao apresentar o conceito de Ansarah, observa-se a necessidade da elaboração de um planejamento para atender as necessidades de preservação e implementação do negócio na propriedade.

Existem vários níveis de planejamento. Porém, todos devem ser capazes de responder aos questionamentos: o quê, quando, como, e onde. Seja no nível estratégico, tático ou operacional.

\subsubsection{Planejamento estratégico}

O planejamento estratégico é o processo que realmente mobiliza as pessoas e a empresa para construir e escolher que tipo de futuro deseja, exigindo que sejam levados em consideração quatro componentes fundamentais de uma boa estratégia: clientes, fornecedores, concorrentes e empresa.

O conceito de planejamento estratégico tem-se tornado excepcionalmente importante nos círculos empresariais de hoje, em grande parte devido à crescente complexidade dos ambientes tanto internos como externos, assim como à sofisticação cada vez maior da administração.

De acordo com a obra de Salim, Hochman, Ramal e Ramal:

O Planejamento estratégico está associado a uma linha de atuação que visa atingir objetivos de longo prazo. Ele define qual o negócio da empresa, onde esta está hoje e onde quer chegar. Para isso, fixa macrobjetivos que necessitam ser detalhados e compatibilizados com as possibilidades a cada ponto de sua execução (SALIM, 2005. P. 17).

O planejamento estratégico inclui atividades que envolvem a definição da missão da organização, o estabelecimento de seus objetivos e o desenvolvimento de estratégias que possibilitem o sucesso das operações no seu ambiente.

Oliveira destaca o seguinte conceito:

planejamento estratégico é o processo administrativo que proporciona sustentação metodológica para se estabelecer a melhor direção a ser seguida pela empresa, visando ao otimizado grau de interação com os fatores externos não controláveis - e atuando de forma inovadora e diferenciada (OLIVEIRA, 2007. P. 17).

Para esse trabalho de conclusão de especialização será utilizado o conceito de Oliveira por ser um conceito que valoriza a interação dos fatores internos e externos do empreendimento. 
O planejamento estratégico pressupõe a necessidade de um processo de tomada de decisão que deve ocorrer antes, durante e depois de sua elaboração e implementação na empresa. Deve conter componentes individuais e organizacionais, e ações orientadas para a garantia de que todos os interesses alocados no ambiente da empresa sejam absorvidos.

É possível perceber que o planejamento estratégico considera a empresa como um todo, esse é um aspecto importante para o entendimento das fases do planejamento estratégico (avaliação estratégica, definição das prioridades, programação das ações, e monitoração).

Esse tipo de planejamento costuma ser de responsabilidade dos níveis mais altos da empresa e diz respeito à formulação de objetivos e à seleção dos cursos de ação que serão seguidos para sua consecução, observando as condições externas e internas da empresa e sua evolução esperada.

Por meio do planejamento estratégico, a empresa espera conhecer melhor seus pontos fortes, conhecer e eliminar ou adequar seus pontos fracos, conhecer e usufruir as oportunidades externas, conhecer e evitar as ameaças externas, e ter um efetivo plano de trabalho.

Esse tipo de planejamento não existe em um vácuo, mas deve levar em consideração as variáveis que afetam a organização. Assim sendo, para haver um planejamento estratégico eficaz é essencial identificar as principais variáveis, estar ciente de seu impacto, ser capaz de prever seu impacto potencial futuro.

O planejamento estratégico se diferencia de outros tipos de planejamento organizacional segundo os seguintes critérios: envolve decisões tomadas pela alta administração; envolve apropriação de muitos recursos, como dinheiro, mão-deobra ou capacidade física; tem impacto significativo a longo prazo; e, focaliza a interação da organização com o ambiente externo.

\subsubsection{Planejamento tático}

De acordo com a obra de Oliveira, é possível observar que "o planejamento tático tem por objetivo otimizar determinada área de resultado e não a empresa como um todo. Portanto, trabalha com decomposições dos objetivos, estratégias e políticas 
no planejamento estratégico" (OLIVEIRA, 2007. P. 18). Esse conceito abrange o planejamento tático como um todo.

Na obra de Chiavenato, o planejamento tático é definido como o;

planejamento focado no médio prazo e que enfatiza as atividades correntes das várias unidades ou departamentos da organização. [...] O administrador utiliza o planejamento tático para delinear o que as várias partes da organização, como departamentos ou divisões, devem fazer para que a organização alcance sucesso no decorrer do período de um ano de seu exercício (CHIAVENATO, 2008. P. 418).

Esse tipo de planejamento é desenvolvido em níveis organizacionais intermediários, ou seja, é realizado no nível gerencial ou departamental, tendo como principal finalidade a utilização eficiente dos recursos disponíveis para a execução de objetivos previamente fixados, segundo uma estratégia predeterminada, bem como as políticas orientativas para o processo decisório da empresa.

Ainda na obra de Chiavenato, é possível observar que os planos táticos geralmente envolvem:

1. Plano de produção: envolvendo métodos e tecnologias necessárias para as pessoas em seu trabalho, arranjo físico do trabalho e equipamentos como suportes para as atividades e tarefas.

2. Planos financeiros: envolvendo captação e aplicação do dinheiro necessário para suportar as várias operações da organização.

3. Planos de marketing: envolvendo os requisitos de vender e distribuir bens e serviços no mercado e atender ao cliente.

4. Plano de recursos humanos: envolvendo recrutamento, seleção e treinamento das pessoas nas várias atividades dentro da organização. Recentemente, as organizações estão também se preocupando com a aquisição de competências essenciais para o negócio através da gestão do conhecimento corporativo (CHIAVENATO, 2008. P. 418).

Ao apresentar esse conceito, é possível perceber a realização do planejamento tático de forma departamental. Após a realização desse planejamento, deve-se elaborar o planejamento operacional, apresentado a seguir.

\subsubsection{Planejamento operacional}

Segundo Salim, Hochman, Ramal e Ramal:

O planejamento operacional é parte do planejamento estratégico e detalha cada um de seus macrobjetivos em metas (normalmente definidas em termos de número) e em plano para alcançar essas metas. Geralmente tem horizonte de curto prazo e é muito sensível às variações de cenários do ambiente. Costuma orientar o dia-a-dia da empresa, mas sempre vinculado ao planejamento estratégico (SALIM, HOCHMAN, RAMAL, RAMAL, 2005. P. 17). 
Esse conceito apresenta a necessidade de se traçar objetivos e criar metas para a realização do planejamento.

Oliveira define o planejamento operacional "como a formalização, principalmente através de documentos escritos, das metodologias de desenvolvimento e implantação estabelecidas. Portanto, nesta situação tem-se, basicamente, os planos de ação ou planos operacionais" (OLIVEIRA, 2007. P. 19).

Esse tipo de planejamento deve conter os recursos necessários para seu desenvolvimento e implantação, os procedimentos básicos a serem adotados, os resultados finais esperados, os prazos estabelecidos, e os responsáveis por sua execução e implantação.

O planejamento operacional corresponde a um conjunto de partes homogêneas do planejamento tático.

\subsection{Etapas do plano de negócios:}

O plano de negócios é composto por várias seções que se relacionam e permitem um entendimento global do negócio de forma escrita, porém foi dado maior ênfase ao plano financeiro por se tratar de tema essencial desse trabalho de conclusão de especialização. As etapas são apresentadas como seguem:

\subsubsection{Sumário executivo:}

O sumário executivo é a parte mais importante do plano de negócios, pois deve motivar o leitor a levar em consideração o plano todo. É nele onde se reúne todas as idéias e planejamentos, transforma as partes soltas da empresa em um todo, e resume tudo o que está propondo.

O sumário executivo permite ao leitor entender de uma maneira rápida o conceito básico e os pontos mais importantes da empresa.

Trata-se de um resumo introdutório dos principais pontos do plano de marketing que demonstram sinteticamente os objetivos, as estratégias e os resultados esperados.

\subsubsection{Análise de mercado:}


$\mathrm{Na}$ análise de mercado, deve-se mostrar que se conhece muito bem o mercado consumidor do seu produto/serviço (através de pesquisas de mercado): como está segmentado, as características do consumidor, análise da concorrência, a sua participação de mercado e a dos principais concorrentes, os riscos do negócio.

\subsubsection{Plano de marketing:}

Segundo Dolabella, "marketing é o processo de planejamento de uma organização que busca realizar trocas com o cliente, cada um com interesses específicos: o cliente quer satisfazer suas necessidades; uma empresa quer gerar receita" (DOLABELA, 2006. P. 147).

As atividades desenvolvidas de marketing são, basicamente, divididas em quatro áreas, como pode ser observado na obra de Dolabella:

Análise - consiste em compreender as forcas que atuam no mercado em que a empresa opera ou pretende operar no futuro. É um processo contínuo de investigação das condições que determinam a localização, a natureza, o tamanho, a direção e a intensidade daquelas forcas vigentes no mercado que interessam comercialmente à empresa. É a busca e processamento sistemático de informações para reduzir os riscos das decisões [...];

Adaptação - é a atividade responsável pelo ajuste da oferta da empresa - ou seja, as suas linhas de produtos/serviços - às forças externas detectadas através da análise, isto é, às necessidades do cliente [...];

Ativação - é o conjunto de medidas destinadas a fazer com que o produto atinja os mercados pré-definidos e seja adquirido pelos compradores, com a freqüência desejada [...];

Avaliação - atividade que se propõe a exercer controles sobre os processos de comercialização e de interpretação dos resultados, a fim de racionalizar os futuros processos de marketing. Nela existe uma preocupação continua em melhorar a relação custo/benefício das atividades sob seu controle [...] (DOLABELA, 2006. P. 147).

As funções de análise e avaliação, são funções de apoio às outras duas funções, operam com o levantamento e a interpretação de informações provenientes do mercado, que são denominados composto de marketing. O composto de marketing contém quatro elementos que devem ser administrados pela organização: produto (o que vender); preço (quanto custa); promoção (como vender); e, praça (onde vender e como distribuir o produto).

O plano de marketing é constituído pela análise de mercado e pela estratégia de marketing. A análise de mercado apresenta todas as informações necessárias sobre os clientes, os fornecedores, os concorrentes e do ambiente em que a empresa irá atuar, para verificar a viabilidade do negócio. A estratégia de marketing 
que constitui o planejamento da forma como será oferecido os produtos da empresa ao mercado visando a otimização de suas potencialidades.

Esse plano é basicamente um planejamento do composto de marketing da organização, é com um mapa que apresenta à empresa por onde está indo e aonde quer chegar. Deve identificar as oportunidades de negócios e como entrar no mercado em que irá atuar. No plano de marketing são estabelecidos os objetivos da empresa e a escolha de estratégias viáveis para que esses objetivos sejam atingidos.

\subsubsection{Plano operacional:}

O plano operacional diz respeito à descrição do fluxo operacional do empreendimento, ou seja, do caminho percorrido desde a aquisição da matériaprima até o produto pronto chegar ao consumidor. Pode incluir detalhes da cadeia de suprimentos, controle de qualidade, logística e sistemas de gestão.

Esta seção deve apresentar as ações que a empresa está planejando em seu sistema produtivo, indicando o impacto que estas ações terão em seus parâmetros de avaliação de produção. Deve conter informações operacionais atuais e previstas de fatores como: lead time do produto ou serviço, percentual de entregas a tempo (on time delivery), rotatividade do inventário, índice de refugo, lead time de desenvolvimento de produto ou serviço.

Um Plano Operacional é, normalmente, um plano interno, e pode também ser chamado de plano interno ou plano anual. Normalmente, será mais detalhado no que diz respeito à implementação de objetivos, datas, deadlines e responsabilidades das equipas e dos gerentes. Poderá incluir detalhes e definições de ordem técnica, em função da especificidade de cada negócio.

Embora pareça fácil, o processo produtivo - seja de produtos ou de serviços - é bastante difícil e complexo, exigindo muito planejamento e controle da empresa. $\mathrm{O}$ planejamento cuidadoso do plano operacional pode evitar uma série de problemas em relação às instalações da empresa, máquinas e equipamentos e em relação aos estoques necessários aos sistemas produtivos de comercialização e de outros serviços. Além destas preocupações, a empresa deve planejar e definir todo o 
sistema produtivo, ou seja, todo o fluxo da produção/serviços, desde o primeiro contato com o cliente até a satisfação plena das suas necessidades.

Para que a empresa possa ser efetivamente operacionalizada, a mesma precisa analisar e decidir sobre aspectos técnicos do seu negócio, e dentre eles, os mais importantes e que devem ser estudados no plano de negócios são: a localização da empresa, as instalações de produção e o layout da empresa, o sistema de produção e o processo de melhorias do sistema de produção, a política e o sistema de compras, o controle de qualidade e o impacto ambiental.

\subsubsection{Plano financeiro:}

Em tempos de economia global, onde cada vez mais o amadorismo e o improviso estão desaparecendo é indispensável a presença de um planejamento e de inovações no processo de gestão empresarial. A empresa que deseja permanecer e ampliar seu mercado tem que estar preparada para desafios, e um dos fatores responsáveis para a obtenção do sucesso empresarial, é o processo de planejamento financeiro.

Para entender melhor o plano financeiro, Lucion define o que é planejamento e o que é financeiro:

A expressão planejamento tem em seu significado literal o ato ou efeito de
planejar; trabalho de preparação para qualquer empreendimento, segundo
roteiro e métodos determinados; planificação, processo que leva ao
estabelecimento de um conjunto coordenado de ações (pelo governo, pela
direção de uma empresa, etc.) visando à consecução de determinados objetivos;
elaboração de planos ou programas governamentais, especialmente na área
econômica e social. Já financeiro dignifica, relativo às finanças, à circulação e
gestão do dinheiro e de outros recursos líquidos. Contudo, o conceito de
planejamento financeiro tem-se a junção desses dois conceitos levados para um
plano empresarial (LUCION, 2005. P. 144). Assim, de acordo com Lucion, o planejamento financeiro das empresas "visa dar sustentação necessária para execução de planos estratégicos a curto e a longo prazo, direcionando toda a ação empresarial com vistas a atingir as metas orçamentárias previstas" (LUCION, 2005. P. 143).

O plano financeiro deve apresentar como a empresa se comportará ao longo do tempo do ponto de vista financeiro, descrições e cenários, pressupostos críticos, situação histórica, fluxo de caixa, análise do investimento, demonstrativo de resultados, projeções de balanços e outros indicadores. 
Ele deve ser cuidadosamente montado e calculado, tentando apresentar principalmente quais serão os investimento necessários, média dos custos, média da receita, entre outras informações que possam ajudar ao empreendedor definir e analisar o cenário onde ele se encontra.

Segundo Teló, "o planejamento financeiro estabelece o modo pelo qual os objetivos financeiros podem ser alcançados. Um plano financeiro é, portanto, uma declaração do que deve ser feito no futuro" (TELÓ, 2001. P. 21). Assim, o planejamento financeiro é uma parte importante do trabalho do administrador. Definindo os planos financeiros e orçamentos ele estará fornecendo roteiros para atingir objetivos da empresa. Além disso, esses instrumentos oferecem uma estrutura para coordenar as diversas atividades da empresa e atuam como mecanismos de controle, estabelecendo um padrão de desempenho contra o qual é possível avaliar os eventos reais.

Ao iniciar a elaboração do planejamento financeiro de um novo negócio, é importante determinar inicialmente o montante de recursos necessários para que o negócio inicie bem suas atividades e se mantenha nos primeiros anos, e como será possível conseguir este montante. O primeiro interesse então é fixar a atenção nos investimentos iniciais, ou seja, no dinheiro necessário para abrir o negócio e mantêlo funcionando por um determinado tempo, até que o mesmo caminhe por seus próprios recursos.

Baseado na obra de Teló (2001), apresenta-se a estrutura do plano financeiro:

a) Investimento inicial: especifica-se neste item os custos para as instalações, suprimentos, equipamentos e mobiliário necessários para a implantação do negócio. Estas especificações ajudarão no levantamento do investimento fixo - ativo permanente - necessário para implantação da empresa. Mesmo que a empresa seja instalada (ou pretenda se instalar) em uma incubadora, que comumente oferece parte desta estrutura inicial, estes valores devem ser considerados.

b) Receitas: a projeção das vendas esperadas para o horizonte de cinco anos, juntamente com a determinação do preço a ser praticado pelo serviço, poderá ser visualizada as vendas em termos de valores, denominadas de receitas. 
c) Custos e despesas: deverão ser levantados todos os valores que serão despendidos para a execução do serviço que a empresa está se propondo; deverão ser levantados tanto os custos de produção, quanto as despesas relativas ao suporte à produção como à administração, vendas, etc. Estas despesas poderão ser denominadas de fixas ou variáveis. A diferenciação entre ambas é a sua relação direta com o volume de vendas ou não, isto é, as despesas variáveis irão sofrer acréscimos (ou decréscimos) proporcionalmente ao aumento (redução) do volume vendido, enquanto que as fixas poderão ter aumentos também, mas não diretamente proporcionais à vendas.

d) Fluxo de caixa: é um instrumento que tem como objetivo básico, a projeção das entradas (receitas) e saídas (custos, despesas e investimentos) de recursos financeiros por um determinado período de tempo. Com o fluxo de caixa, o empreendedor terá condições de identificar se haverá excedentes ou escassez de caixa durante o período em questão, de modo que este constitui um importante instrumento de apoio ao planejamento da empresa (especialmente na determinação de objetivos e estratégias). A partir das informações levantadas nos itens anteriores, juntamente com investimentos adicionais que porventura venham a ser feitos e retirando-se itens não monetários, o fluxo de caixa pode ser montado.

e) Demonstrativo de resultados / lucratividade prevista: com base nos valores já identificados, relativos às entradas e saídas da empresa, o empreendedor poderá utilizar uma planilha para elaborar o "Demonstrativo de resultados" e chagar a lucratividade de seu negócio. A partir disso, terá condições de apurar informações cruciais como o retorno que terá sobre o capital investido na empresa e o prazo de retorno sobre o investimento inicial. Isto é fundamental para que se avalie o grau de atratividade do empreendimento.

f) Ponto de equilíbrio: o cálculo do ponto de equilíbrio ajuda o empreendedor a encontrar qual o nível de vendas em que a receita será igual a todas as saídas de caixa da empresa. Isto é importante porque indica qual o nível mínimo de vendas que a empresa deverá manter para que não opere com prejuízo. 
g) Payback: é uma das técnicas de análise de investimento mais comuns que existem, pois Consiste em umas das alternativas mais populares ao VPL. Sua principal vantagem em relação ao VPL consiste em que a regra do payback leva em conta o tempo do investimento e conseqüentemente é uma metodologia mais apropriada para ambientes com risco elevado. Este método visa calcular o número de períodos ou quanto tempo o investidor irá precisar para recuperar o investimento realizado. Um investimento significa uma saída imediata de dinheiro. Em contrapartida se espera receber fluxos de caixa que visem recuperar essa saída. O payback calcula quanto tempo isso irá demorar.

h) Valor presente líquido (VPL): também conhecido como método do valor atual ou valor atual líquido, é a fórmula matemático-financeira de se determinar o valor presente de pagamentos futuros descontados a uma taxa de juros apropriada, menos o custo do investimento inicial. Basicamente, é o calculo de quanto os futuros pagamentos somados a um custo inicial estaria valendo atualmente.

i) Taxa interna de retorno (TIR): é a taxa de desconto que iguala o valor atual líquido dos fluxos de caixa de um projeto a zero; ou seja, é a taxa que, com o valor atual das entradas, seja igual ao valor atual das saídas. Para fins de decisão, a taxa obtida deverá ser confrontada à taxa que representa o custo de capital da empresa e o projeto só deverá ser aceito quando a sua taxa interna de retorno superar o custo de capital, significando que as aplicações da empresa estarão rendendo mais que o custo dos recursos usados na entidade como um todo.

É essencial ter um bom conhecimento do negócio para uma análise das políticas de investimento e financiamento. O planejamento financeiro torna-se um instrumento indispensável para a estratégia empresarial fornecendo um referencial técnico para os executivos tomarem decisões que acarretam no crescimento em uma empresa.

Para se entender melhor o tipo de negócio, deve ser verificado o inventário turístico - Capítulo 4, realizado em 2008 pelos proprietários como início desse projeto de implementação da fazenda hotel na propriedade. 


\section{MÉTODOS E TÉCNICAS DE PESQUISA}

A necessidade de conhecimentos sobre turismo que apóiem as decisões, em seus diferentes setores de atuação, é de fundamental importância para os profissionais e pesquisadores da área, que procuram proceder conforme regras genéricas, aceitas por quase todas as ciências, e é nesse sentido que podemos dizer que existe um método científico.

Na obra de Lakatos e Marconi, define-se método como "o conjunto das atividades sistemáticas e racionais que, com maior segurança e economia, permite alcançar o objetivo - conhecimentos válidos e verdadeiros -, traçando o caminho a ser seguido, detectando erros e auxiliando as decisões do cientista" (LAKATOS, MARCONI, 2001. P. 83).

A metodologia científica estuda os métodos e processos utilizados para a obtenção e o desenvolvimento do conhecimento científico, estuda como se faz ciência.

Dencker define metodologia como "a maneira concreta como se realiza a busca de conhecimento, e o que fazemos para adquirir o conhecimento desejado de maneira racional e eficiente" (DENCKER, 2002. P. 18); e ciência como "uma forma especial de conhecimento da realidade empírica, e um conhecimento racional, metódico e sistemático, capaz de ser submetido à verificação" (DENCKER, 2002. P. 18).

Assim, a ciência busca o conhecimento sistemático do universo. A maneira como se adquirir conhecimento ao observar a realidade, ou experimentar novas formas de agir ou interpretar os fatos de diferentes formas é a metodologia.

Considerando os conceitos anteriores, o presente trabalho seguiu o seguinte critério metodológico:

\subsection{Tipo de pesquisa quanto aos objetivos}

Dencker, em sua obra, classifica pesquisa quanto aos objetivos da seguinte forma:

a) Pesquisa exploratória: "procura aprimorar idéias ou descobrir intuições. Caracteriza-se por possuir um planejamento flexível envolvendo em geral 
levantamento bibliográfico, entrevistas com pessoas experientes e análise de exemplos similares" (DENCKER, 2002. P. 124);

b) Pesquisa descritiva: "procura descrever fenômenos ou estabelecer relações entre variáveis. Utiliza técnicas padronizadas de coleta de dados como 0 questionário e a observação sistemática" (DENCKER, 2002. P. 124).

c) Pesquisa explicativa: "procura identificar os fatores que determinam ou contribuem para a ocorrência dos fenômenos. Caracteriza-se pela utilização do método experimental (nas ciências físicas) e observacional (nas ciências sociais)" (DENCKER, 2002. P. 125).

Essa pesquisa foi exploratória, pois formula um problema, levantando hipóteses, identificação e operacionalização das variáveis para elaboração do plano financeiro.

\subsection{Pesquisa quanto aos procedimentos técnicos}

De acordo com o procedimento de coleta de dados, segundo Dencker, a pesquisa pode ser:

a) Pesquisa bibliográfica: "desenvolvida a partir de material já elaborado: livros e artigos científicos. [...] toda pesquisa requer uma fase de levantamento e revisão da literatura existente para elaboração conceitual e definição dos marcos teóricos. [...] possibilita o levantamento de dados históricos" (DENCKER, 2002. P. 125).

b) Pesquisa documental: utiliza "material que ainda não recebeu tratamento analítico ou que pode ser reelaborado. [...] podem ser documentos de primeira mão conservados em arquivos de instituições públicas e privadas. [...] documentos de segunda mão: relatórios e dados estatísticos" (DENCKER, 2002. P. 125).

c) Pesquisa experimental: "consiste em verificar as alterações causadas por uma determinada variável no objeto escolhido para estudo" (DENCKER, 2002. P. 126).

d) Pesquisa ex-post-facto: "se baseia nos princípios da pesquisa experimental, com a diferença que o pesquisador não tem controle sobre as variáveis.Comparam-se dois grupos basicamente semelhantes atribuindo-se as diferenças existentes entre eles a um fator identificado em apenas um deles" (DENCKER; 2002. P. 126). 
e) Levantamento: "consiste na coleta de dados referentes a uma dada população a partir de uma amostra selecionada dentro de critérios estatísticos. As conclusões obtidas com a amostra são projetadas para o universo" (DENCKER, 2002. P. 127).

f) Estudo de caso: "é o estudo profundo e exaustivo de determinados objetos ou situações. Permite o conhecimento em profundidade dos processos e relações sociais" (DENCKER, 2002. P. 127).

g) Pesquisa ação: "pesquisa empírica com estreita vinculação com uma ação ou resolução de um problema coletivo. Os pesquisadores e participantes representativos da situação ou do problema estão envolvidos de modo cooperativo ou participativo" (DENCKER, 2002. P. 127).

h) Pesquisa participante: "pesquisa realizada mediante a integração do pesquisador, que assume a função no grupo a ser pesquisado, mas sem obedecer a uma proposta predeterminada de ação. O objetivo é obter conhecimento mais profundo do grupo" (DENCKER; 2002. P. 128).

Para esse trabalho de conclusão de especialização, os procedimentos de coleta de dados adotados foram a pesquisa bibliográfica, pois houve um estudo de livros e artigos relacionados à área em estudo; e, pesquisa documental, pois houve uma análise de documentos e registros públicos para o estudo da propriedade Fazenda Rancho Grande, Formosa/GO.

\subsection{Técnicas de pesquisa}

Lakatos e Marconi definem técnica como "um conjunto de preceitos ou processos de que se serve uma ciência ou arte; é a habilidade para usar esses preceitos ou normas, a parte prática" (LAKATOS, 2001. P. 174).

$\mathrm{Na}$ obra de Fachin, pesquisa "é um procedimento intelectual para adquirir conhecimentos pela investigação de uma realidade e busca de novas verdades sobre um fato (objeto, problema)" (FACHIN, 2002. P. 49).

Dessa forma, as técnicas de pesquisa podem ser:

a) Pesquisa documental: a fonte de coleta de dados está restrita a documentos. "É toda informação de forma oral, escrita ou visualizada. A pesquisa documental consiste na coleta, classificação, seleção difusa e na utilização de toda espécie de 
informações, compreendendo também as técnicas e métodos que facilitam a sua busca e a sua identificação" (FACHIN, 2002. P. 152).

b) Pesquisa bibliográfica: abrange toda bibliografia já tornada pública em relação ao tema de estudo. "A pesquisa bibliográfica diz respeito ao conjunto de conhecimentos humanos reunidos nas obras. Tem como base fundamental conduzir o leitor a determinado assunto e a produção, coleção, armazenamento, reprodução, utilização e comunicação das informações coletadas para o desempenho da pesquisa" (FACHIN, 2002. P. 125).

c) Pesquisa de campo: "se detém na observação do contexto no qual é detectado um fato social (problema), que a princípio passa a ser examinado e, posteriormente, é encaminhado para explicações por meio dos métodos e das técnicas específicas" (FACHIN, 2002. P. 133).

d) Pesquisa de laboratório: "tem a propriedade de permitir ao pesquisador a manipulação das variáveis independentes. [...] é realizada, geralmente, em recinto fechado e com instrumentos próprios. Ela cria o contexto do objeto, ao mesmo tempo que provoca os fenômenos e os observa" (FACHIN, 2002. P. 132).

Aqui, foram utilizadas as pesquisas bibliográfica e documental, pois houve uma busca de informações em livros, artigos, periódicos e documentos públicos.

\subsection{Coleta de dados}

A metodologia é a maneira concreta de realizar a busca do conhecimento, o método é mais geral e abrangente e estabelece o que fazer enquanto as técnicas são o como fazer. Conforme as técnicas utilizadas, as pesquisas podem ser classificadas de diferentes maneiras:

a) Entrevista: "é uma comunicação verbal entre duas ou mais pessoas, com um grau de estruturação previamente definido, cuja finalidade é a obtenção de informações de pesquisa" (DENCKER, 2002. P. 137).

b) Questionários: é a obtenção, "de maneira sistemática e ordenada, de informações sobre as variáveis que intervêm em uma investigação, em relação a uma população ou amostra determinada" (DENCKER, 2002. P. 146).

Essas duas técnicas apresentadas foram utilizadas para construção desse trabalho de conclusão de curso. Foi feita uma entrevista com o proprietário da fazenda para 
conhecer a história da propriedade (apêndice A - memorial descritivo), além de ter sido aplicado um questionário com o mesmo para obter informações técnicas da propriedade (anexo II - questionário).

\subsection{Universo de pesquisa}

Para esse projeto de implementação de hotel na Fazenda Rancho Grande, foram analisados o setor de turismo rural da cidade de Formosa.

A seleção dos elementos que vão compor o universo de pesquisa deve ser feita por uma metodologia adequada. Essa metodologia pode ser:

a) Amostragem aleatória simples: "consiste em escolher uma amostra de uma população, tal que qualquer item da população tenha a mesma probabilidade de ser selecionado" (RIBEIRO JÚNIOR, 209).

b) Amostragem sistemática: "a amostra sistemática apresenta características parecidas com a amostra aleatória simples, porém por um processo mais rápido e mais simples" (RIBEIRO JÚNIOR, 2009).

c) Amostragem aleatória estratificada: "quando a população for heterogênea [...] deve-se dividir a população em subpopulações de forma que dentro das subpopulações haja homogeneidade" (RIBEIRO JÚNIOR, 2009).

Nesse trabalho, foi utilizada a técnica de amostragem sistemática pois a concorrência foi analisada especificamente sob aspectos de qualidade e demanda de serviços 


\section{DESCRIÇÃO DA ORGANIZAÇÃO PESQUISADA}

Nesse capítulo há uma preocupação em mostrar uma nova visão para estruturar um inventário turístico no meio rural, proposta por Salles (2006). Um dos objetivos desse inventário é divulgar os elementos de qualificação e quantificação dos equipamentos e da infra-estrutura turística da Fazenda Rancho Grande, objeto de estudo desse trabalho de conclusão de especialização.

Segundo Stigliano e Bittencout César "inventário turístico é a elaboração de uma lista detalhada de todas as estruturas, serviços, equipamentos e atrativos relacionados à localidade de interesse do planejamento turístico" (STICLIANO, BITTENCOURT CÉSAR, 2005. P. 05). É o primeiro passo para a elaboração de um plano de desenvolvimento de turismo.

Segundo a Embratur, inventário turístico "é o levantamento do conjunto dos recursos turísticos de uma determinada região, visando a correta ordenação e exploração do território, de forma a otimizar a utilização de seus recursos naturais e da oferta turística em geral" (EMBRATUR, 2009).

Necessita-se da elaboração desse inventário para nortear $\circ$ projeto de implementação da fazenda hotel e da infra-estrutura necessária. Esse é o primeiro passo para elaboração do plano de desenvolvimento de turismo na Fazenda Rancho Grande, que consiste em caracterizá-la. A próxima etapa é aplicar as técnicas de ações de marketing, a análise SWOT (Strengh, Weakness, Opportunities and Threats - Ameaça, Oportunidade, Ponto Fraco e Ponto Forte), metodologia escolhida para a análise da demanda, reflexão sobre concorrentes, elaboração do diagnóstico, prognóstico e proposições de ação.

A análise SWOT é uma pesquisa comparativa e competitiva, como pode ser observado na obra de Cooper:

A análise de mercado também deve incorporar um estudo de evoluções em mercados competitivos e/ou em modalidades competitivas de transporte. Geralmente, estas questões serão tratadas em um estudo de vantagem competitiva e comparativa que incorpore uma análise dos pontos fortes, pontos fracos, oportunidades e ameaças (análise SWOT) (COOPER, 2001. 246).

O inventário é composto por um planejamento de marketing que faz a análise SWOT, método para análise dos pontos positivos, negativos, oportunidades e ameaças do objeto em estudo. Essa metodologia é aconselhada para que se possa 
continuar o estudo de implementação do turismo rural e ecoturismo na Fazenda Rancho Grande.

A proposta de metodologia escolhida para esse projeto foi a de Salles, pois pretende introduzir uma nova metodologia para a elaboração de inventário turístico no meio rural, um roteiro dinâmico com algumas evoluções no conhecimento. $O$ autor divide o inventário em macrolocalidade, microlocalidade, área rural e atividades turísticas em desenvolvimentos. Além desses pontos propostos por Salles, é apresentado um memorial descritivo da propriedade para que possa perceber o potencial turístico da localidade.

\subsection{Macrolocalidade}

A macrolocalidade é uma avaliação da realidade geográfica da propriedade através da cartografia apresentando as formas, acidentes físicos, clima, produções, populações e divisões políticas da propriedade, além de mostrar a proximidade de vilas ou povoados e vias de acessos e suas características.

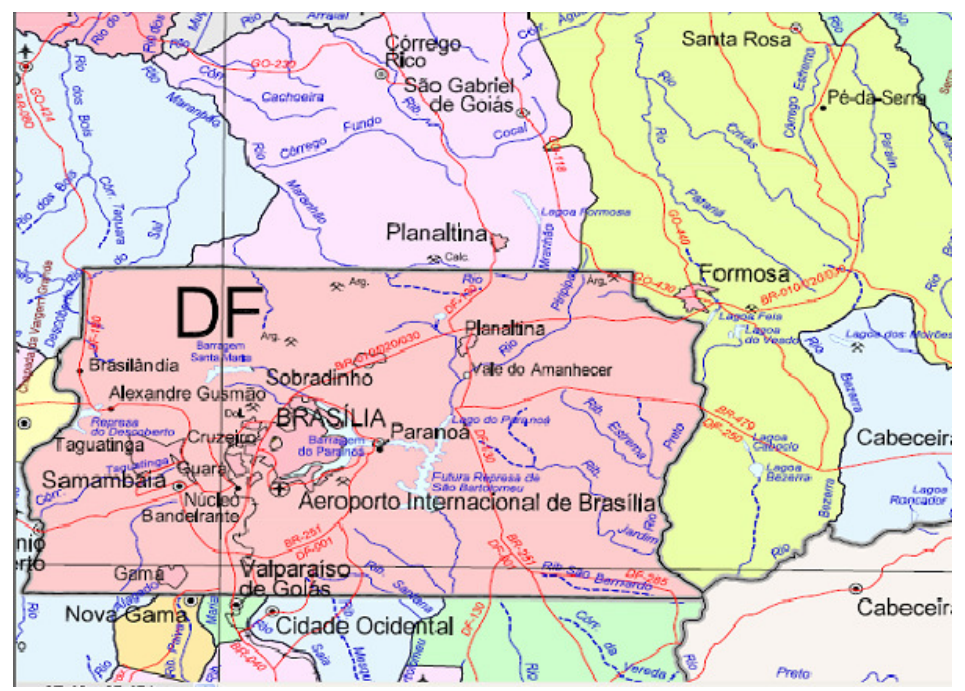

Mapa 1. Mapa geográfico da região de Formosa - GO e DF (ADA INTERNET, 2009). 


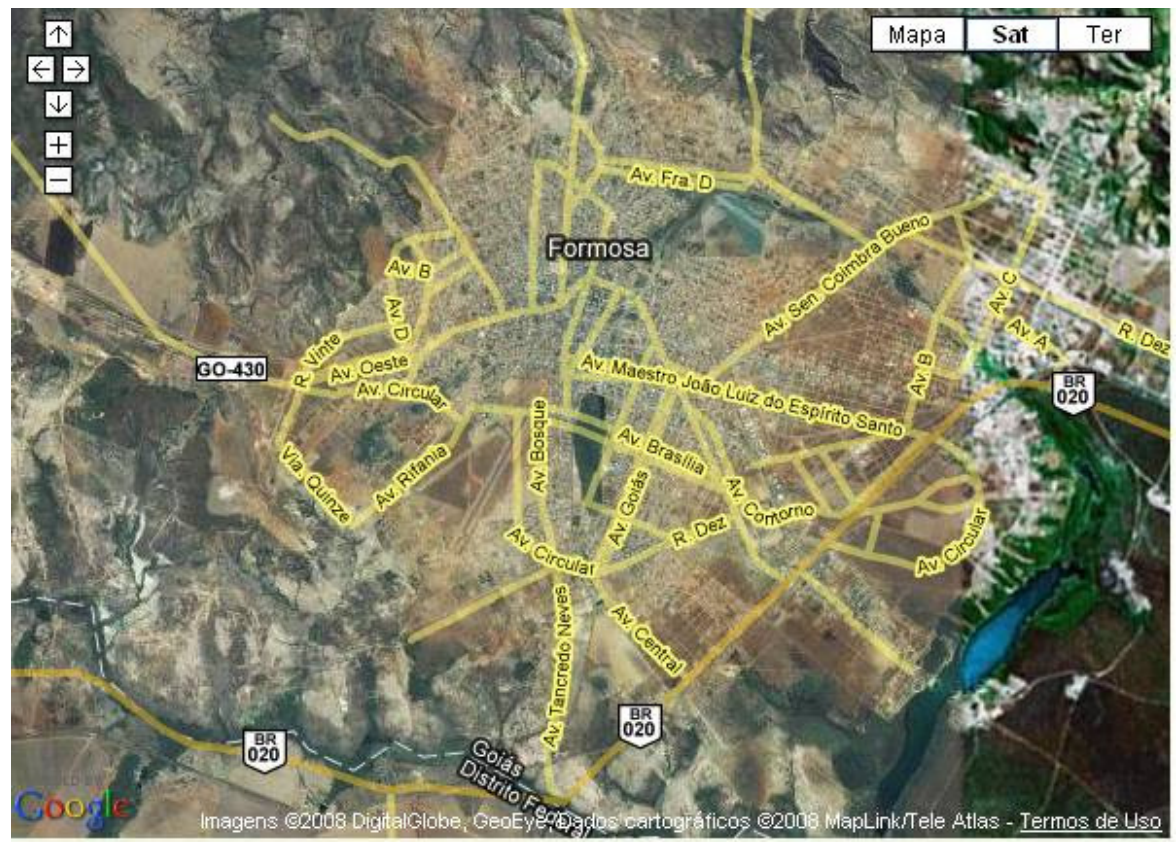

Mapa 2. Imagem de satélite do município de Formosa - GO (GOOGLE, 2009).

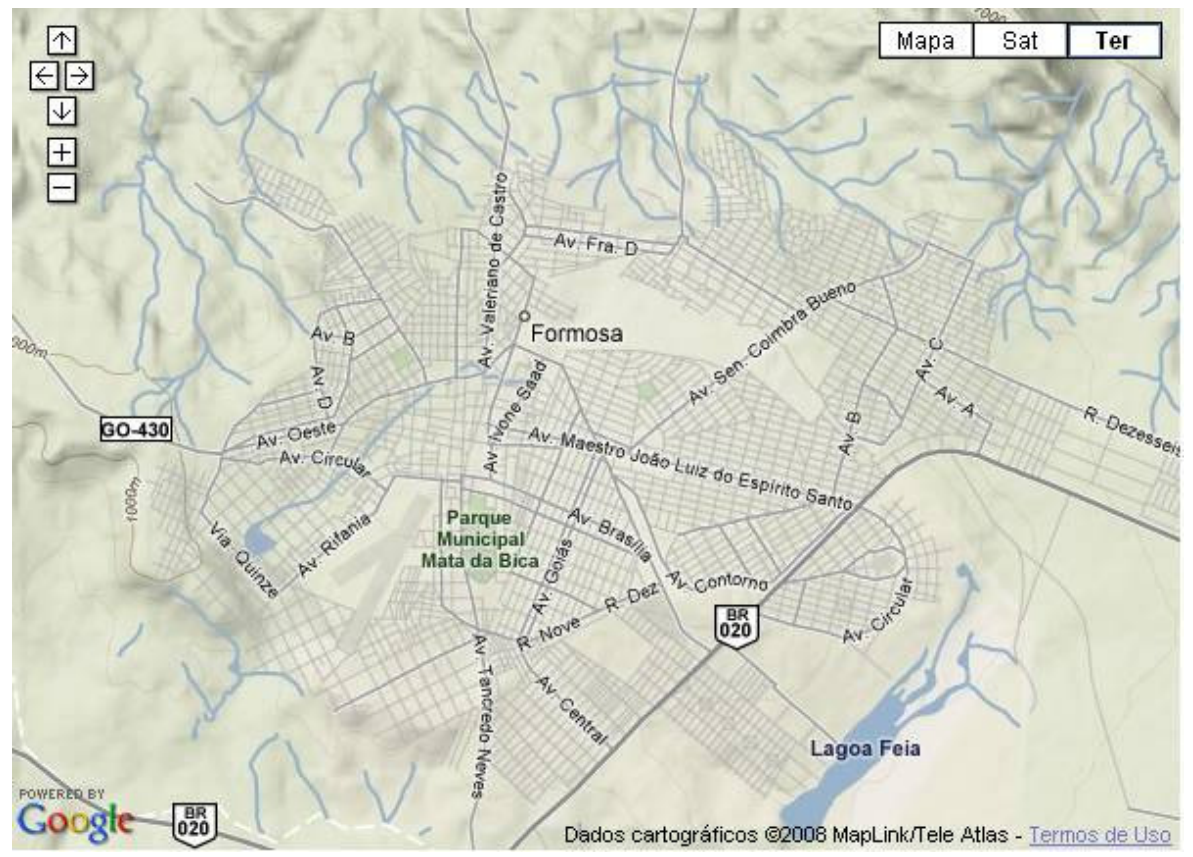

Mapa 3. Mapa do terreno de Formosa - GO (GOOGLE, 2009).

- Indicações de acesso: o acesso utilizado de Brasília á Formosa é feito pela rodovia federal BR 020 por $75 \mathrm{Km}$ e de Formosa à Fazenda Rancho Grande é feito pela rodovia municipal GO 116 por $62 \mathrm{Km}$. O percurso de Brasília à propriedade tem gasto de tempo médio de uma hora e quarenta minutos. De Brasília à Formosa o pavimento da estrada é de asfalto, há boa sinalização na rodovia BR 020, porém de Formosa à fazenda não há nenhum tipo de sinalização ou iluminação e o 
pavimento da estrada é de asfalto por $30 \mathrm{Km}$ e estrada de chão com cascalho por $32 \mathrm{Km}$.

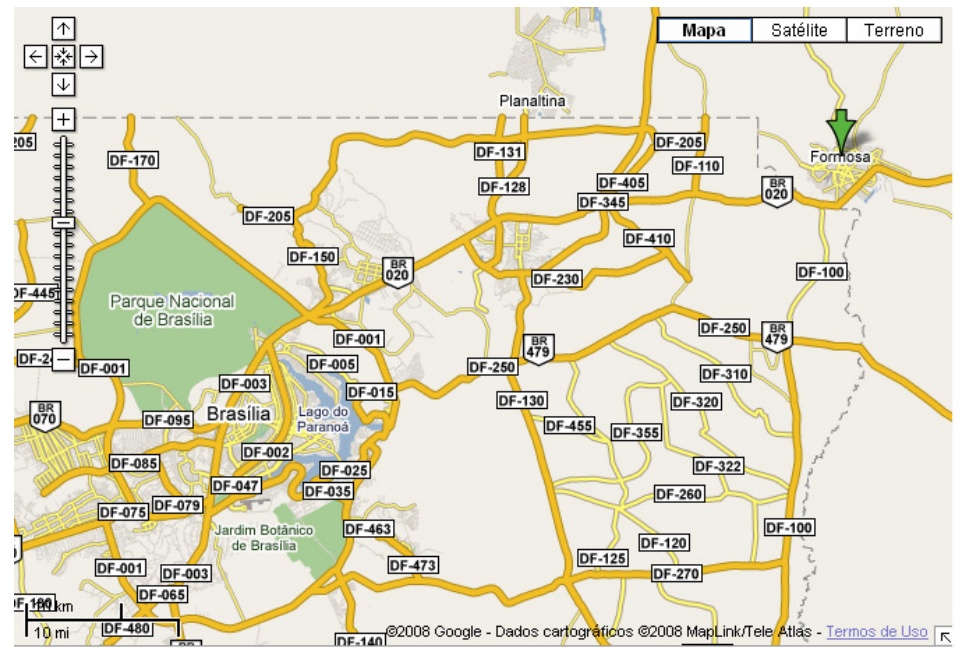

Mapa 4. Mapa rodoviário da região de Formosa - GO e DF (GOOGLE, 2009).

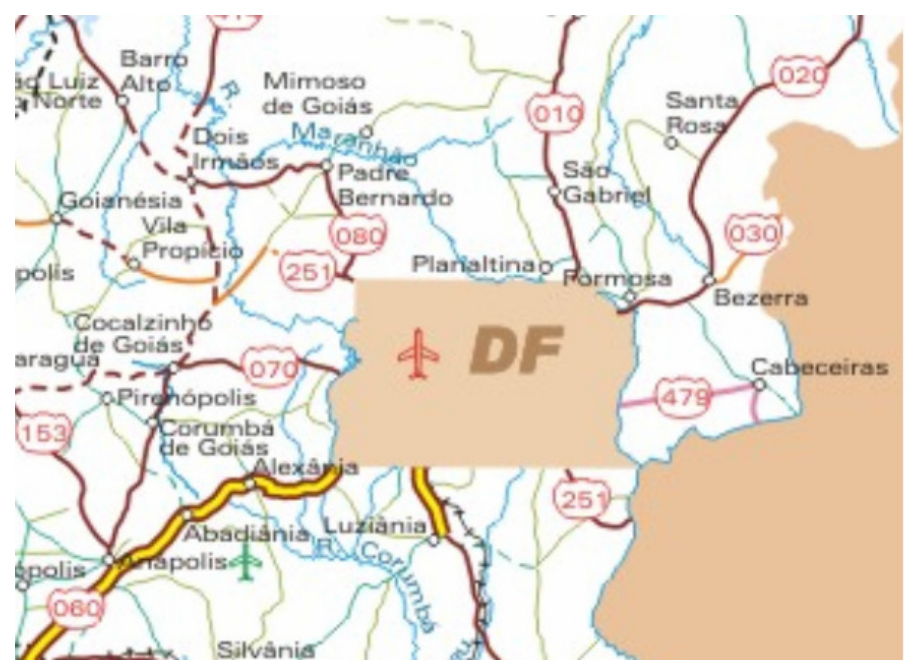

Mapa 5. Mapa rodoviário da região de Formosa - GO e DF (GOOGLE, 2009).

Formosa é um município de Goiás que conta com infra-estrutura médico-hospitalar, odontológica, estabelecimentos financeiros, segurança pública e serviços básicos como banca de jornais e revistas, farmácias, supermercados, etc.

A propriedade em estudo tem como nome completo Fazenda Rancho Grande, seu proprietário é o Dr. Carlos Magno Campos da Rocha, se localiza na GO 116 no km 62 próximo ao município de Formosa e possui área total de 760 hectares. Observar apêndice A que apresenta o memorial descritivo do registro da propriedade. 


\title{
4.2 Microlocalidade
}

Segundo Sirgado:

\begin{abstract}
As acessibilidades influem decisivamente na diferenciação do espaço turístico de uma região, uma vez que a estas estão associadas às condições de bem-estar das populações e a dinâmica das economias locais, numa lógica de relações de atração funcional, espacial e imageticamente diferenciadas entre os múltiplos estabelecimentos humanos e, destes, com os espaços envolventes (SIRGADO, 2006. P. 52).
\end{abstract}

De acordo com a metodologia adotada de Salles, a microlocalidade é a análise da delimitação da área específica, saneamento básico, características naturais, relevo, vegetação, flora e fauna, e hidrografia.

- Delimitação da área específica: a fazenda tem como acesso principal a rodovia BR 020, de Brasília a Formosa com uma distância de 75 km, e o acesso de Formosa a fazenda é de $62 \mathrm{Km}$. O tipo de pavimento da estrada que dá acesso à fazenda é de asfalto e não há sinalização, com distância de $30 \mathrm{Km}$; e de estrada de chã com cascalho sem qualquer tipo de iluminação, com distância de $32 \mathrm{Km}$. Esse trecho possui 12 pontes sem seguridade, controle de capacidade de carga e sem preservação. As condições de acesso variam entre boas e más condições de acordo com a época do ano, de chuvas ou de seca. A paisagem é deslumbrante, com plantações, pastos, árvores e chapada. As formas de acesso interno podem ser melhor realizadas com automóveis de grande porte, como exemplo, picapes, jipes e outros. Na entrada da propriedade há uma placa indicativa, porém com pouca visibilidade e sem iluminação, dentro da propriedade não há sinalização.

As trilhas e caminhos que dão acesso às entradas do rio Água Frio têm como característica principal uma grande quantidade de vegetação nativa que podem ser consideradas APP. Como a propriedade tem fins lucrativos voltados para criação de gado de leite, os próprios animais formaram os caminhos de acesso para o rio, por isso sua extensão é de dois metros de largura, e não contém cerca. Apesar de ser uma área de risco, sua condição de seguridade é precária, pois falta corrimão e escada de acesso para que haja menor impacto ambiental. Essas trilhas e caminhos são variados, mas com possibilidade de implementação a serem estudados.

A sinalização deve ser realizada em toda a propriedade para contribuir com a melhor circulação interna, indicando serviços e facilidades como trilhas, restaurante, estacionamento, áreas de atividade aquática e áreas de descanso, 
que podem vir a se tornar áreas destinadas a visitação pública, já que a propriedade não possui infra-estrutura turística.

As condições de visibilidade são primordiais na estrutura das trilhas e caminhos de curta distância e longa distância, o que se compõe um diferencial na Fazenda Rancho Grande, caracterizando como potencial para implementação.

A manutenção dos equipamentos e instalações é um serviço de contrato com empresas especializadas, o tipo de serviço prestado é referente às necessidades da propriedade, como atividades de gado de leite, cultivo de milho para silagem e gado de corte. Não há manutenção das trilhas e caminhos já que foram abertos pelo gado. É necessário que se faça um planejamento para implementação de trilhas com manutenção periódica para reduzir o impacto ambiental. A manutenção das estradas, jardins, cercas e aceiros é realizada pelo proprietário com fins voltados para melhor desenvolver as atividades da fazenda e da família que visita nos fins-de-semana. A Fazenda Rancho Grande possui uma porteira e um mataburro, para evitar a fuga do gado, como entrada da propriedade que pode ser transformado em um portal centenário, como pode ser observado na figura:

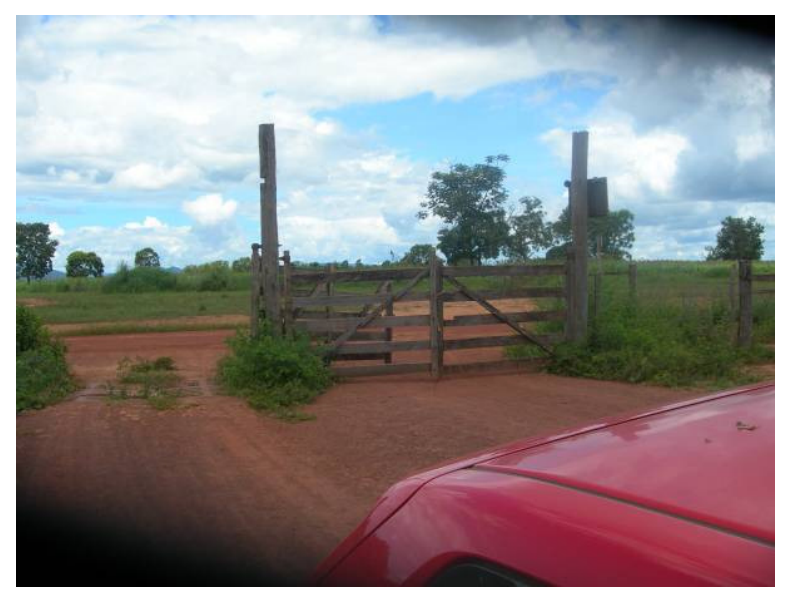

Figura 1. Porteira de entrada e mata-burro.

- Saneamento Básico: o fornecedor de água da fazenda é o Ribeirão do Água Fria, que corta a propriedade. A contenção é feita em caixas d'água que realizam a captação das águas por meio de mangueiras e é distribuída por encanamentos internos. Os reservatórios de água têm capacidade para abastecer a casa principal e as outras duas casas da propriedade, como pode ser observado nas figuras 2 e 3: 


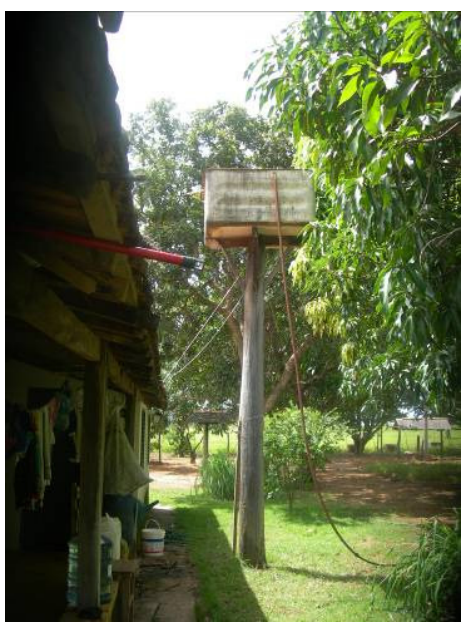

Figura 2. Caixa d'água da casa-sede.

O esgoto sanitário é despejado em fossa séptica ${ }^{1}$ que são uma benfeitoria complementar e necessária às moradias, são importantes no combate a doenças, pois evitam o lançamento dos dejetos humanos diretamente em rios e nascente ou até mesmo na superfície do solo, que é o caso da propriedade em estudo. O seu uso é essencial para a melhoria das condições de higiene das populações rurais. Esse tipo de fossa nada mais é quem um tanque enterrado que recebe os dejetos humanos, retém a parte sólida e inicia o processo biológico de purificação da parte líquida (figura 4).

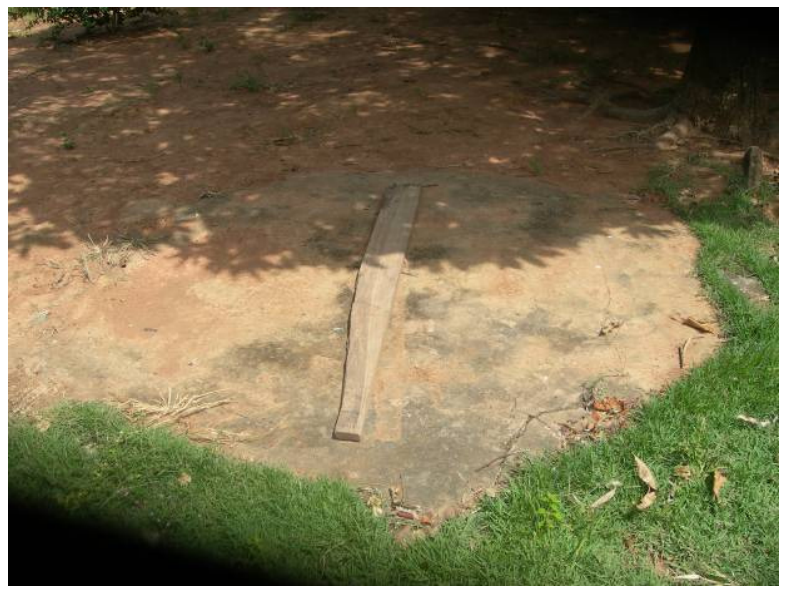

Figura 3. Fossa séptica.

O lixo rural da fazenda é composto de matéria orgânica do dia-a-dia (restos de alimento), matérias recicláveis (vidro, latas, papel e plásticos), pilhas e baterias, lâmpadas e cosméticos, e sua contenção é realizada em fases: acondiciona-se o lixo em sacos plásticos sendo transportado até uma vala onde há a queima desses

\footnotetext{
${ }^{1}$ Fossas sépticas são unidades de tratamento primário de esgoto doméstico nas quais são feitas a separação e transformação da matéria sólida contida no esgoto.
} 
resíduos. A contenção do lixo químico e veterinário é feita pelo recolhimento em tambor, depois é queimado e enterrado em buraco feito na própria propriedade.

A transmissão de energia é feita pela rede pública de Formosa - CELG (Companhia energética de Goiás), com distribuição monofásica que se caracteriza como uma única fase elétrica. A propriedade tem um fator de $200 \mathrm{~V}$ e tem um consumo médio mensal de energia elétrica de $600 \mathrm{MHz}$.

- Características naturais: "o conhecimento das variações climáticas é indispensável para a programação das visitas aos atrativos naturais, porque a paisagem é um espetáculo que tem vida, que muda constantemente" (SALLES, 2006. P. 57).

O clima predominante no município de Formosa, estendendo-se pela região do Vão do Paraná, é tropical chuvoso. Com massas de ar Tropical Atlântica e Equatorial Continental, há uma identificação de duas estações bem definidas com temperaturas elevadas e outras secas com temperaturas mais suaves. Na parte sul é temperado e ameno, no norte e no Vão do Paranã é quente. Formosa tem uma altitude de 918 metros do nível do mar.

Nos meses entre outubro e abril há maior umidade, com índices pluviométricos superiores a $100 \mathrm{~mm} /$ mês. Entre os meses de maio e setembro há um período de seca, onde os totais pluviométricos raramente ultrapassam $50 \mathrm{~mm} / \mathrm{mês}$ e a precipitação média anual esta em torno de $1.600 \mathrm{~mm}$. No trimestre de novembro, dezembro e janeiro ocorrem cerca de $50 \%$ da precipitação anual, período em que as chuvas caem lentamente, favorecendo outros fatores climáticos tais como, infiltração, escoamento superficial e evaporação. A Umidade relativa mantém-se praticamente com máxima de $85 \%$ no período de janeiro a abril, e em agosto atingindo o mínimo de $44 \%$. Nos período mais chuvoso e quente é verificado o maior índice de umidade relativa e, naturalmente, o maior índice de evaporação, no período seco e mais frio há menores índices de umidade relativa do ar e menores índices de evaporação.

- Relevo: o relevo é importante para o turismo por ter paisagens de beleza cênica e para a prática de diversas atividades de lazer. O município de Formosa está localizado no Planalto Central do Brasil e tem uma área de $7.200 \mathrm{Km}^{2}$ com relevo 
formado por extensas chapadas ${ }^{2}$ e terras vermelhas. As principais serras do município são a Serra Geral do Paraná, Boa Vista, Correira Comprida e Corcunda; o principal morro é o morro da Molhadinha. A propriedade se localiza no Vão do Paranã.

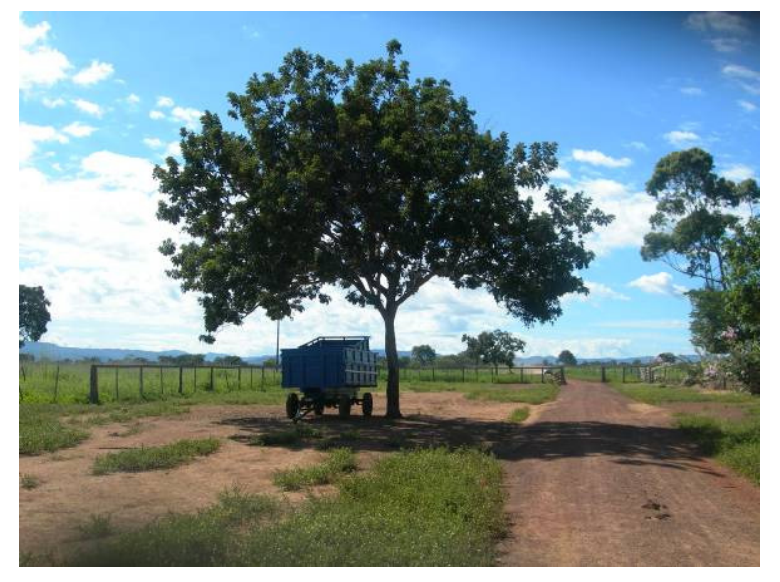

Figura 4. Árvore típica do Cerrado.

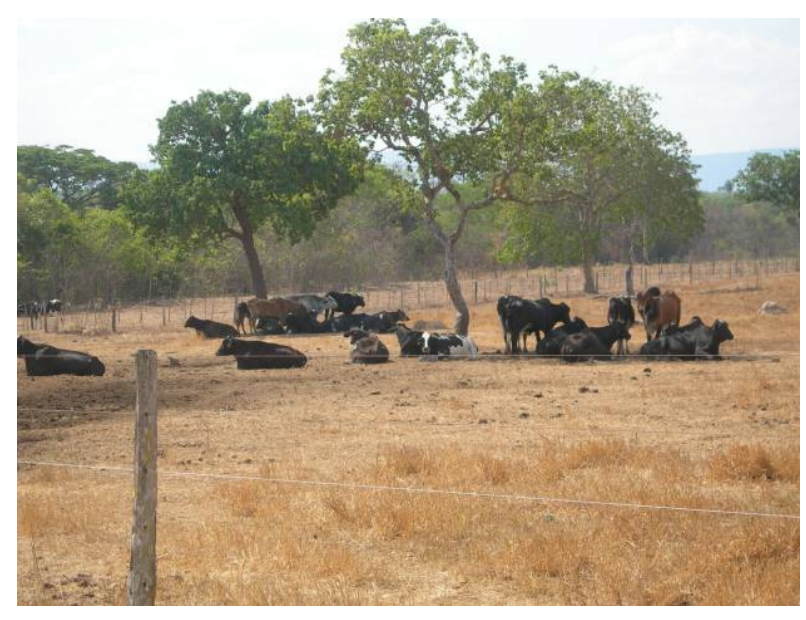

Figura 5. Cerrado.

\footnotetext{
${ }^{2}$ Chapada é uma formação rochosa acima de 600 metros que possui uma porção plana na parte superior. A causa pela qual a superfície da chapada seja plana é a erosão.
} 


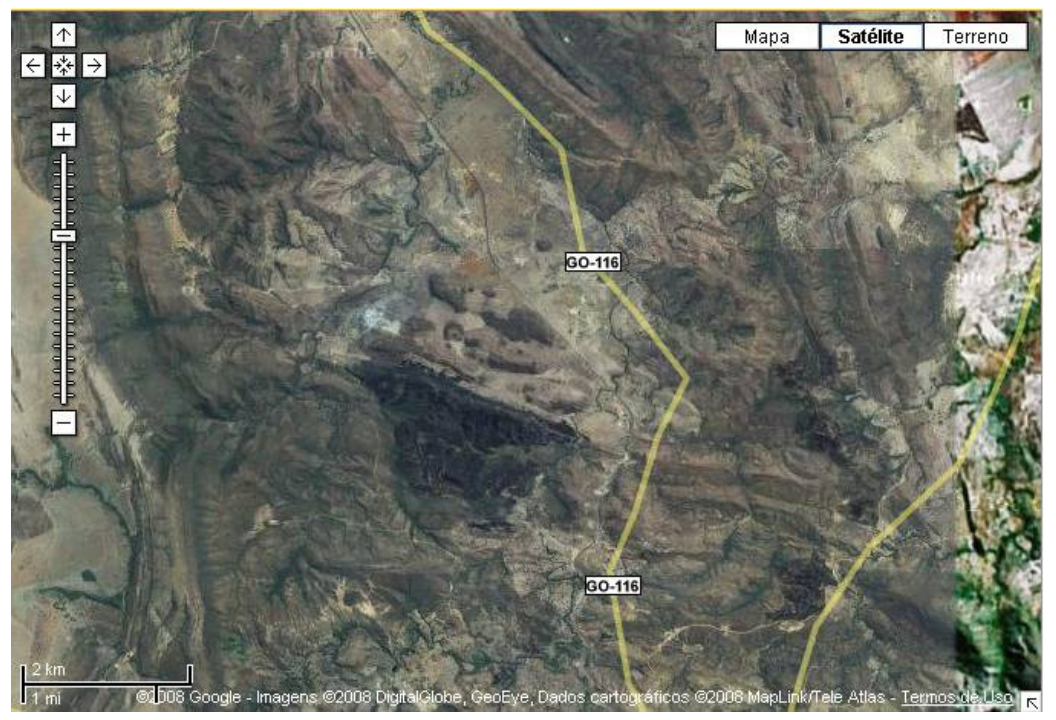

Mapa 6. Vão do Paranã (GOOGLE, 2009).

- Vegetação: o turismo no meio rural acontece principalmente em áreas que tem uma variedade de formações vegetais. Na fazenda é possível observar uma vasta extensão do cerrado e mata ciliar, vegetação típica da região, possuindo vários tipos de madeiras como peroba, jacarandá, angico, jatobá e outras em pequena escala (figuras 5 e 6$)$.

- Flora e fauna: a região é dominada pelo bioma cerrado, onde a endêmica dominante é o cerrado no sentido restrito, destacando a presença do campo cerrado e matas secas de galeria. No cerrado são freqüentes as espécies: pauleite, pau-terra, bacupari, sucupira branca, entre outras. Na comunidade faunística da propriedade, destaca-se a presença de aves indicadoras do ambiente cerrado, como anu-preto, anu-branco, asa-branca, pardal, bem-te-vi, maracanã, pinhé, sabiá e tiziu. Alguns mamíferos, tais como: murídeos, gambá, tatu-peba e algumas espécies de quirópteros.

- Hidrografia: Formosa está situada em privilegiada posição geográfica, pois se encontra no começo das três bacias brasileiras, a do Amazonas representada pelo Ribeirão Bandeirinha, a do Prata representada pelo Ribeirão Pipiripau e a do São Francisco pelo Ribeirão Santa Rita, tendo sido em virtude disto, chamada pelo poeta goiano Leo Lince - "Berço das Águas do Brasil". Os principais rios do município são: o Rio Paranã que é o de maior importância com $500 \mathrm{Km}$ de extensão, surge de uma série de córregos e ribeirões no vale leste da Serra Geral do Paraná, a 4 km da sede do município, corre pelo interior do município na direção norte e recebe mais de 30 afluentes, separa os municípios de Formosa e São João 
D'Aliança, recebe na extremidade norte o Paraim na divisa de Flores de Goiás e Vila Boa para onde segue o seu curso; o Rio Preto nasce na Lagoa Feia, nos limites com o Distrito Federal sendo marco divisório entre ambos, recebe vários afluentes destacando-se o Ribeirão Bezerra, limite natural de Formosa com Cabeceiras; o Rio Urucuia com a nascente situada a $26 \mathrm{Km}$ ao leste, de Formosa com percurso pequeno. As principais lagoas de Formosa são Lagoa Feia, Lagoa da Espora, Lagoa da Vargem, Lagoa dos Veados, Lagoa do Corcunda, Lagoa do Paraim e a Lagoa Grande. As Cachoeiras e as quedas d'água mais apreciadas dos municípios na região do Vão do Paranã - GO são: Cachoeira do Timóteo, Cachoeira da Ursula, Cachoeira do Capetinga, Cachoeira do Paraim, Cachoeira do Itiquira é pó ultimo Cachoeira do Bisnau (Mapa 07).

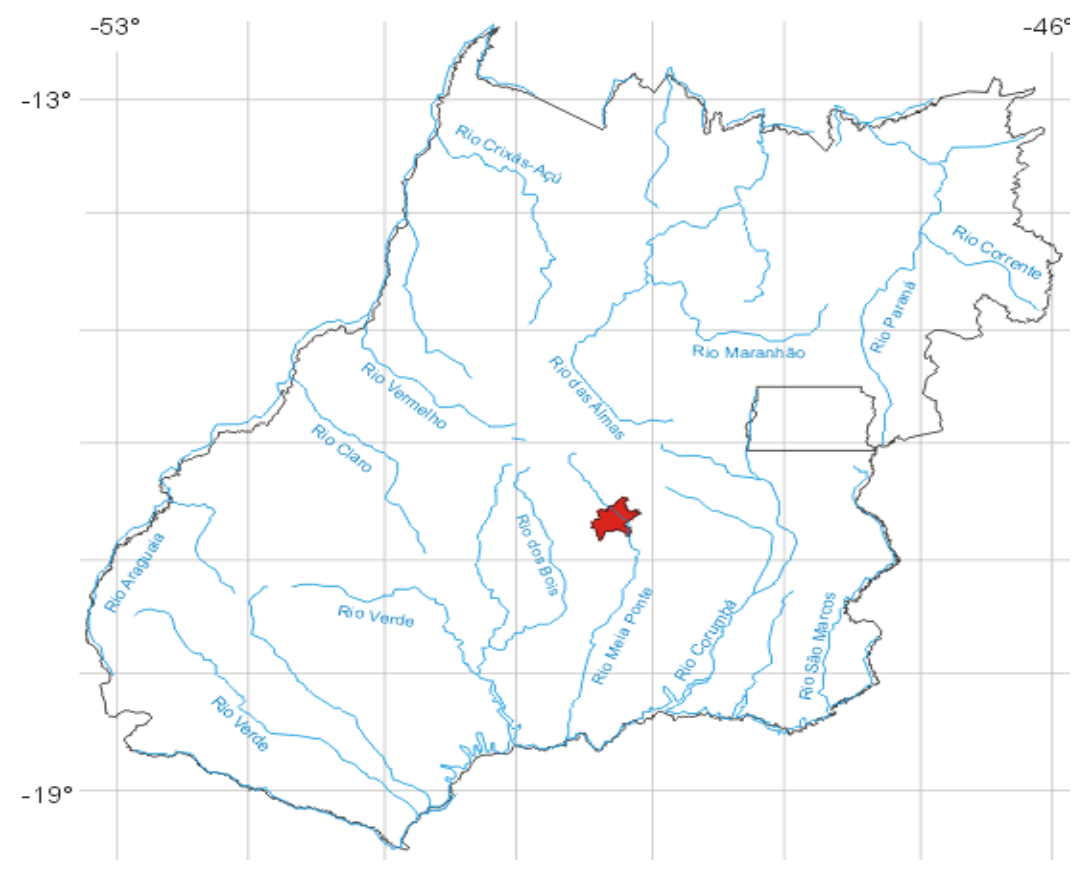

Mapa 7. Mapa hidrográfico de Goiás (WEBCARTA, 2009).

A propriedade é cortada pelo Ribeirão do Água Fria (figura 06) e tem seu limite ao norte indicado pelo Córrego da Capivara. O Ribeirão do Água Fria é o principal recurso turístico a ser avaliado e estudado para implementação de atividades aquáticas na propriedade, como pode ser observado nas figuras (06 e 07): 


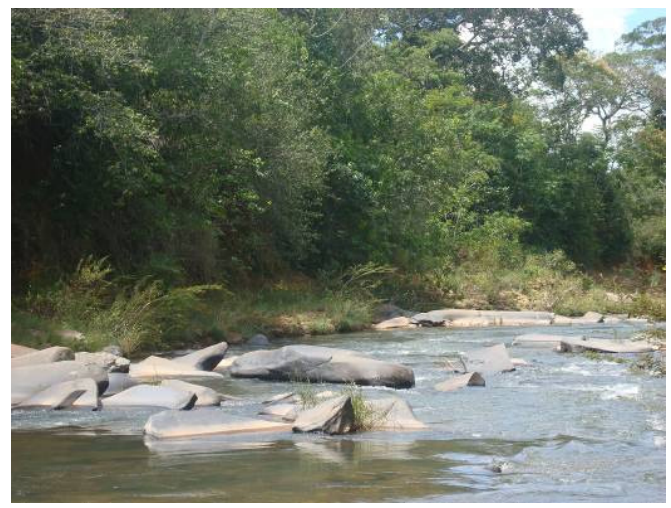

Figura 6. Ribeirão do Água Fria.

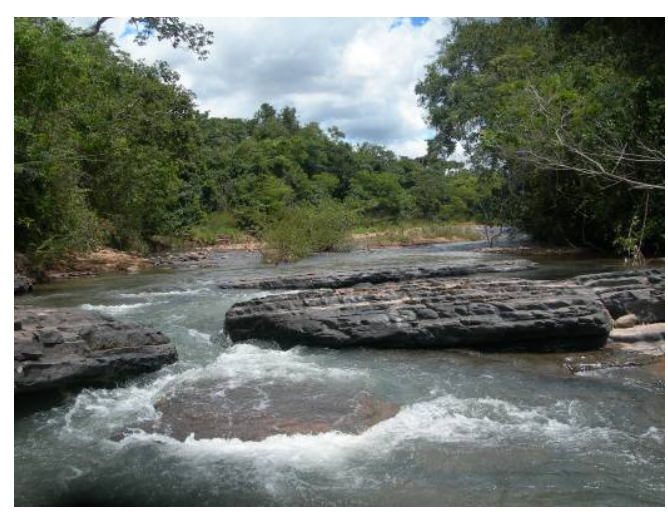

Figura 7. Ribeirão do Água Fria.

\section{3 Área rural}

- Distribuição da área específica: a propriedade possui uma área total de 760 hectares, 32\% da área e de mata nativa que foi protegida por interesse do próprio proprietário, sendo 15 hectares de cultivo de cana-de-açúcar, 05 hectares de milho e 08,2 hectares de sorgo para silagem, alimentação do gado; 450 hectares de pastagem cultivada de capim-andropogon e capim-brachiaria.

- Atividades agro-zootécnicas desenvolvidas, não-comercializadas: a propriedade cultiva diretamente no solo próximos ao curral e à casa-sede, milho, cana e sorgo para serem transformado em silagem para alimentação do gado e capim-andropogon e capim-abrahiaria para pasto. A colheita é feita nos meses de março e abril e outubro e novembro sem uso de agrotóxicos.

- Atividades comercializadas com animais de médio e grande porte: a principal atividade financeira da fazendo é a produção de leite que tem uma produção média diária de $150 \mathrm{~L}$, de $4.500 \mathrm{~L}$ mensal e de $5.4000 \mathrm{~L}$ anual. Feita a ordenha do gado 
de leite, armazena-o em galões de $50 \mathrm{~L}$ que é transportado até o tanque de expansão que se localiza a $10 \mathrm{Km}$ da propriedade, depois é feito o transporte por um caminhão de laticínios que recolhe o leite desse tanque de expansão a cada 02 dias para venda (figuras 08 e 09). O proprietário faz parte de uma associação que se chama APROVA - Associação dos Produtores do Vão do Paranã e é composta por proprietários de fazendas da região do Vão do Paranã.

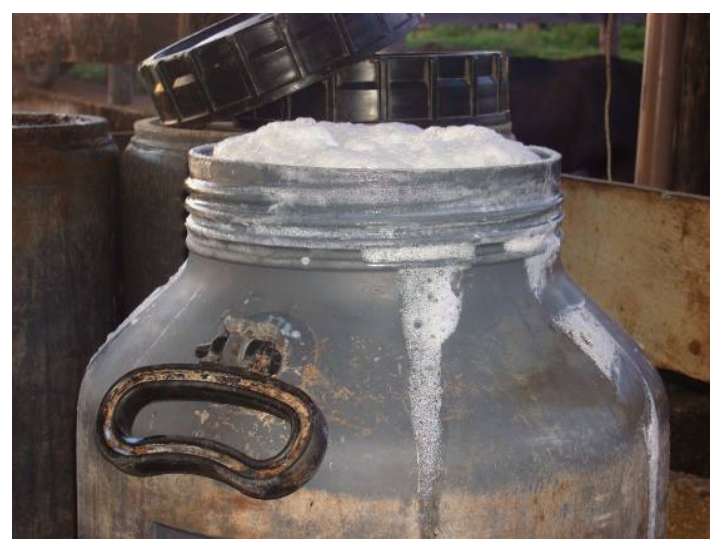

Figura 8. Produção de leite.

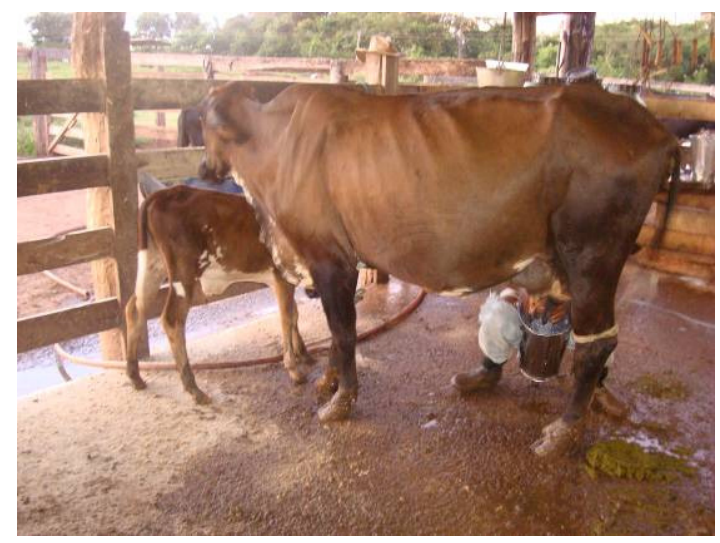

Figura 9. Produção de leite.

O proprietário também trabalha com produção de gado de corte (figura 10) somente na fase inicial, de cria. Sua produção média anual é de 300 animais, sendo 150 machos e 150 fêmeas, desses 50 vacas são vendidas ao ano, desde que tenham peso de $13 @$, ou seja, $390 \mathrm{Kg}$ de peso vivo. Os bezerros são vendidos à produtores de Formosa e as vacas à açougueiros de Formosa. 


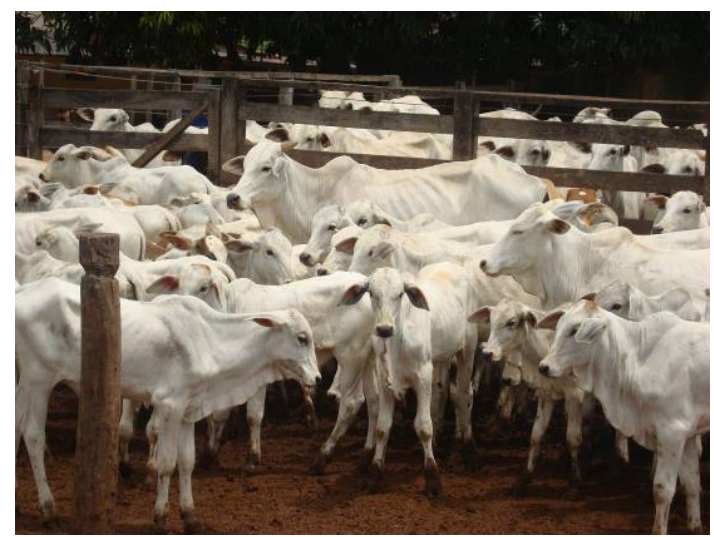

Figura 10. Gado de corte.

O leite e o milho produzidos na propriedade também são utilizados para fabricação de queijo e consumo da família, como pode ser observado nas figuras (11 a 14).

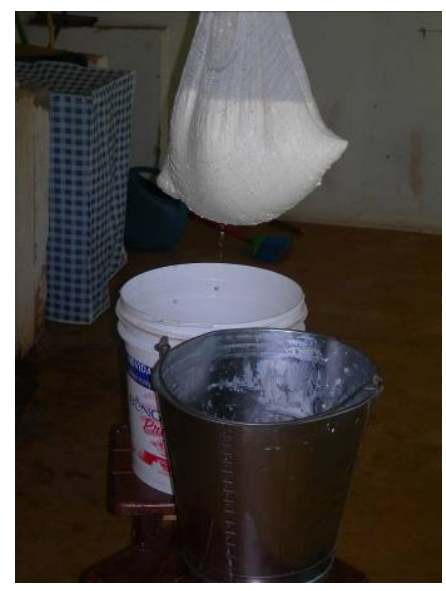

Figura 21. Primeira fase da produção de queijo, separação do leite e do soro.

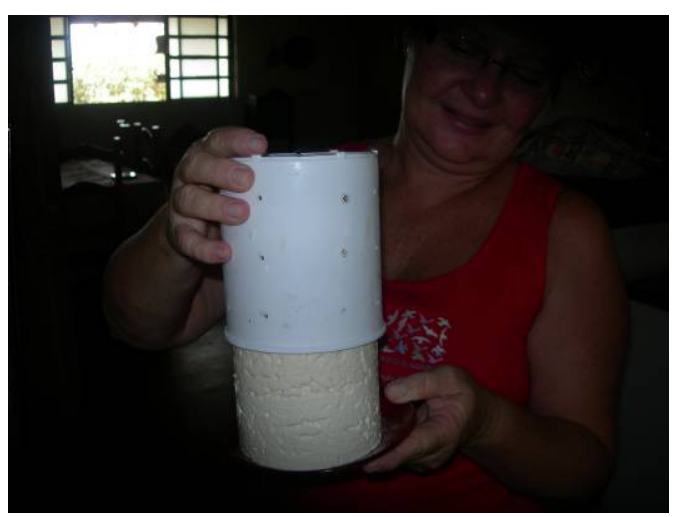

Figura 32. Última fase da produção de queijo, o queijo pronto para consumo. 


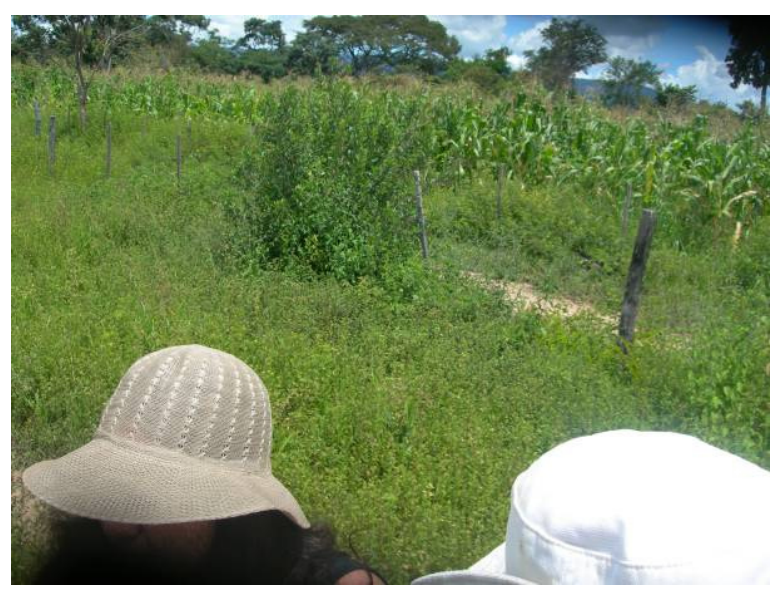

Figura 43. Plantação de milho.

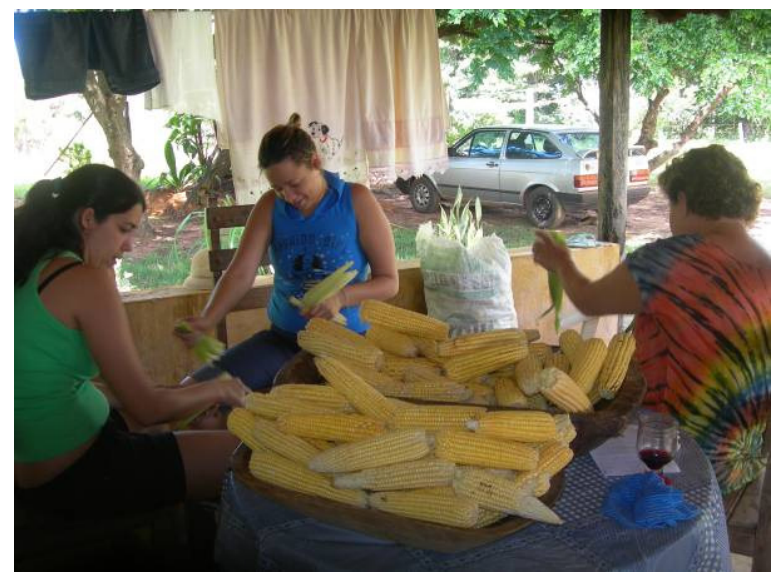

Figura 54. Produção de milho.

\subsection{Atividades turísticas em desenvolvimento}

A propriedade tem potencial para desenvolver atividade no meio rural como atividades de lazer e físicas como nadar no rio, andar a cavalo, caminhar nas trilhas, atividades agropecuárias com suporte de guia como ordenha do gado, fabricação de queijo, vacinação e tatuar o gado para diferenciar os animais, atividades desenvolvidas na agricultura como hortas e pomares. Para essas atividades há disponibilidade de ferramentas e material, sendo que o preço para colhimento de qualquer tipo de produto poderia estar incluso no valor do pacote.

É possível a implementação de trilhas auto-guiadas ou com guias de turismo regional e especializados em atrativos naturais, com intuito educacional para que os visitantes possam conhecer o cerrado. Para isso, será importante um estudo biológico para que haja sinalização dessas espécies, e também um estudo de capacidade de carga, e classificação das trilhas quanto à sua dificuldade. 
Para cavalgada a propriedade possui boas condições para trato físico dos animais, local de pasto, condições dos equipamentos como selas e arreios, e uma bela paisagem circundante, o Vão do Paraná. É possível, também, cavalgadas em torno da propriedade para conhecimento de atividades agropecuárias como montagem de pasto e pastoreio do gado.

É possível atividade para ordenha do gado, com preparo anterior como utilização de botas e chapéis. Existe acesso aos animais mansos, higiene, locais para manuseio e processamento dos produtos.

Também podem ser realizadas atividades de lazer desportivas, atividades aquáticos no Ribeirão do Água Fria que corta a Fazenda Rancho Grande, caminhadas, e fabricação de queijo.

A demanda é real e a propriedade está aberta ao público em geral, vizinhos, hóspedes, convidados especiais, visitas esporádicas e pré-programadas.

As informações citadas nesse inventário podem ser observadas na entrevista realizado com o proprietário Sr. Carlos Magno Campos da Rocha no apêndice C.

\subsection{Memorial descritivo do potencial turístico da Fazenda Rancho Grande}

Na propriedade é possível observar uma área que está adequada à implementação do turismo, como pode ser observa no mapa 08 , que é parte da planta cadastral da propriedade, e corresponde ao local de estudo para implementação do turismo. Verificar mapa completo da planta cadastral no apêndice $B$, e memorial descritivo da propriedade no apêndice $A$. 


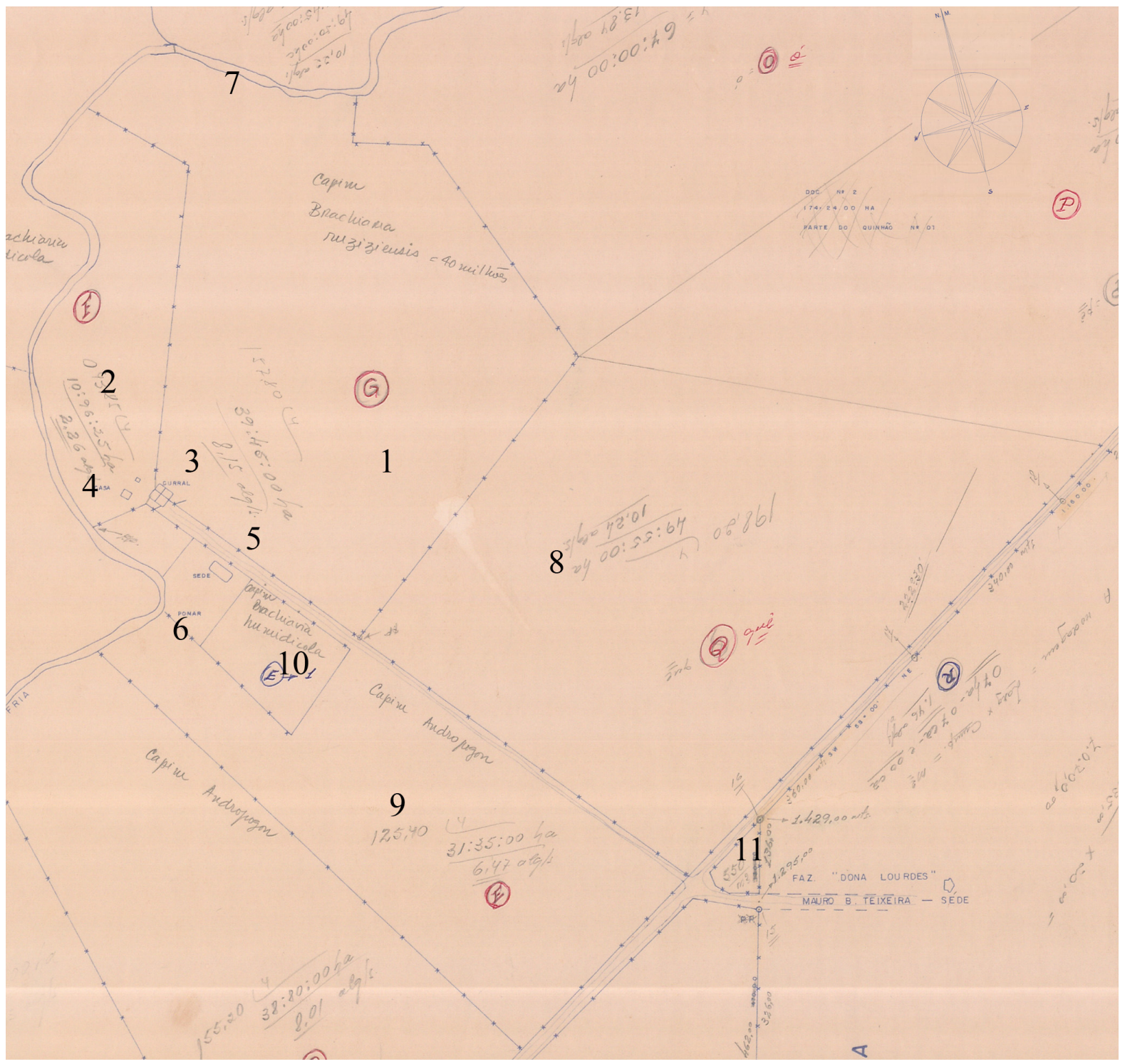

Mapa 8. Parte da planta cadastra da propriedade Fazenda Rancho Grande.

Os pontos 1 e 8 referem-se aos pastos próximo à casa-sede com plantio de capimbrachiaria. O ponto 2 refere-se ao pasto próximo à casa do caseiro. 0 ponto 3 indica o curral que possui equipamentos para vacinação, tatuagem do gado, mocho e outras atividades relacionadas ao gado, como à ordenha.

O ponto 4 apresenta a casa do caseiro que também da acesso ao Ribeirão do Água Fria. Essa casa possui três quartos, fogão a lenha, local para armazenagem da silagem, o chiqueiro e o galinheiro.

O ponto 5 apresenta a casa sede que possui quatro quartos equipados com camas e armários, sala de estar com mesa para refeições com seis lugares, televisão, 
estante e dois sofás, vem sendo utilizado pelos familiares do proprietário e amigos que visitam a propriedade, sendo toda rodeada por varanda. Na casa existe um banheiro e uma cozinha com fogão, pia, armários, filtro de barro, equipamento necessário para fabricação de queijo, geladeira e freezer.

O ponto 6 define a localização do pomar e horta existentes na propriedade com cultivo de melancia, baru, jabuticaba, pitanga, acerola, graviola, pequi, tamarindo, manga, laranja e limão, chuchu, abóbora e hortaliças. Nesse ponto também encontra-se uma churrasqueira utilizada pelo proprietário quando há visitas na propriedade.

No ponto 7 é possível observar o local de acesso ao Ribeirão do Água Fria destinado ao estudo para implementação de infra-estrutura turística para acesso dos visitantes as trilhas auto-guiadas, placas ilustrativas, manutenção de atividades aquáticas . $\mathrm{O}$ acesso a esse ponto é feito pelo curral (ponto 3) e atravessa o pasto (ponto 1) com $100 \mathrm{~m}$ de distância, deve-se atravessar também uma trilha com 100 $\mathrm{m}$ de distância aberta pelo gado que vai ali para beber água.

O ponto 8 apresenta pasto com plantio de capim-andropogon, no ponto 9 refere-se à plantação de milho utilizado na fabricação de silagem e sorgo para alimentação do gado. O proprietário também utiliza o milho para alimentação.

O ponto 10 refere-se ao pasto vizinho à casa-sede onde podem ser realizadas atividades de cavalgada e há plantio de capim-brachiaria.

O ponto 11 sinaliza a entrada da propriedade onde existem uma porteira e um mata-burro para impedir a fuga do gado. A distância da entrada à casa-sede é de $300 \mathrm{~m}$. 


\section{PLANO FINANCEIRO DA FAZENDA HOTEL RANCHO GRANDE}

A seguir são apresentados alguns itens componentes do plano de negócios para melhor entendimento do plano financeiro.

\subsection{SUMÁRIO EXECUTIVO}

Este plano financeiro define como será a criação e o funcionamento da Fazenda Hotel Rancho Grande, empresa voltada à exploração do turismo rural, que traz na sua essência o contato com a natureza distanciando o hóspede da vida agitada dos grandes centros urbanos.

\subsubsection{Objetivo do plano}

O objetivo desse plano financeiro é organizar idéias e traçar objetivos de forma consistente para a implementação e desenvolvimento da Fazenda Hotel Rancho Grande.

\subsubsection{Descrição do Negócio}

A Fazenda Hotel Rancho Grande atuará no setor hoteleiro voltado ao turismo rural com criatividade e inovação, tendo sua sede localizada no município de Formosa, próximo ao Ribeirão do Água Fria. O negócio terá como sócios Larissa Uchôa da Rocha (ostensiva), turismóloga, especialista em gestão de negócios em turismo, e Carlos Magno Campos da Rocha (majoritário), engenheiro agrônomo.

\subsubsection{Visão}

Filion apud Dolabela define visão como "uma imagem, projetada no futuro, do lugar que se quer ver ocupado pelos seus produtos no mercado, assim como a imagem projetada do tipo de organização necessária para consegui-lo" (DOLABELA, 2006. P. 76). 
Sendo assim, a empresa tem a seguinte visão: ser conhecida em 5 anos na região como um centro de excelência em qualidade de vida para promover momentos inesquecíveis e superar expectativas.

\subsubsection{Missão}

Na obra de Salim, encontra-se a seguinte definição para missão: "é a função que ela vai exercer junto ao mercado, provendo-lhe de produtos e/ou serviços" (SALIM, HOCHMAN, RAMAL, RAMAL, 2005. P. 44).

Ao apresentar esse conceito, define-se a missão da empresa como: hospedar os que amam a natureza, servindo-os com qualidade e conforto, contribuindo para a preservação do meio ambiente.

\subsubsection{Objetivos e metas}

a) Objetivos: conquistar a liderança no mercado regional; obter excelência no serviço de hospedagem e turismo rural; vender com qualidade e criatividade.

b) Metas: em 3 anos, obter grandes parcerias com 10 instituições, tanto de ensino quanto empresariais, para exclusividade em reuniões e aprendizados na prática; disponibilizar cursos de atendimento e de guia para os funcionários da empresa aprimorarem; em 5 anos aumentar as hospedagens em 75\% (setenta e cinco por cento).

\subsubsection{Fatores críticos de sucesso}

Os fatores críticos de sucesso da fazenda hotel são: estabelecimento de parcerias; credibilidade e compromisso profissional; eficiência e qualidade nos serviços; e, investimento em inovação.

\subsubsection{Princípios e valores}

A Fazenda Hotel Rancho Grande tem os seguintes princípios e valores: 
a) Dedicação aos clientes: a empresa tem o compromisso de cuidar de cada cliente, construindo relações amistosas com profissionalismo para melhor servi-los de acordo com suas expectativas;

b) Foco nos resultados: comprometimento em integrar o cliente à natureza da melhor forma possível, de acordo com suas necessidades e exigências para que suas expectativas sejam superadas;

c) Ambiente organizacional: incentivar a sustentabilidade e a integração com a natureza de forma criativa e maximizando resultados, pois a empresa acredita em seus colaboradores como sendo grandes aliados para o sucesso, com ótimo relacionamento com o quadro de funcionários, independente da hierarquia, o que colabora para a satisfação do cliente e a perpetuação da empresa.

\subsection{RESUMO DA EMPRESA}

Este item é muito importante para a empresa, pois é nele que se identifica a oportunidade e a transforma em um negócio.

\subsubsection{A Empresa}

A Fazenda Hotel Rancho Grande é uma empresa que se destina a integrar o cliente ao meio natural através de sua hospedagem em meio rural e participação em atividades rurais como ordenha do gado, pastoreio do gado e cavalgada.

A empresa tem o objetivo de proporcionar aos seus clientes a integração com a natureza para relaxamento e de forma a superar expectativas, propiciando grandes acontecimentos.

A Fazenda Hotel Rancho Grande atuará no mercado com o foco no turismo rural oferecendo pacotes e criando parcerias com instituições de ensino e empresariais, como universidades, faculdades, colégios de ensino médio, empresas de agricultura e turísticas para realização de reuniões e procedimentos práticos.

\subsubsection{Sumário Startup}


É importante observar a idade em que se encontra a empresa para que se possa criar a visão do plano, por exemplo, se a empresa for uma startup ${ }^{3}$, tudo deve ser construído pela primeira vez, enquanto que em empresas que já existem no mercado há algum tempo, já existem dados para que um novo plano venha a ser construído. O plano de negócio é essencial para a startup, pois é nele que se detalhará as condições futuras da empresa.

Tabela 1. Sumário Startup

\begin{tabular}{|l|l|l|}
\hline Etapas & Ações & $\begin{array}{l}\text { Projeção } \\
\text { tempo }\end{array}$ \\
\hline 1 & Revisão do plano de negócios & 25 dias \\
\hline 2 & $\begin{array}{l}\text { Início e finalização das obras dos chalés; Início e } \\
\text { finalização do processo de abertura da firma; } \\
\text { Desenvolvimento do site e material de divulgação. }\end{array}$ & 85 dias \\
\hline 3 & $\begin{array}{l}\text { Compra e instalação de equipamentos (computador, } \\
\text { mesa, cadeiras...) e material inicial; Contratação de } \\
\text { funcionários; Início da divulgação e busca por } \\
\text { parcerias. }\end{array}$ & \\
\hline 4 & Início das operações & 12 dias \\
\hline & TOTAL & $\mathbf{1 6 7 \text { dias }}$ \\
\hline
\end{tabular}

\subsubsection{Localização da empresa}

A empresa Fazenda Hotel Rancho Grande foi estudada e planejada para sua instalação na Fazenda Rancho Grande, na rodovia GO 116, km 62, em Formosa, Goiás, por ser uma cidade em desenvolvimento turístico e ter um número expressivo de atrativos naturais ao redor da cidade.

A fazenda tem como acesso principal a rodovia BR 020, de Brasília a Formosa com uma distância de $75 \mathrm{~km}$, e o acesso de Formosa a fazenda é de $62 \mathrm{~km}$. O tipo de pavimento da estrada que dá acesso à fazenda é de asfalto, com distância de 30 $\mathrm{km}$; e o restante é de estrada de chão com cascalho com distância de $32 \mathrm{~km}$.

A escolha dessa propriedade foi devida à facilidade e isenção de aluguel por ser propriedade dos sócios, minimizando assim os custos fixos.

\footnotetext{
${ }^{3}$ Startup: é aquela que está sendo formada a partir da visão de um grupo de empreendedores, que se juntaram para concretizá-la. (SALIM, HOCHAN, RAMAL, RAMAL, 2005. P. 13).
} 


\subsection{PRODUTOS E SERVIÇOS}

A empresa Fazenda Hotel Rancho Grande, é uma empresa de hospedagem em meio rural que vende serviços na natureza, por isso a necessidade de acompanhamento de um guia especializado para promover a segurança de seus clientes.

Acomodações: o empreendimento contará com 10 (dez) chalés padronizados no estilo rústico com varanda e uma garagem cada, porém com conforto e bem-estar.

Restaurante: comidas típicas goianas com acompanhamento de uma economista doméstica.

Trilha: trilha suspensa de 100 metros que chega ao Ribeirão do Água Fria para que sejam realizadas atividades aquáticas; trilha para cavalgada na beira do Ribeirão; cicloturismo; e, trilha para caminhada na beira do Ribeirão.

Esportes Aquáticos: no Ribeirão do Água Fria é possível realizar atividades como bóia-cross, tirolesa, canoagem.

Cavalgada: passeio a cavalo pela propriedade para observação da fauna e flora.

Atividades Rurais: ordenha do gado, produção de queijo, vacinação do gado, cavalgada ao redor da propriedade.

Preço: será cobrado o valor de $R \$ 150,00$ (cento e cinquenta reais) por diária em apartamento duplo com café da manhã e almoço inclusos, demais serviços de alimentação serão cobrados à parte. É necessário o acompanhamento de guia de turismo para os serviços oferecidos, o que acarretará na cobrança de $R \$ 50,00$ (cinquenta reais) por guia.

\subsection{ALGUMAS AÇÕES LIGADAS À ÁREA DE MARKETING}

Oportunamente, o empreendimento pretende desenvolver um plano de marketing para dar continuidade ao plano de negócios que aqui começa a ser elaborado com o plano financeiro.

\subsubsection{Análise de mercado}


A análise de mercado desse plano financeiro foi desenvolvida considerando os tópicos a seguir:

a) Segmentação de mercado: a empresa atuará no segmento de mercado de turismo rural, determinando seu mercado-alvo os moradores das cidades de Brasília/DF e Formosa/GO, e seu entorno. Pessoas que pretendem buscar um ar bucólico e esquecer a vida agitada da cidade.

b) Análise da concorrência: a cidade de Formosa apresenta 3 consideráveis concorrentes da Fazenda Hotel Rancho Grande, são eles:

Tabela 2. Análise dos concorrentes.

\begin{tabular}{|l|l|c|c|c|c|c|}
\hline & Qualidade & $\begin{array}{c}\text { Valor da } \\
\text { diária para } \\
\text { duplo }\end{array}$ & $\begin{array}{c}\text { Condições } \\
\text { de } \\
\text { pagamento }\end{array}$ & Localização & Atendimento & Serviços ao cliente \\
\hline Concorrente 3 & Luxo & $\mathrm{R} \$ 300,00$ & $\mathrm{~A}$ vista & $\begin{array}{c}\text { Rodovia GO } 524 \\
\mathrm{~km} 04- \\
\text { Formosa/GO }\end{array}$ & A desejar & $\begin{array}{c}\text { Acomodações, } \\
\text { Restaurante, Trilha, } \\
\text { Esportes Aquáticos, } \\
\text { Cavalgada. }\end{array}$ \\
\hline Concorrente 2 & Moderado & $\mathrm{R} \$ 130,00$ & $\begin{array}{c}\text { A vista e pode } \\
\text { ser negociado }\end{array}$ & $\begin{array}{c}\text { Vale do Paranã } \\
\text { - Formosa/GO }\end{array}$ & Satisfatório & $\begin{array}{c}\text { Acomodações, } \\
\text { Restaurante, Trilha, } \\
\text { Pesca, Esportes } \\
\text { Aquáticos e Aves }\end{array}$ \\
\hline Concorrente 1 & Superior & $\mathrm{R} \$ 165,00$ & $\begin{array}{c}\text { Duas parcelas } \\
\text { (entrada + 30 } \\
\text { dias) }\end{array}$ & $\begin{array}{c}\text { Distrito Bezerra } \\
\text { - Formosa/GO }\end{array}$ & A desejar & $\begin{array}{c}\text { Acostaurante, Trilha, } \\
\text { Esportes Aquáticos, } \\
\text { Atividades Rurais. }\end{array}$ \\
\hline
\end{tabular}

Tabela 3. Análise do Concorrente 1.

\begin{tabular}{|l|l|}
\hline Pontos Fortes & Pontos Fracos \\
\hline Variedade de apartamentos; & Não há flexibilidade nas negociações; \\
\hline $\begin{array}{l}\text { Grande quantidade de equipamentos de } \\
\text { lazer; }\end{array}$ & Pacotes fechados sem flexibilidade; \\
\hline Pensão completa inclusa na diária. & Demora no atendimento. \\
\hline
\end{tabular}

Tabela 4. Análise do Concorrente 2.

\section{Pontos Fortes}

Flexibilidade nas negociações;

Grande variedade de equipamentos de lazer.

\section{Pontos Fracos}

Falta de presteza no atendimento;

Pouca divulgação. 
Tabela 5. Análise do Concorrente 3.

\begin{tabular}{|l|l|}
\hline Pontos Fortes & Pontos Fracos \\
\hline Tradicional na região; & O atrativo está abandonado; \\
\hline Grande quantidade de atrativos naturais; & Falta de presteza no atendimento; \\
\hline Pensão completa inclusa na diária. & Pouco uso de meios de comunicação. \\
\hline
\end{tabular}

\subsubsection{Análise SWOT do empreendimento}

Tabela 6. Análise SWOT.

\section{OPORTUNIDADES}

* público segmentado para turismo rural;

* busca do público para lazer;

* instituições empresariais provendo

reuniões para integrar a equipe fora do ambiente de trabalho;

* trabalhos práticos de universidades e faculdades.

\section{PONTOS FORTES}

* competência dos sócios;

* inovações para segurança constantes;

* serviços diferenciados concorrentes;

* qualidade dos serviços.

\section{AMEACAS}

* sazonalidade;

* limitação de público para este tipo de segmento;

* incapacidade de improvisações devido ao tipo de negócio.

\section{PONTOS FRACOS}

${ }^{*}$ Custos operacionais;

* Inexperiência dos sócios;

* Acessibilidade;

* Sinalização.

\subsection{ALGUMAS AÇÕES LIGADAS À ÁREA OPERACIONAL}

Oportunamente, o empreendimento pretende desenvolver um plano operacional para dar continuidade ao plano de negócios que aqui começa a ser elaborado com o plano financeiro.

a) Estrutura física:

Os itens relacionados abaixo, completam a estrutura física básica para implementação da fazenda hotel na propriedade: 
Tabela 7. Estrutura física básica.

\begin{tabular}{|l|l|}
\hline Mobília & Quantidade \\
\hline Computador & 1 \\
Impressora multifuncional & 1 \\
Impressora fiscal & 1 \\
Aparelho de Televisão & 7 \\
Ventilador & 7 \\
Frigobar & 6 \\
Equipamentos de cozinha & 7 \\
Central Telefônica & 1 \\
Máquinas & 3 \\
Mesa & 1 \\
Sofás e Cadeiras & 1 \\
Armário & 6 \\
\hline Objeto & \\
\hline Roupa de cama & 12 \\
Roupa de banho & Quantidade \\
Conjunto de panelas e talheres & 12 \\
\hline
\end{tabular}

b) Estrutura organizacional:

A gerência da empresa será composta pelos dois sócios, um sócio será responsável pela gerência funcional envolvendo as atividades realizadas na propriedade e hospedagem, e o outro sócio será responsável pela gerência administrativa (funcionários e serviços relacionados), além da gerência comercial e financeira.

A empresa só terá o interesse de contratar estagiários em seu quadro fixo a partir do segundo ano, pois, além de fornecer oportunidades de aprendizado ao estudante, a organização minimiza seus custos.

A empresa terá três funcionários, um exercerá a função de guia de turismo, outro de camareira e outro auxiliando na produção de alimentos juntamente com a nutricionista encarregada.

Por meio de um estudo de planejamento turístico realizado em 2008 na propriedade foi possível verificar a viabilidade técnica e ecológica que visa indicar as medidas básicas a serem tomadas para implementação do hotel nessa propriedade, em anexo.

\subsection{PLANO FINANCEIRO}


a) Investimento inicial:

Nesta etapa do plano financeiro, serão levantados os gastos iniciais básicos para a abertura da empresa, como é apresentado a seguir:

Tabela 8. Investimento fixo.

\begin{tabular}{|c|c|c|c|}
\hline Serviços contábeis & Quantidade & Valor unitário & Valor total \\
\hline Registro da empresa & 01 & $\mathrm{R} \$ 186,00$ & $\mathrm{R} \$ 186,00$ \\
\hline Alvará de localização & 01 & $\mathrm{R} \$ 50,00$ & $\mathrm{R} \$ 50,00$ \\
\hline \multirow[t]{2}{*}{ Alvará de funcionamento } & 01 & $\mathrm{R} \$ 98,00$ & $\mathrm{R} \$ 98,00$ \\
\hline & & TOTAL & $R \$ 334,00$ \\
\hline Mobília & Quantidade & Valor unitário & Valor total \\
\hline Computador & 01 & $\mathrm{R} \$ 1.355,00$ & $\mathrm{R} \$ 1.355,00$ \\
\hline Aparelho multifuncional HP & 01 & $\mathrm{R} \$ 450,00$ & $\mathrm{R} \$ 450,00$ \\
\hline Impressora fiscal & 01 & $R \$ 630,00$ & $\mathrm{R} \$ 630,00$ \\
\hline Aparelho de telefone & 01 & $\mathrm{R} \$ 70,00$ & $\mathrm{R} \$ 70,00$ \\
\hline Ventilador & 07 & $\mathrm{R} \$ 156,00$ & $\mathrm{R} \$ 1.092,00$ \\
\hline Mesa & 01 & $\mathrm{R} \$ 953,00$ & $\mathrm{R} \$ 953,00$ \\
\hline Cadeira & 06 & $\mathrm{R} \$ 40,00$ & $R \$ 240,00$ \\
\hline Bebedouro & 05 & $R \$ 290,00$ & $\mathrm{R} \$ 1.450,00$ \\
\hline Armários & 06 & $\mathrm{R} \$ 281,00$ & $\mathrm{R} \$ 1.686,00$ \\
\hline Aparelhos de televisão & 07 & $\mathrm{R} \$ 389,00$ & $\mathrm{R} \$ 2.723,00$ \\
\hline Frigobar & 06 & $\mathrm{R} \$ 584,00$ & $\mathrm{R} \$ 3.504,00$ \\
\hline Máquina de lavar roupa & 01 & $\mathrm{R} \$ 549,00$ & $\mathrm{R} \$ 549,00$ \\
\hline Fogão & 01 & $\mathrm{R} \$ 975,00$ & $\mathrm{R} \$ 975,00$ \\
\hline Freezer e geladeira & 01 & $\mathrm{R} \$ 2.135,00$ & $\mathrm{R} \$ 2.135,00$ \\
\hline Sofá & 02 & $\mathrm{R} \$ 542,00$ & $\mathrm{R} \$ 1.084,00$ \\
\hline Roupa de cama e banho & 12 & $\mathrm{R} \$ 112,00$ & $\mathrm{R} \$ 1.344,00$ \\
\hline Conjunto de panela e talher & 01 & $\mathrm{R} \$ 225,00$ & $\mathrm{R} \$ 225,00$ \\
\hline \multirow[t]{2}{*}{ Veículo } & 01 & $\mathrm{R} \$ 16.000,00$ & $\mathrm{R} \$ 16.000,00$ \\
\hline & & TOTAL & $\mathrm{R} \$ 36.465,00$ \\
\hline Instalação Internet & Quantidade & Valor unitário & Valor total \\
\hline Modem ADSL & 01 & $\mathrm{R} \$ 186,00$ & $\mathrm{R} \$ 186,00$ \\
\hline \multirow[t]{2}{*}{ Mão de obra } & 01 & $\mathrm{R} \$ 100,00$ & $\mathrm{R} \$ 100,00$ \\
\hline & & TOTAL & $\mathrm{R} \$ \mathbf{2 8 6 , 0 0}$ \\
\hline Obras & Quantidade & Valor unitário & Valor total \\
\hline \multirow[t]{2}{*}{ Reforma } & 424 & $\mathrm{R} \$ 232,00 \mathrm{~m}^{2}$ & $\mathrm{R} \$ 98.368,00$ \\
\hline & & TOTAL & $\mathrm{R} \$ \mathbf{9 8 . 3 6 8 , 0 0}$ \\
\hline Marketing & Quantidade & Valor unitário & Valor total \\
\hline Material de divulgação & 01 & $\mathrm{R} \$ 600,00$ & $\mathrm{R} \$ 600,00$ \\
\hline \multirow[t]{3}{*}{ Criação do site } & 01 & $\mathrm{R} \$ 585,00$ & $R \$ 585,00$ \\
\hline & & TOTAL & $R \$ 1.185,00$ \\
\hline & & TOTAL GERAL & $R \$ 136.368,00$ \\
\hline
\end{tabular}


Tabela 9. Consolidação do Investimento inicial.

\begin{tabular}{|c|c|c|c|}
\hline & & \\
\hline & & Valor $(\mathbf{R} \$)$ & $\%$ \\
\hline \multicolumn{2}{|c|}{ Despesas Pré-Operacionais } & $1.519,00$ & $0,9 \%$ \\
\hline \multicolumn{2}{|c|}{ Investimentos Fixos } & $136.638,00$ & $78,5 \%$ \\
\hline Capital de Giro & Valor (R\$) & $35.850,27$ & $20,6 \%$ \\
\hline Custo Fixo & $6.747,05$ & & \\
\hline Matéria-Prima & $4.103,22$ & & \\
\hline Reserva Financei & $25.000,00$ & & \\
\hline \multicolumn{2}{|c|}{ TOTAL DO INVESTIMENTO INICIAL } & $174.007,27$ & $100,0 \%$ \\
\hline
\end{tabular}

Os valores apresentados em serviços contábeis são destinados à abertura de firma, fornecidos por contador local; os valores apresentados em mobília e instalação da internet foram pesquisados diretamente com fornecedores e lojas comerciais da cidade; os valores destinados às obras da propriedade foram baseados nos preços cobrados por profissionais da área na cidade de Formosa/GO.

\section{b) Desembolsos operacionais:}

O custo mensal da empresa Fazenda Hotel Rancho Grande está apresentado a seguir:

- Remuneração e encargos:

Conforme dados sugeridos por um contador da cidade de Formosa/GO, os salários e encargos são descritos da seguinte forma:

Tabela 10. Remunerações e encargos para o ano 1.

\begin{tabular}{|l|l|l|l|l|l|}
\hline Despesas com pessoal & $\begin{array}{l}\text { Encargos } \\
\text { FGTS (\%) }\end{array}$ & $\begin{array}{l}\text { Encargos } \\
\text { INSS (\%) }\end{array}$ & $\begin{array}{l}\text { Remuneração } \\
\text { mensal (R\$) }\end{array}$ & $\begin{array}{l}\text { Encargos para } \\
\text { a empresa (R\$) }\end{array}$ & $\begin{array}{l}\text { Encargos } \\
\text { funcionário } \\
\text { (R\$) }\end{array}$ \\
\hline $\begin{array}{l}\text { Sócio Gerente Administrativo } \\
\text { / Comercial / Financeiro }\end{array}$ & & $11 \%$ & $\mathrm{R} \$ 485,00$ & & $\mathrm{R} \$ 53,35$ \\
\hline Sócio Gerente Funcional & & $11 \%$ & $\mathrm{R} \$ 485,00$ & & $\mathrm{R} \$ 53,35$ \\
\hline Copeira & $8 \%$ & $4 \%$ & $\mathrm{R} \$ 600,00$ & $\mathrm{R} \$ 48,00$ & $\mathrm{R} \$ 24,00$ \\
\hline Camareira & $8 \%$ & $4 \%$ & $\mathrm{R} \$ 600,00$ & $\mathrm{R} \$ 48,00$ & $\mathrm{R} \$ 24,00$ \\
\hline Guia de Turismo & $8 \%$ & $7,65 \%$ & $\mathrm{R} \$ 800,00$ & $\mathrm{R} \$ 64,00$ & $\mathrm{R} \$ 61,20$ \\
\hline Total Geral remuneração + encargos para a empresa = R\$ 2.160,00 & & \\
\hline
\end{tabular}


Tabela 11. Remunerações e encargos para o ano 2.

\begin{tabular}{|l|l|l|l|l|l|}
\hline Despesas com pessoal & $\begin{array}{l}\text { Encargos } \\
\text { FGTS (\%) }\end{array}$ & $\begin{array}{l}\text { Encargos } \\
\text { INSS (\%) }\end{array}$ & $\begin{array}{l}\text { Remuneração } \\
\text { mensal (R\$) }\end{array}$ & $\begin{array}{l}\text { Encargos para } \\
\text { a empresa (R\$) }\end{array}$ & $\begin{array}{l}\text { Encargos } \\
\text { funcionário } \\
\text { (R\$) }\end{array}$ \\
\hline $\begin{array}{l}\text { Sócio Gerente Administrativo } \\
\text { / Comercial / Financeiro }\end{array}$ & & $11 \%$ & $\mathrm{R} \$ 485,00$ & & $\mathrm{R} \$ 53,35$ \\
\hline Sócio Gerente Funcional & & $11 \%$ & $\mathrm{R} \$ 485,00$ & & $\mathrm{R} \$ 53,35$ \\
\hline Copeira & $8 \%$ & $4 \%$ & $\mathrm{R} \$ 650,00$ & $\mathrm{R} \$ 52,00$ & $\mathrm{R} \$ 26,00$ \\
\hline Camareira & $8 \%$ & $4 \%$ & $\mathrm{R} \$ 650,00$ & $\mathrm{R} \$ 52,00$ & $\mathrm{R} \$ 26,00$ \\
\hline Guia de Turismo & $8 \%$ & $7,65 \%$ & $\mathrm{R} \$ 850,00$ & $\mathrm{R} \$ 68,00$ & $\mathrm{R} \$ 65,03$ \\
\hline Estagiário & \multicolumn{4}{|l|}{$\mathrm{R} \$ 400,00$} & \\
\hline Total Geral remuneração + encargos para a empresa = R\$ 2.722,00 & \\
\hline
\end{tabular}

Tabela 12. Remunerações e encargos para o ano 3.

\begin{tabular}{|l|l|l|l|l|l|}
\hline Despesas com pessoal & $\begin{array}{l}\text { Encargos } \\
\text { FGTS (\%) }\end{array}$ & $\begin{array}{l}\text { Encargos } \\
\text { INSS (\%) }\end{array}$ & $\begin{array}{l}\text { Remuneração } \\
\text { mensal (R\$) }\end{array}$ & $\begin{array}{l}\text { Encargos para } \\
\text { a empresa (R\$) }\end{array}$ & $\begin{array}{l}\text { Encargos } \\
\text { funcionário } \\
\text { (R\$) }\end{array}$ \\
\hline $\begin{array}{l}\text { Sócio Gerente Administrativo } \\
\text { / Comercial / Financeiro }\end{array}$ & & $11 \%$ & $\mathrm{R} \$ 485,00$ & & $\mathrm{R} \$ 53,35$ \\
\hline Sócio Gerente Funcional & & $11 \%$ & $\mathrm{R} \$ 485,00$ & & $\mathrm{R} \$ 53,35$ \\
\hline Copeira & $8 \%$ & $7,65 \%$ & $\mathrm{R} \$ 700,00$ & $\mathrm{R} \$ 56,00$ & $\mathrm{R} \$ 53,55$ \\
\hline Camareira 1 & $8 \%$ & $7,65 \%$ & $\mathrm{R} \$ 700,00$ & $\mathrm{R} \$ 56,00$ & $\mathrm{R} \$ 53,55$ \\
\hline Camareira 2 & $8 \%$ & $7,65 \%$ & $\mathrm{R} \$ 700,00$ & $\mathrm{R} \$ 56,00$ & $\mathrm{R} \$ 53,55$ \\
\hline Guia de Turismo & $8 \%$ & $\mathbf{9} \%$ & $\mathrm{R} \$ 900,00$ & $\mathrm{R} \$ 72,00$ & $\mathrm{R} \$ 81,00$ \\
\hline Estagiário & \multicolumn{2}{l|}{$\mathrm{R} \$ 400,00$} & & \\
\hline Total Geral remuneração + encargos para a empresa = R\$ 3.640,00 & & \\
\hline
\end{tabular}

Tabela 13. Remunerações e encargos para o ano 4.

\begin{tabular}{|l|l|l|l|l|l|}
\hline Despesas com pessoal & $\begin{array}{l}\text { Encargos } \\
\text { FGTS (\%) }\end{array}$ & $\begin{array}{l}\text { Encargos } \\
\text { INSS (\%) }\end{array}$ & $\begin{array}{l}\text { Remuneração } \\
\text { mensal (R\$) }\end{array}$ & $\begin{array}{l}\text { Encargos para } \\
\text { a empresa (R\$) }\end{array}$ & $\begin{array}{l}\text { Encargos } \\
\text { funcionário } \\
\text { (R\$) }\end{array}$ \\
\hline $\begin{array}{l}\text { Sócio Gerente Administrativo } \\
\text { / Comercial / Financeiro }\end{array}$ & & $11 \%$ & $\mathrm{R} \$ 485,00$ & & $\mathrm{R} \$ 53,35$ \\
\hline Sócio Gerente Funcional & & $11 \%$ & $\mathrm{R} \$ 485,00$ & & $\mathrm{R} \$ 53,35$ \\
\hline Copeira & $8 \%$ & $7,65 \%$ & $\mathrm{R} \$ 750,00$ & $\mathrm{R} \$ 60,00$ & $\mathrm{R} \$ 57,38$ \\
\hline Camareira 1 & $8 \%$ & $7,65 \%$ & $\mathrm{R} \$ 750,00$ & $\mathrm{R} \$ 60,00$ & $\mathrm{R} \$ 57,38$ \\
\hline Camareira 2 & $8 \%$ & $7,65 \%$ & $\mathrm{R} \$ 750,00$ & $\mathrm{R} \$ 60,00$ & $\mathrm{R} \$ 57,38$ \\
\hline Guia de Turismo 1 & $8 \%$ & $9 \%$ & $\mathrm{R} \$ 950,00$ & $\mathrm{R} \$ 76,00$ & $\mathrm{R} \$ 85,50$ \\
\hline Guia de Turismo 2 & $8 \%$ & $\mathrm{R} \$ 950,00$ & $\mathrm{R} \$ 76,00$ & $\mathrm{R} \$ 85,50$ \\
\hline Estagiário & $9 \%$ & & \\
\hline Total Geral remuneração + encargos para a empresa = R\$ 4.932,00 & \\
\hline
\end{tabular}

Tabela 14. Remunerações e encargos para $o$ ano 5.

\begin{tabular}{|l|l|l|l|l|l|}
\hline Despesas com pessoal & $\begin{array}{l}\text { Encargos } \\
\text { FGTS (\%) }\end{array}$ & $\begin{array}{l}\text { Encargos } \\
\text { INSS (\%) }\end{array}$ & $\begin{array}{l}\text { Remuneração } \\
\text { mensal (R\$) }\end{array}$ & $\begin{array}{l}\text { Encargos para } \\
\text { a empresa (R\$) }\end{array}$ & $\begin{array}{l}\text { Encargos } \\
\text { funcionário } \\
\text { (R\$) }\end{array}$ \\
\hline $\begin{array}{l}\text { Sócio Gerente Administrativo } \\
\text { / Comercial / Financeiro }\end{array}$ & & $11 \%$ & $\mathrm{R} \$ 485,00$ & & $\mathrm{R} \$ 53,35$ \\
\hline Sócio Gerente Funcional & & $11 \%$ & $\mathrm{R} \$ 485,00$ & & $\mathrm{R} \$ 53,35$ \\
\hline Copeira & $8 \%$ & $7,65 \%$ & $\mathrm{R} \$ 800,00$ & $\mathrm{R} \$ 64,00$ & $\mathrm{R} \$ 61,20$ \\
\hline Camareira 1 & $8 \%$ & $7,65 \%$ & $\mathrm{R} \$ 800,00$ & $\mathrm{R} \$ 64,00$ & $\mathrm{R} \$ 61,20$ \\
\hline Camareira 2 & $8 \%$ & $7,65 \%$ & $\mathrm{R} \$ 800,00$ & $\mathrm{R} \$ 64,00$ & $\mathrm{R} \$ 61,20$ \\
\hline Guia de Turismo 1 & $8 \%$ & $9 \%$ & $\mathrm{R} \$ 1.000,00$ & $\mathrm{R} \$ 80,00$ & $\mathrm{R} \$ 90,00$ \\
\hline Guia de Turismo 2 & $8 \%$ & $\mathrm{R} \$ 1.000,00$ & $\mathrm{R} \$ 80,00$ & $\mathrm{R} \$ 90,00$ \\
\hline Estagiário & $\mathbf{9 \%}$ & $\mathrm{R} \$ 500,00$ & & \\
\hline Total Geral remuneração + encargos para a empresa = R\$ 5.252,00 \\
\hline
\end{tabular}


Os gerentes receberão o pró-labora de $R \$ 485,00$ e pagarão $R \$ 53,35$ de INSS cada. Essa alternativa foi escolhida com a intenção de minimizar os gastos, pois são sócios e receberão o lucro distribuído da empresa. Observa-se que o total geral de remuneração e encargos exclui os salários da gerência.

As despesas mensais estão demonstradas a seguir:

Tabela 15. Despesas mensais para o ano 1.

\begin{tabular}{|l|l|}
\hline Despesas Mensais & Valor $\mathbf{R} \mathbf{\text { ) }}$ \\
\hline Telefone + internet & $\mathrm{R} \$ 200,00$ \\
\hline Energia & $\mathrm{R} \$ 385,00$ \\
\hline Despesa com combustível & $\mathrm{R} \$ 455,00$ \\
\hline Despesa pessoal com encargos & $\mathrm{R} \$ 1.142,22$ \\
\hline Manutenção do site & $\mathrm{R} \$ 58,00$ \\
\hline Material de escritório & $\mathrm{R} \$ 50,00$ \\
\hline Contador & $\mathrm{R} \$ 100,00$ \\
\hline Despesas operacionais & $\mathrm{R} \$ 120,00$ \\
\hline TOTAL & $\mathbf{R} \mathbf{2 . 5 1 0 , 2 2}$ \\
\hline
\end{tabular}

Tabela 16. Despesas mensais para o ano 2.

\begin{tabular}{|l|l|}
\hline Despesas Mensais & Valor $\mathbf{R} \$ \mathbf{)}$ \\
\hline Telefone + internet & $\mathrm{R} \$ 250,00$ \\
\hline Energia & $\mathrm{R} \$ 385,00$ \\
\hline Despesa com combustível & $\mathrm{R} \$ 455,00$ \\
\hline Despesa pessoal com encargos & $\mathrm{R} \$ 1.205,39$ \\
\hline Manutenção do site & $\mathrm{R} \$ 58,00$ \\
\hline Material de escritório & $\mathrm{R} \$ 50,00$ \\
\hline Contador & $\mathrm{R} \$ 100,00$ \\
\hline Despesas operacionais & $\mathrm{R} \$ 120,00$ \\
\hline TOTAL & $\mathbf{R} \mathbf{2 . 6 2 3 , 3 9}$ \\
\hline
\end{tabular}

Tabela 17. Despesas mensais para o ano 3.

\begin{tabular}{|l|l|}
\hline Despesas Mensais & Valor $\mathbf{R} \$ \mathbf{)}$ \\
\hline Telefone + internet & $\mathrm{R} \$ 280,00$ \\
\hline Energia & $\mathrm{R} \$ 385,00$ \\
\hline Despesa com combustível & $\mathrm{R} \$ 455,00$ \\
\hline Despesa pessoal com encargos & $\mathrm{R} \$ 1.942,33$ \\
\hline Manutenção do site & $\mathrm{R} \$ 58,00$ \\
\hline Material de escritório & $\mathrm{R} \$ 50,00$ \\
\hline Contador & $\mathrm{R} \$ 100,00$ \\
\hline Despesas operacionais & $\mathrm{R} \$ 120,00$ \\
\hline TOTAL & $\mathbf{R} \$ \mathbf{3 . 3 9 0 , 3 3}$ \\
\hline
\end{tabular}


Tabela 18. Despesas mensais para o ano 4.

\begin{tabular}{|l|l|}
\hline Despesas Mensais & Valor $\mathbf{R} \$$ ) \\
\hline Telefone + internet & $\mathrm{R} \$ 300,00$ \\
\hline Energia & $\mathrm{R} \$ 385,00$ \\
\hline Despesa com combustível & $\mathrm{R} \$ 455,00$ \\
\hline Despesa pessoal com encargos & $\mathrm{R} \$ 2.047,61$ \\
\hline Manutenção do site & $\mathrm{R} \$ 60,00$ \\
\hline Material de escritório & $\mathrm{R} \$ 60,00$ \\
\hline Contador & $\mathrm{R} \$ 110,00$ \\
\hline Despesas operacionais & $\mathrm{R} \$ 120,00$ \\
\hline TOTAL & $\mathbf{R} \$ \mathbf{3 . 5 3 7 , 6 1}$ \\
\hline
\end{tabular}

Tabela 19. Despesas mensais para o ano 5.

\begin{tabular}{|l|l|}
\hline Despesas Mensais & Valor $\mathbf{R} \$$ ) \\
\hline Telefone + internet & $\mathrm{R} \$ 300,00$ \\
\hline Energia & $\mathrm{R} \$ 385,00$ \\
\hline Despesa com combustível & $\mathrm{R} \$ 455,00$ \\
\hline Despesa pessoal com encargos & $\mathrm{R} \$ 1.394,89$ \\
\hline Manutenção do site & $\mathrm{R} \$ 60,00$ \\
\hline Material de escritório & $\mathrm{R} \$ 60,00$ \\
\hline Contador & $\mathrm{R} \$ 110,00$ \\
\hline Despesas operacionais & $\mathrm{R} \$ 130,00$ \\
\hline TOTAL & $\mathbf{R} \$ \mathbf{2 . 8 9 4 , 8 9}$ \\
\hline
\end{tabular}

\section{c) Faturamento:}

O faturamento mensal da empresa foi desenvolvido considerando a seguinte projeção de vendas:

Tabela 20. Faturamento mensal da empresa.

\begin{tabular}{|c|c|c|c|c|c|c|c|c|c|c|c|c|}
\hline Ano 1 & $\begin{array}{l}\text { Mês } \\
1\end{array}$ & $\begin{array}{l}\text { Mês } \\
2\end{array}$ & $\begin{array}{l}\text { Mês } \\
3\end{array}$ & $\begin{array}{l}\text { Mês } \\
4\end{array}$ & $\begin{array}{l}\text { Mês } \\
5\end{array}$ & $\begin{array}{l}\text { Mês } \\
6\end{array}$ & $\begin{array}{l}\text { Mês } \\
7\end{array}$ & $\begin{array}{l}\text { Mês } \\
8\end{array}$ & $\begin{array}{l}\text { Mês } \\
9\end{array}$ & $\begin{array}{l}\text { Mês } \\
10\end{array}$ & $\begin{array}{l}\text { Mês } \\
11\end{array}$ & $\begin{array}{l}\text { Mês } \\
12\end{array}$ \\
\hline Hospedagem & 110 & 125 & 100 & 100 & 100 & 127 & 150 & 127 & 135 & 135 & 127 & 175 \\
\hline Ano 2 & $\begin{array}{l}\text { Mês } \\
1\end{array}$ & $\begin{array}{l}\text { Mês } \\
2\end{array}$ & $\begin{array}{l}\text { Mês } \\
3\end{array}$ & $\begin{array}{l}\text { Mês } \\
4\end{array}$ & $\begin{array}{l}\text { Mês } \\
5\end{array}$ & $\begin{array}{l}\text { Mês } \\
6\end{array}$ & $\begin{array}{l}\text { Mês } \\
7\end{array}$ & $\begin{array}{l}\text { Mês } \\
8\end{array}$ & $\begin{array}{l}\text { Mês } \\
9\end{array}$ & $\begin{array}{l}\text { Mês } \\
10\end{array}$ & $\begin{array}{l}\text { Mês } \\
11\end{array}$ & $\begin{array}{l}\text { Mês } \\
12\end{array}$ \\
\hline Hos & 121 & 137 & 110 & 110 & 110 & 139 & 165 & 139 & 148 & 148 & 139 & 192 \\
\hline Ano 3 & $\begin{array}{l}\text { Mês } \\
1\end{array}$ & $\begin{array}{l}\text { Mês } \\
2\end{array}$ & $\begin{array}{l}\text { Mês } \\
3\end{array}$ & $\begin{array}{l}\text { Mês } \\
4\end{array}$ & $\begin{array}{l}\text { Mês } \\
5\end{array}$ & $\begin{array}{l}\text { Mês } \\
6\end{array}$ & $\begin{array}{l}\text { Mês } \\
7\end{array}$ & $\begin{array}{l}\text { Mês } \\
8\end{array}$ & $\begin{array}{l}\text { Mês } \\
9\end{array}$ & $\begin{array}{l}\text { Mês } \\
10\end{array}$ & $\begin{array}{l}\text { Mês } \\
11\end{array}$ & $\begin{array}{l}\text { Mês } \\
12\end{array}$ \\
\hline Hos & 133 & 140 & 121 & 121 & 121 & 163 & 181 & 163 & 162 & 162 & 163 & 211 \\
\hline Ano 4 & $\begin{array}{l}\text { Mês } \\
1\end{array}$ & $\begin{array}{l}\text { Mês } \\
2\end{array}$ & $\begin{array}{l}\text { Mês } \\
3\end{array}$ & $\begin{array}{l}\text { Mês } \\
4\end{array}$ & $\begin{array}{l}\text { Mês } \\
5\end{array}$ & $\begin{array}{l}\text { Mês } \\
6\end{array}$ & $\begin{array}{l}\text { Mês } \\
7\end{array}$ & $\begin{array}{l}\text { Mês } \\
8\end{array}$ & $\begin{array}{l}\text { Mês } \\
9\end{array}$ & $\begin{array}{l}\text { Mês } \\
10\end{array}$ & $\begin{array}{l}\text { Mês } \\
11\end{array}$ & $\begin{array}{l}\text { Mês } \\
12\end{array}$ \\
\hline Hos & 146 & 154 & 133 & 133 & 133 & 179 & 199 & 179 & 176 & 176 & 179 & 232 \\
\hline Anc & $\begin{array}{l}\text { Mês } \\
1\end{array}$ & $\begin{array}{l}\text { Mês } \\
2\end{array}$ & $\begin{array}{l}\text { Mês } \\
3\end{array}$ & $\begin{array}{l}\text { Mês } \\
4\end{array}$ & $\begin{array}{l}\text { Mês } \\
5\end{array}$ & $\begin{array}{l}\text { Mês } \\
6\end{array}$ & $\begin{array}{l}\text { Mês } \\
7\end{array}$ & $\begin{array}{l}\text { Mês } \\
8\end{array}$ & \begin{tabular}{|l} 
Mêss \\
9
\end{tabular} & $\begin{array}{l}\text { Mês } \\
10\end{array}$ & $\begin{array}{l}\text { Mês } \\
11\end{array}$ & $\begin{array}{l}\text { Mês } \\
12\end{array}$ \\
\hline Hospedagem & 160 & 169 & 146 & 146 & 146 & 197 & 219 & 197 & 193 & 193 & 197 & 255 \\
\hline
\end{tabular}


A projeção de vendas é de 10\% (dez por cento) ao ano em relação ao mês que se estuda. Essa projeção foi desenvolvida aleatoriamente levando em consideração alguns momentos de sazonalidade como férias escolares e feriados.

\section{d) Fluxo de caixa:}

O fluxo de caixa foi elaborado a partir da projeção de vendas de $10 \%$ (dez por cento) ao ano em relação ao mês em estudo, e está apresentado no apêndice D.

\section{e) Indicadores:}

- Taxa Interna de Retorno (TIR): conforme a tabela de fluxo de caixa apresentada no apêndice D, é apresentada a TIR de $19,32 \%$ ao ano, ou seja, o investimento está sendo remunerado a $19,32 \%$ ao ano, portanto é demonstrada a viabilidade do negócio, uma vez que a TIR apresenta um valor maior ao valor da taxa de juros que é de $14 \%$ ao ano.

- Ponto de Equilíbrio:

Tabela 21. Projeção de custos fixos e variáveis da empresa.

\begin{tabular}{|l|c|c|c|c|c|}
\hline \multicolumn{1}{|c|}{ DESCRIÇÃO } & MÊS 1/ANO1 & MÊS 1/ANO2 & MÊS 1/ANO3 & MÊS 1/ANO4 & MÊS $1 /$ ANO5 \\
\hline CUSTO VARIÁVEL & $\mathrm{R} \$ 5.049,00$ & $\mathrm{R} \$ 6.040,47$ & $\mathrm{R} \$ 9.649,72$ & $\mathrm{R} \$ 10.694,33$ & $\mathrm{R} \$ 9.212,73$ \\
\hline CUSTO FIXO & $\mathrm{R} \$ 6.613,07$ & $\mathrm{R} \$ 7.977,13$ & $\mathrm{R} \$ 10.029,86$ & $\mathrm{R} \$ 12.732,23$ & $\mathrm{R} \$ 16.273,19$ \\
\hline CUSTOS TOTAIS & $\mathrm{R} \$ 11.662,08$ & $\mathrm{R} \$ 14.017,60$ & $\mathrm{R} \$ 19.679,58$ & $\mathrm{R} \$ 23.426,56$ & $\mathrm{R} \$ 25.485,92$ \\
\hline QUANTIDADE & 130 & 143 & 157 & 173 & 190 \\
\hline CUSTO UNITÁRIO & $\mathrm{R} \$ 89,71$ & $\mathrm{R} \$ 98,03$ & $\mathrm{R} \$ 125,11$ & $\mathrm{R} \$ 135,39$ & $\mathrm{R} \$ 133,90$ \\
\hline PREÇO DESEJADO & $\mathrm{R} \$ 150,00$ & $\mathrm{R} \$ 155,00$ & $\mathrm{R} \$ 160,00$ & $\mathrm{R} \$ 165,00$ & $\mathrm{R} \$ 170,00$ \\
\hline MARGEM BRUTA & $67 \%$ & $58 \%$ & $28 \%$ & $22 \%$ & $27 \%$ \\
\hline
\end{tabular}

Para se calcular o ponto de equilíbrio (PQ) para um produto, a hospedagem, devese fazer os seguintes cálculos:

$P Q=\frac{F}{M C}$ onde $F$ é o custo fixo total, e $M C$ é a margem de contribuição.

A margem de contribuição e o ponto de equilíbrio podem ser observados na tabela 18, onde a margem de contribuição é a diferença entre o preço de venda e o custo variável por unidade. 
Tabela 22. Margem de contribuição e ponto de equilíbrio.

\begin{tabular}{|l|c|c|c|c|c|}
\hline \multirow{2}{*}{ DESCRIÇÃO } & \multicolumn{4}{|c|}{ QUANTIDADES MENSAIS DE VENDAS - ANO 1, ANO 2, ANO 3, ANO 4, ANO 5 } \\
\cline { 2 - 6 } & 130 & 143 & 157 & 173 \\
\hline PREÇO DE VENDA & $\mathrm{R} \$ 150,00$ & $\mathrm{R} \$ 155,00$ & $\mathrm{R} \$ 160,00$ & $\mathrm{R} \$ 165,00$ & $\mathrm{R} \$ 170,00$ \\
\hline CUSTO VARIÁVEL POR UNIDADE & $\mathrm{R} \$ 38,84$ & $\mathrm{R} \$ 42,24$ & $\mathrm{R} \$ 61,35$ & $\mathrm{R} \$ 61,81$ & $\mathrm{R} \$ 48,40$ \\
\hline MARGEM DE CONTRIBUIÇÃO UNITÁRIA & $\mathrm{R} \$ 111,16$ & $\mathrm{R} \$ 112,76$ & $\mathrm{R} \$ 98,65$ & $\mathrm{R} \$ 103,19$ & $\mathrm{R} \$ 121,60$ \\
\hline CUSTO FIXO TOTAL & $\mathrm{R} \$ 6.613,07$ & $\mathrm{R} \$ 7.977,13$ & $\mathrm{R} \$ 10.029,86$ & $\mathrm{R} \$ 12.732,23$ & $\mathrm{R} \$ 16.273,19$ \\
\hline PONTO DE EQUILÍBRIO EM UNIDADES & 59 & 71 & 102 & 123 & 134 \\
\hline ÍNDICE DE MARGEM DE CONTRIBUIÇÃO & 0,74 & 0,73 & 0,62 & 0,63 & 0,72 \\
\hline PONTO DE EQUILÍBRIO MONETÁRIO & $\mathrm{R} \$ 8.923,60$ & $\mathrm{R} \$ 10.965,47$ & $\mathrm{R} \$ 16.266,72$ & $\mathrm{R} \$ 20.357,99$ & $\mathrm{R} \$ 22.750,94$ \\
\hline CUSTO VARIÁVEL NO PEQ & $\mathrm{R} \$ 2.310,53$ & $\mathrm{R} \$ 2.988,34$ & $\mathrm{R} \$ 6.236,86$ & $\mathrm{R} \$ 7.625,76$ & $\mathrm{R} \$ 6.477,76$ \\
\hline
\end{tabular}

O ponto de equilíbrio em unidades é a quantidade mínima de produtos a serem vendidos para cobrir todos os gastos da empresa, ou seja, não haverá lucro nem prejuízo. O índice de margem de contribuição é o valor percentual, sobre o preço de venda, com que cada produto ou serviço contribui para saldar o custo fixo da empresa. O ponto de equilíbrio monetário é o valor de faturamento que a empresa precisa obter com as suas vendas para cobrir todos os gastos da empresa, ou seja, nem lucro e nem prejuízo.

- Período de payback (tempo de retorno): o tempo de retorno do investimento inicial é de 5 anos conforme tabela abaixo.

Tabela 23. Payback.

\begin{tabular}{|l|c|}
\hline \multicolumn{2}{|l|}{ PRAZO DE RECUPERAÇÃO ECONÔMICA } \\
\hline FCL ANO1 & $69.687,01$ \\
\hline FCL ANO2 & $58.093,14$ \\
\hline FCL ANO3 & $26.123,37$ \\
\hline FCL ANO4 & $17.213,17$ \\
\hline FCL ANO5 & $21.686,46$ \\
\hline INVESTIMENTO & $174.007,27$ \\
\hline FCL MÉDIO & $38.560,63$ \\
\hline PRE/ANO & 4,51 \\
\hline
\end{tabular}




\section{CONSIDERAÇÕES FINAIS}

Identificou-se que o turismo rural é uma atividade que se desenvolve no meio rural associada às atividades agropecuárias da propriedade, aqui, da Fazenda Rancho Grande objeto de estudo desse trabalho de conclusão de especialização. Observase que a montagem do hotel na fazenda não vem a se tornar a atividade principal e sim agregar valor a atividade turística associada às atividades agropecuárias da propriedade.

Por se tratar de uma atividade que acontece na natureza deve-se preocupar com a sustentabilidade do local para que gerações futuras possam experenciar as atividades que aqui possam vir a ser desenvolvidas como trilhas e banho de rio.

Para que o turismo rural seja implementado na Fazenda Rancho Grande, faz-se necessário um planejamento turístico com um plano de negócios para que a atividade aconteça de forma sustentável e agregada às atividades agropecuárias da propriedade, pois é um saber conhecer os fatos, saber observar, ser objetivo e saber admitir possíveis erros para serem bem administrados.

Nesse trabalho foi feita uma análise financeira, para que possa mostrar o potencial da atividade turística, porém, para que a atividade venha a ser implementada é necessário que esse estudo seja continuado através da identificação das necessidades de reforma e implementação de equipamentos turísticos trazendo segurança e preservação do meio ambiente, feita de acordo com as propostas definidas pelo diagnóstico e prognóstico, fases fundamentais do planejamento turístico. Essas propostas podem ser desenvolvidas a médio e longo prazos.

O planejamento financeiro é uma condição necessária para alavancar o sucesso empresarial. É preciso ser profissional e estar atento a variações da economia e política, local e global, mas também em mercados externos, prever dificuldades inerentes a estes questionamentos e formular uma política empresarial que atenda a todos estes fatores levando a empresa a ter um crescimento homogêneo e constante.

Tem-se como um dos objetivos do planejamento financeiro desenvolver uma relação harmoniosa entre o crescimento da empresa com a necessidade de 
produção para dar sustentação à mesma, necessidade de investimentos externos, previsão de pagamentos de dívidas e impostos, salários, estimativas de custos da produção entre outras, com o intuito de prover a empresa de recursos financeiros.

Após a análise dos dados apresentados, é possível perceber que os objetivos, geral e específicos, foram alcançados e que a hipótese correta para esse trabalho de conclusão de curso, onde, após a análise dos dados, aparentemente é viável a implementação do empreendimento na propriedade. 


\section{REFERÊNCIAS}

ADA INTERNET. Formosa online. 1aㅡ ed. Goiás: Ada Internet, 2008. Disponível em: <http://www.formosaonline.com.br>. Acesso em: 22 de Mai. de 2009.

AECOTURIS. Meio ambiente: ecoglossário. $1^{\underline{a}}$ ed. Brasil: Aecoturis, 2008. Disponível em: <http:// www.viajemaisbrasil.com.br/glossario.php\#a5>. Acesso em: 22 Abr. 2008.

ANSARAH, Marília Gomes dos Reis. Como aprender turismo, como ensinar: volume 2. $2^{\mathrm{a}}$ ed. São Paulo: SENAC São Paulo, 2001. p. 71.

BARRETTO, Margarita. Planejamento e organização em turismo. $8^{\text {a }}$ ed. Campinas: Papirus, 2003. p. 12 a 16.

BERNARDI, Luiz Antonio. Manual de plano de negócios. 1a ed. São Paulo: Atlas, 2007. p. 109 a 183.

CHIAVENATO, Idalberto. Administração Geral e Pública. $2^{\underline{a}}$ ed. Rio de Janeiro: Campus, 2008. p. 418.

COOPER, Chris (Org.). Turismo: princípios e práticas. $2^{\underline{a}}$ ed. Porto Alegre: Bookman, 2001. p. 246.

COSTA, José Santana; AMBRÓSIO, Tânia Mara. Plano de Negócio - Pousada Interiorana.1ํㅡㄹ ed. Rio Grande do Norte: SEBRAE, 2004. p. 5 a 25.

COSTA, Patrícia Côrtes. Ecoturismo. 2ª ed. São Paulo: Aleph, 2002. p. 31.

DENCKER, Ada de Freitas M. Métodos e técnicas de pesquisa em turismo. $6^{\text {a }}$ ed. São Paulo: Futura, 2002. p. 17 a 135.

DOLABELA, Fernando. Luísa. 15ํㅡㄹ ed. São Paulo: Editores Associados, 2006. p. 76 a 186.

EMATER, Cartilha do agroturismo. $1^{\text {a }}$ ed. Vitória: Emater, 1998. p. 10.

EMBRATUR. Manual Operacional do Turismo Rural. $1^{\text {a }}$ ed. Brasília: Embratur, 1994. p. 08.

FACHIN, Odília. Fundamentos de Metodologia. 3aㅡ ed. São Paulo: Saraiva, 2002. p. 25 a 55. 
GOOGLE. Google Maps Brasil. $1^{\underline{a}}$ ed. Brasil: Google, 2008. Disponível em: <http://maps.google.com.br/>. Acesso em: 22 de Mai. de 2009.

KOOGAN, Abrahão; HOUAISS, Antônio. Enciclopédia e dicionário ilustrado. $4^{\underline{a}}$ ed. Rio de Janeiro: Seifer, 2000. p. 1130 e 1420.

LAGE, Beatriz Helena G.; MILONE, Paulo César. Economia do Turismo. $7^{a}$ ed. São Paulo: Atlas, 2001. p. 56 a 88.

LAKATOS, Eva Maria; MARCONI, Marina de Andrade. Fundamentos de Metodologia Científica. 4⿳亠丷a ed. São Paulo: Atlas, 2001. p. 83 a 112.

LUCION, Carlos Eduardo Rosa. Revista Eletrônica de Contabilidade - Curso de Ciências Contábeis da Universidade Federal de Santa Maria: Planejamento financeiro. Santa Maria: UFSM, 2005, Volume 1, n³. p. 143 e 144.

MINISTÉRIO DO TURISMO. Segmentação: Turismo - marcos conceituais. $1^{\text {a }}$ ed. Brasília: Ministério do Turismo, 2006. p. 1 e 49.

OLIVEIRA, Djalma de Pinho R. Planejamento Estratégico. 23a ed. São Paulo: Atlas, 2007. p. 3 a 6; p. 17 a 19; p. 37 e 38; p. 320 e 321.

OLIVO, Silvio. Como planejar sua empresa: riscos do negócio, roteiro para o plano de negócio. $2^{\mathrm{a}}$ ed. Brasília: SEBRAE, 2003. p. 14 a 25.

OMT. Turismo. $1^{\mathrm{a}}$ ed. Brasil: OMT, 2009. Disponível em: <http://www.omt.com.br>. Acesso em: 19 Mai. 2009.

PAIXÃO, Dário Luiz Dias. Plano de Negócios - Empresa: Recanto Verde Lodge. 1aㅡ ed. Paraná: Recanto Verde, 2002. p. 4 a 47.

PAVANI, Cláudia; DEUTSCHER, José Arnaldo; LÓPEZ, Santiago Maya. Plano de negócios: planejando o sucesso do seu empreendimento. $1^{\underline{a}}$ ed. Rio de Janeiro: Minion, 2000. p. 11 a 104.

RIBEIRO JÚNIOR, J. I. Noções de técnicas de amostragem. $1^{\underline{a}}$ ed. Viçosa: UFV, 2009.

em: <http://www.dpi.ufv.br/disciplinas/inf162/materiais/CAPITULO8.pdf>. Acesso em:1 Jun. 2009. 
ROCHA, Larissa Uchôa; LOPES, Alane de Queiroz. Trabalho de Conclusão de Curso: Turismo rural e ecoturismo - projeto para implementação de hotel na Fazenda Rancho Grande. Brasília: IESB, 2008.

ROSA, Cláudio Afrânio. Como elaborar um plano de negócios. 1aㅡ ed. Brasília: SEBRAE, 2007. p. 07 a 118.

SALIM, Cesar Simões; HOCHAN, Nelson; RAMAL, Andrea Cecília; RAMAL, Silvina Ana. Plano de negócios. 3를 ed. Rio de Janeiro: Elsevier, 2005. p. 03 a 127.

SALLES, Mary Mércia G. Turismo Rural. 1ª ed. São Paulo: Alinea, 2006. p. 57.

SEBRAE. Comece certo - Pousada. $1^{\text {a }}$ ed. São Paulo:SEBRAE, 2005. p. 11.

SENAC. Pousada: como montar e administrar. $1^{\text {a }}$ ed. Rio de Janeiro: Senac Nacional, 2007. p. 07.

SIRGADO, 2001. In SALLES, Mary Mércia G. Turismo rural: inventário turístico no meio rural. $2^{\underline{a}}$ ed. Campinas, SP: Alínea, 2006. p. 52.

SILVA, José Graziano; VILARINHO, Carlyle; DALE, Paul J. Turismo em áreas rurais: suas possibilidades e limitações no Brasil. In ALMEIDA, Joaquim Anécio; FROEHLICH, José Marcos; RIEDL, Mário (Orgs.). Turismo Rural e desenvolvimento sustentável. 3ª ed. Campinas, SP: Papirus, 2003. p. 47.

STIGLIANO, Beatriz Veroneze; BITTENCOURT CÉSAR, Pedro de Alcântara. Inventário Turístico. 1ㄹeㄹ. Campinas, SP: Alínea, 2005. p. 05.

TELÓ, Admir Roque. Desempenho organizacional: planejamento financeiro em empresas familiares. $1^{1}$ ed. Curitiba: Rev. FAE, 2001. p. 21 a 23.

TULIK, Olga. Turismo Rural. 1를 ed. São Paulo: Aleph, 2003. p. 34.

WEBCARTA. Webcarta: cartas online. $1^{\underline{a}}$ ed. Brasil: WebCarta, 2008. Disponível em: <http://webcarta.net/carta/mapa.php?id=6029\&lg=en>. Acesso em: 22 de Mai. de 2008. 


\section{ANEXO I}

Questionário aplicado em entrevista ao Sr. Carlos Magno Campos da Rocha, Proprietário da Fazenda Rancho Grande.

\section{A CARACTERIZAÇÃO DO EMPREENDIMENTO / FINANCIAMENTO.}

1. a. Razão social desse estabelecimento: R: FAZENDA RANCHO GRANDE

b. Nome de Fantasia: R: FAZENDA RANCHO GRANDE

2. Há quanto tempo esse estabelecimento está instalado nesse município?

$$
\text { R: VINTE E OITO ANOS }
$$

3. Quantos são os sócios proprietários desse estabelecimento?

R: APENAS UM O SR. CARLOS MAGNO CAMPOS DA ROCHA

4. Natureza desse estabelecimento?

(X) Estabelecimento único

( ) Matriz

( ) Estabelecimento de uma rede

( ) Outros

5. Que fatores influenciaram na decisão de compra esse estabelecimento nesse município?

( ) Facilidade em conseguir financiamento

( ) Alto potencial de atração de recursos

( ) Incentivo fiscais para instalação

( ) Possibilidade de lucro garantidos

( ) Facilidades de mão-de-obra

( ) Mercado potencial favorável

( ) Pólo de desenvolvimento de gado de elite.

(X) Outros..PAIXÃO PELA AGRONOMIA. 
6. Qual o valor inicial investido para instalação desse estabelecimento?

(X) Até 50 mil .REAIS

( ) Mais 50 até 100 mil.

( ) Mais de 100 até 200 mil

( ) Mais de 200 mil.

( ) Outros

7. O retorno do investimento tem correspondido às suas expectativas?

( ) Sim

(X) Não

( ) Em fase de implantação com expectativa de retorno positivo

( ) Outros

8. Conforme a importância no faturamento, indique as principais atividades desse estabelecimento?

( ) Central de transferência de embriões de gado de elite.

(X) Criação de gado de leite.

(X) Venda permanente de gado.

(X) Outros..PRODUÇÃO DE MILHO PARA ALIMENTAÇÃO DOS ANIMAIS.

9. Utilizou alguma linha de credito para o empreendimento?

(X) Sim

( ) Não

10. Qual origem dos créditos ou financiamentos utilizados

( ) Municipal

(X) Estadual

( ) Federal

( ) Internacional

11. Qual o tipo dos créditos ou financiamentos utilizados? 
R: CUSTEIO AGOPECUÁRIO (BB), FUNDO DE CENTRO-OESTE (FCO).

12. Para qual finalidade?

(X) Manutenção

( ) Ampliação

( ) Reforma

(X) Outros..COMPRA DE ANIMAIS DE LEITE.

13. Tem encontrado dificuldades para saldar a dívida?

(X) Sim

( ) Não

14. O que poderia ser feito para superar essa dificuldades?

( ) Maior carência

(X) Menores taxas de juros

( ) Diminuição da carga tributária

( ) Outros

INVESTIMENTOS

15. Em que tipos de investimentos têm sido aplicados os recursos advindos do seu lucro liquido?

( ) Na melhoria do próprio estabelecimento

( ) Em outros empreendimentos na região

( ) Em outros empreendimentos nesse município

(X) Outros..INFRA-ESTRUTURA BASICAMENTE

16. Nos próximos anos, o proprietário pretende fazer algum tipo de investimento nesse estabelecimento ou em outros negócios?

(X) Sim

( ) Não

17. Como pretende fazer este investimentos?

(X) Infra-Estrutura Turística na Fazenda Rancho Grande 
( ) Na localização da Fazenda

(X) Recursos Próprios com produção de leite

( ) Outros

18. Quais atividades têm potencial para investimentos nesse município?

(X) Hotéis

(X) Restaurantes

( ) Transporte de turismo

( ) Comércio de artesanato/ souvenier

( ) Outros

\section{AVALIAÇÃO DA ATIVIDADE TURISTICA}

19. Quais os tipos de turismo têm sido praticados neste município?

( ) Turismo de lazer

( ) Turismo de negócio

( ) Turismo de eventos

( ) Turismo de cultural

( ) Turismo religioso

(X) Turismo aventura

(X) Turismo ecológico

( ) Outros

20. Qual o predominante nesse município?

( ) Turismo de lazer

( ) Turismo de negócio

( ) Turismo de eventos

( ) Turismo de cultural

( ) Turismo religioso

(X) Turismo aventura 
(X) Turismo ecológico

( ) Outros..SALTO ITIQUIRA.

21. Como avalia o desenvolvimento da atividade turística nesse município?

( ) Muito desenvolvida

( ) Desenvolvida

(X) Pouco desenvolvida

(X) Outros..É MUITO LENDO E DESENVOLVIMENTO.......

22. Quais as perspectivas de desenvolvimento da atividade turística nesse município?

(X) Crescimento

( ) Estabilização

( ) Retração

23. Para qual tipo de turismo esse município apresenta maior potencial?

( ) Turismo de lazer

( ) Turismo de negócio

( ) Turismo de eventos

(X) Turismo de cultural

( ) Turismo religioso

(X) Turismo aventura

(X) Turismo ecológico

(X) Outros...TURISMO RURAL

24. Atualmente, como avalia o turismo no município quanto à geração de empregos?

( ) Atualmente gera muitos oportunidades de emprego

(X) Atualmente gera média oportunidades de emprego

( ) Atualmente gera pouca oportunidades de emprego

( ) Outros 
25. Como avalia o turismo no município quanto ao potencial para geração de empregos?

(X) Poderá gerar muitas oportunidades de emprego

( ) Poderá gerar algumas oportunidades de emprego

( ) Não tem potencial para gerar oportunidade de emprego

( ) Outros

26. Quais os principais atrativos naturais e culturais desse município?

R: NASCEM 47 RIOS EM FORMOSA

27. Como avalia o potencial dos recursos naturais e culturais desse município quanto à possibilidade de constituírem atrativos turísticos a serem explorados?

(X) Muito promissores

( ) Promissores

( ) Pouco promissores

( ) Inexistente

28. Este município produz alguma forma de artesanato que sirva como atrativo turístico de natureza cultural?

(X) $\operatorname{Sim}$

( ) Não

( ) Desconhece

( ) Outros

29. Nesse Município, nos últimos 3 anos, foi instalado algum empreendimento de destaque na área de turismo?

(X) Sim

( ) Não

( ) Desconhece

( ) Outros 
30. Que tipo de empreendimento?

(X) Hotéis

( ) Pousadas

( ) Restaurantes

( ) Desconhece

( ) Outros

31. Nos últimos 3 anos, houver algum caso de fechamento de empreendimentos de destaque na área do turismo?

( ) Sim

( ) Não

(X) Desconhece

( ) Outros

32. Na sua opinião, qual município (dessa região do estado ou do Brasil) é o mais forte concorrente turístico desse município? PIRINOPÓLIS, ALTO PARAíSO.

\section{MATERIAL DE DIVULGAÇÃO E INFROMAÇÃO}

33. Que material de divulgação e/ou informação sobre o empreendimento tem sido distribuído aos seus clientes?

( ) Folder

( ) Catálogos

( ) Jornal/ Revistas

( ) Rádio e Televisão

( ) Desconhece

(X) Nenhum

( ) Outros

34. Com que freqüência tem colocado esse material de divulgação e/ou informação à disposição de seus clientes?

( ) Permanentemente 
( ) Geralmente disponibiliza

( ) Raramente disponibiliza

(X) Nenhum

( ) Outros

35. Hierarquize os meios de divulgação desse estabelecimento.

( ) Mala direta/ correio

( ) Boca-a-boca

( ) Jornais/ revistas

( ) Rádio

( ) Televisão

(X) Nenhum

( ) Outros

RELAÇÃO COM O TRADE* TURÍSTICO

( ${ }^{*} T R A D E$ - agências e operadoras de turismo, hospedagem e transporte)

36. Esse estabelecimento recebe pedidos de reservas para turismo através de agências de viagem?

( ) Sim

(X) Não

( ) Desconhece

( ) Outros

37. Você mantém algum tipo de relacionamento comercial com parceiros do turismo?

( ) Sim

(X) Não

( ) Desconhece

( ) Outros 
38. Como avalia a qualidade de mão-de-obra para turismo existente no município?

(X) Boa (atende às necessidades)

( ) Regular (em parte)

( ) Péssima (não atende)

( ) Outros

39. Quais os principais problemas encontrados em relação à mão-de-obra nesse município

R: NÃO É QUALIFICADA

40. Como classifica a rotatividade de seus funcionários em turismo no município?

( ) Alta (acima de 50\%)

(X) Baixa (de 21 a 50\%)

( ) Media (até 20\%)

( ) Não Existe

( ) Outros...NÃO É UM EMPREENDIMENTO TURÍSTICO AINDA..

ADMINISTRAÇÃO AMBIENTALMENTE RESPONSÁVEL

41. Qual a destinação do lixo gerado pelas atividades da fazenda?

( ) Coleta pública

(X) Enterrado

( ) Amontoado ao ar livre

( ) Jogado em aterro sanitário

(X) Queimado

( ) Reciclagem

( ) Nenhum

( ) Outros

42. Qual o destino dos esgotos gerados?

( ) Direto para o rio 
( ) Sistema público de colete

( ) Sistema de tratamento próprio

(X) Outros...FOSSA SEPTICA

RELAÇÃO AO LIXO OU ESGOTO DESSE ESTABELECIMENTO?

43. Qual o tipo de abastecimento de água que a fazenda utiliza?

( ) Abastecimento público

( ) Poço artesiano

(X) Capacitação direta do rio

( ) Capacitação direta da nascente

( ) Outros

44. A água utilizada passa por algum tratamento?

( ) $\operatorname{Sim}$

(X) Não

( ) Outros

45. Especifique qual o tipo de tratamento:

( ) Cloração

( ) Filtragem

( ) Prefeitura

( ) Decantação

( ) Desconhece

(X) Nenhum

( ) Outros

46. Quais as fontes de energia utilizadas por esse estabelecimento?

(X) Energia elétrica de rede pública

( ) Geração própria

( ) Os dois sistemas são conciliados 
( ) Outros.

47. Atualmente, esse estabelecimento esta tendo algum tipo de problemas com o fornecimento de energia elétrica?

( ) Sim

( ) Não

(X) As vezes

48. Que tipos de problemas estão ocorrendo com o fornecimento de energia elétrica?

( ) Interrupções freqüentes

( ) Variações bruscas de voltagem

(X) Alto custo de tarifas

( ) Outros..INSTABILIDADE QUANDO TEM CHUVA.

49. Esse estabelecimento desenvolve:

( ) Reutilização de Materiais de Consumo

( ) Utilização de Materiais Reciclados

(X) Utilização de Materiais de Consumo Biodegradáveis

( ) Educação Ambiental

( ) Horta Orgânica

( ) Viveiro de Mudas Nativas

( ) Nenhuma das alternativas anteriores

( ) Outros

OPINIÃO FINAL

50. Indique os cinco principais problemas que dificultam o desenvolvimento do turismo nesse município e/ou região:
(1ํ) Sinalização
(1ํ) SINALIZAÇÃO
$\left(2^{\circ}\right)$ Incentivo do governo
(2º) INFRA-ESTRUTURA BÁSICA 

(3ํ) Infra-estrutura básica
(3) SAZONALIDADE
(4º) Sazonalidade
(4º) ACESSO
(5) Acesso
(5) INCENTIVO DO GOVERNO

51. Cite cinco principais pontos positivos que favorecem o desenvolvimento do turismo nesse município/região:

(1ํㅜ) Biodiversidade

(2º) Beleza paisagista do local

(3ํ) Potencial turístico para o ecoturismo

(4º) Grande número de rios com grande potencial para atividades aquáticas

(5ํ) Vegetação (cerrado) predominante de grande beleza

(1ํ) BELEZA PAISAGISTA DO LOCAL

(2º) POTÊNCIAL TURÍSTICO PARA O ECOTURISMO

(3) GRANDE NÚMERO DE RIOS COM GRANDE POTÊNCIAL PARA ATIVIDADES AQUÁTICAS

(4º) VEGETAÇÃO (CERRADO) PREDOMINANTE DE GRANDE BELEZA

(5ํ) BIODIVERSIDADE

52. Em relação ao desenvolvimento do turismo nesse município o Sr. Gostaria de fazer algum comentário ou tecer alguma consideração? QUANDO HAVERÁ RETORNO POR CAUSA DA ZAZONALIDADE. 


\section{APÊNDICE A}

Memorial Descritivo - Levantamento do Registro Geral da Escritura de Compra e Venda da Fazenda Rancho Grande do Município de Formosa Goiás/GO.

Defere-se ao presente memorial os primeiros proprietários Dr. Carlos Magno Campos da Rocha e Dr. Wenceslau J. Goedert. No município de Formosa - GO.

O referido imóvel tem seus lotes delimitados por uma parte de terras situadas fazenda "Água Fria", do Vale do Paraná, faz parte da divisão do Imóvel, com área de 40 (quarenta) alqueires de campos e cultura, ou seja, 193.60ha (cento e noventa e três hectares e sessenta ares). O valor do contrato em 26 de Novembro de 1983 era de 16.500.000.00 (dezesseis milhões e quinhentos mil cruzeiros) No ano de 1948 o documento foi Registrado no Cartório no dia 10 de Janeiro. Informações obtidas através do Cartório de Registro Geral de Hipoteca. O imóvel está cadastrado no INCRA com área total de 509,6ha (quietos e nove hectares e seis ares), com o nome de registro de Rancho Grande II.

A outorgante e vendedora Nadir Alves de Souza, fazendeira, benfeitora herdou após o falecimento de Vicente Vieira de Souza. Em 25 de outubro de 1979 a propriedade tinha o valor total de $\operatorname{Cr} \$ 316.000,00$, porém a proprietária vendeu parte de suas terras adquirida no inventário dos bens.

Os limites gerais "começam do ponto de confluência do córrego Capivara no ribeirão Água Fria, subindo córrego Capivara, com direção geral SW e distancia de 3.970.00 metro, até o marco M-31, onde dobra à esquerda, com rumo 000' $\mathrm{S}$, confrontando com O quinhão no. 8 (oito) de América Alves Ferreira e Joaquim Pinto Monteiro até o Marco M - 32, a 1.152,00 metros de distancia . Dobra a esquerda, com direção geral SE e NE, pelo Ribeirão Água Fria abaixo, até o ponto de confluência com o córrego Capivara, ponto de partida deste limite".

A escritura pública de compra e venda realizada em 15 de Abril de 1980, pelos outorgados compradores Drs. Wesceslau J. Goedert e Carlos Magno Campos da Rocha teve o valor de 3.000.000,00 (três milhões de cruzeiros), em comum acordo 
sem quaisquer dúvidas e ônus, real, inclusive hipotecas, mesmo legal de: Primeiro - um quinhão de terras de no. 12 (doze), situados no município da fazenda "Água Fria" (ares e setenta e três centiares) de terra de campo, e com os seguintes limites. Começa no marco M-39, cravado na margem do Ribeirão Água Fria, seguinte com rumo 000' S e distância de 996,00 metros (novecentos e noventa e seis metros); na confrontação com o quinhão de $n^{\circ} .11$ (onze) de Alzira Alves Ferreira, até o marco $\mathrm{M}-40$, a esquerda, com rumo 9000' e distância de 1.709,00 metros (Hum mil setecentos e nove metros); confrontando com o quinhão nํ. 1 (hum) de David José de Couto, Carlos Pereira de Lacerda, Docanti Martins Vieira e outros, onde encontra o marco $\mathrm{M}-41$, deflete a esquerda, na confrontação citada, com rumo 705' NE e distância de 847,00 metros (oitocentos e quarenta e sete metros), até ao marco $M-42$, onde torna a defletir ligeiramente à esquerda, com rumo 000" $\mathrm{N}$ e distância de 2.115,00 metros (dois mil, cento e quinze metros);na confrontação citada, até ao marco $\mathrm{M}-43$, na margem do Ribeirão com direção geral SW e distância aproximada de 2.781,00 metros (dois mil, setecentos e oitenta e hum metros), para o marco M- 3 que foi o ponto inicial da presente descrição perimétrica.

Segundo - uma parte de terras, dividida e demarcada, situada na fazenda denominada "Água Fria" deste Município, com área de mais ou menos 36,00ha (trinta e seis alqueires), sendo 6 (seis) alqueires de matos e o restante de campos naturais; os quais correspondem a 174,24,00ha 9cento e setenta e quatro hectares, vinte e quatro ares), e com os seguintes limites: começa em marco $M-V$, à margem direita do Ribeirão Água Fria, dividindo com Rafael Azevedo do Couto. Do Ribeirão Água Fria, ao lado esquerdo com 100 (cem) metros, até a estrada de rodagem; por esta acima com distância de 1.920,00 metros (Hum mil, novecentos e vinte quatro); até encontrar o marco $\mathrm{M}-\mathrm{X}$, em divisa com o mesmo vendedor, Sebastião Resende, dobra a direita com distância de 1.990,00 metros (Hum mil novecentos e noventa metros) até a barra da Capivara. Os imóveis descritos e caracterizados acima, forma vendidos pelo preço certo e ajustado de $\operatorname{Cr} \$ 3.000 .000,00$ (três milhões de cruzeiros), sendo $\operatorname{Cr} \$ 1.350 .000,00$ (Hum milhão, seiscentos e cinqüenta mil cruzeiros), pagos neste ato em moeda corrente e legal do país e Cr\$ 1.650.000,00 (Hum milhão, trezentos e cinqüenta mil cruzeiros), representados por uma nota promissória de igual valor, vencível em 14 de outubro de 1980, emitidas 
pelos outorgados compradores, a favor dos outorgantes vendedores. O documento foi registrado em cartório no ano de 1980 do dia 18 de Abril registrado em livro.

A última escritura de compra e venda realizada no cartório de registro geral de hipotecas realizado pelo proprietário oficial Dr. Carlos Magno Campos da Rocha dono da propriedade Fazenda Rancho Grande, foi no dia 16 de março de 1989.

Os outorgantes foram Dr. Wesceslau J. Goedert e sua esposa Dra. Clara Oliveira Goedert, como valor do contrato Cz\$29.000,00 (Vinte e nove mil cruzados novos). Primeiro: $50 \%$ (cinqüenta por cento) do quinhão de terras №. 12 (doze), situados neste município, na Fazenda "Água Fria", correspondendo a uma área de 166,03,75ha (cento e sessenta e seis hectares, três ares e setenta e cinco centiares), sendo 2,12,88ha. (dois hectares, doze ares e oitenta e oito centiares) de mato e 163,90,87ha (cento e sessenta e três hectares, noventa ares e oitenta e sete centiares) em terras de campo, em comum com o adquirente e dentro dos limites.

Segundo: $50 \%$ (cinqüenta por cento) de uma parte de terras, situadas na Fazenda "Água Fria”, deste município, correspondendo a uma área de mais ou menos 18,00 alqueires (dezoito alqueires), sendo 3,00 alqueires (três alqueires) de matos e 0 restante de campos naturais; os quais correspondem a 87,00ha (oitenta e sete hectares e doze ares), em comum com o adquirente e dentro dos limites.

Terceiro: $50 \%$ (cinqüenta por cento) de uma parte em uma gleba de terras na Fazenda "Água Fria", do Vale do Paraná, deste município, identifique pelo quinhão no. 9 (nove) da divisão do imóvel, correspondem a uma área de 20,00ha (vinte alqueires de campo e cultura), ou seja, 96,80,00ha. (noventa e seis hectares e oitenta ares) em comum com o adquirente e dentro dos limites. Em 1989 de abril do dia 18 o documento foi registrado no Cartório. 


\section{APÊNDICE B}

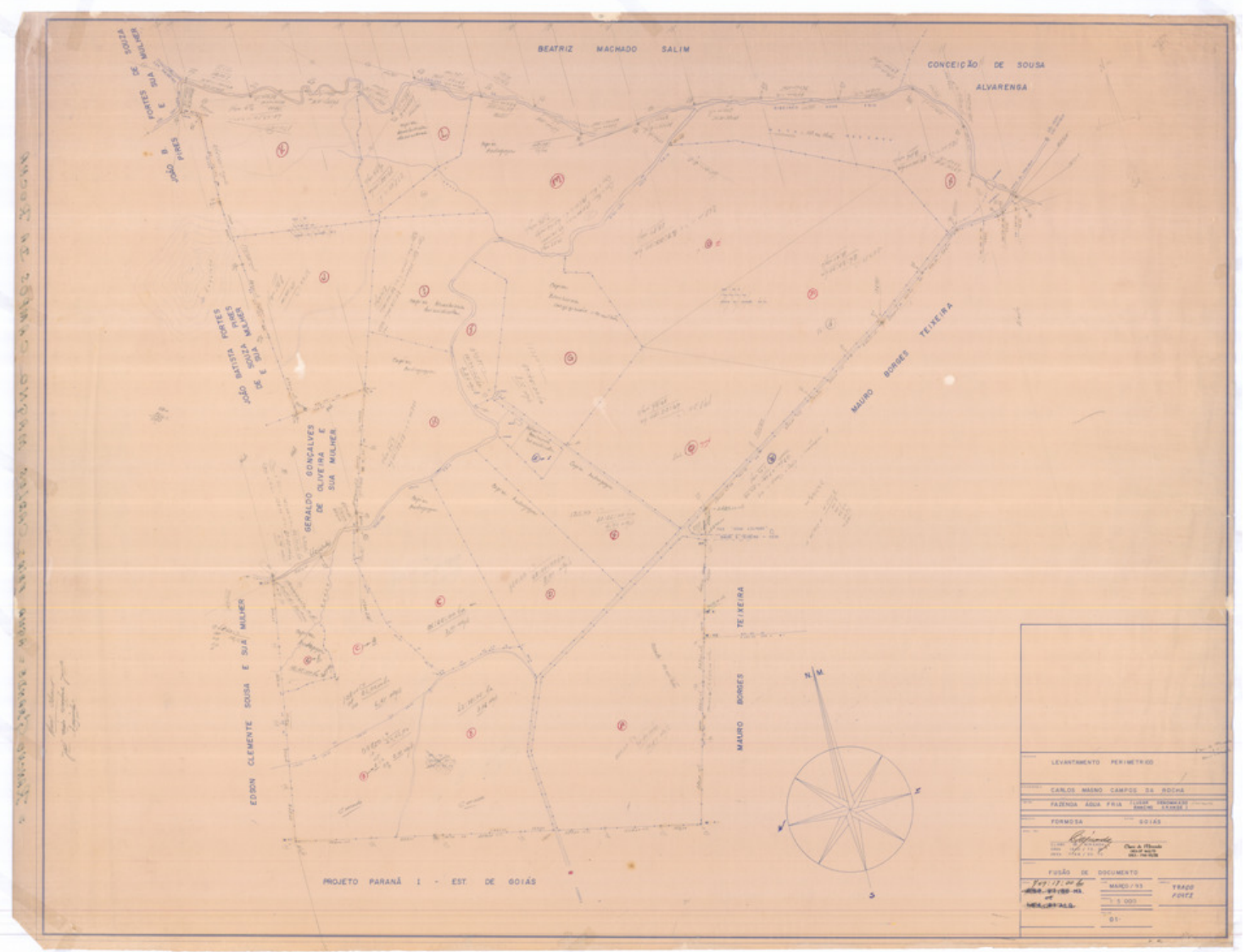

Ilustração 1. Planta cadastral da propriedade Fazenda Rancho Grande. 


\section{APÊNDICE C}

Na visita técnica realizada do dia 21 de março a 23 de março de 2008, foi aplicado o questionário sobre a Fazenda Rancho Grande ao proprietário, Sr. Carlos Magno Campos da Rocha, com o propósito de obter informações precisas da propriedade. As primeiras 14 (quatorze) perguntas tinham como objetivo principal saber a respeito da caracterização do empreendimento e financiamento.

As primeiras perguntas correspondem à caracterização como razão social que é "Fazenda Rancho Grande", nome fantasia que se matem igual ao da razão social, o tempo do estabelecimento instalado no município é de "28 (vinte oito) anos", quantidade de proprietários "atualmente apenas o proprietário Sr. Carlos Magno". A natureza do estabelecimento é única, os fatores que influenciaram na compra do local foi a "paixão pela agronomia", valor inicial de compra realizado "até 50 (cinqüenta) mil reais" na moeda atual, o retorno do investimento aplicado na fazenda não foi satisfatório ao proprietário. A maior atividade lucrativa do estabelecimento é a "criação de gado de leite" de acordo com Dr. Carlos Magno, em segundo vem a venda permanente de gado e a produção de milho para alimentação dos animas.

Perguntas referentes a financiamento começam na questão 08 (oito), questionando se utilizou alguma linha de crédito, e a resposta foi "sim", e a escolha dos tipos de créditos foram "Custeio Agropecuário (BB)" e "Fundo de Centro- Oeste (FCO)", e sua finalidade foi para "Manutenção e Compra de animais de leite", o proprietário disse ainda que encontrou dificuldades para saldar a dívida e diz que taxas menores facilitariam a quitação do financiamento.

As Perguntas de 15 (quinze) a 18 (dezoito) referem-se a Investimentos, como quais os tipos de investimentos tem sido aplicados e os recursos advindos do seu lucro líquido referem-se que "ultimamente a infra-estrutura basicamente", futuramente se existe algum interesse de investir no mesmo ou em outros negócios a resposta foi positiva, o proprietário pretende fazer a infra-estrutura Turística na Fazenda Rancho Grande e também usar os recursos próprios com a produção de leite, ele também acredita que o município tem potencial para investir em hotéis e restaurantes. 
As perguntas de avaliação da atividade turística como os tipos de turismo praticados no município são respondidas por turismo de aventura e turismo ecológico sendo os predominantes, a avaliação do desenvolvimento da atividade turística que o proprietário conclui é que ela é pouco desenvolvida e muito lenta, porém acredita possui perspectivas de desenvolvimento e crescimento para atividade, conclui que o maior potencial da atividade seria turismo de aventura e turismo ecológico, além do turismo rural que seria o diferencial da sua propriedade. Na geração de emprego avalia o turismo, atualmente, como gerador de médias oportunidades de empregos, mas acredita que futuramente poderá ter capacidade de gerar muitas oportunidades, essa capacidade vem dos atrativos naturais e culturais como o fato de nascerem 47 (quarenta e sete) rios em Formosa-GO, por isso, avalia o potencial dos recursos naturais e culturais como possibilidades muito promissoras de construírem atrativos turísticos a serem explorados com sustentabilidade, o município ainda produz formas de artesanato que servem como atrativos turísticos de natureza cultural.

Questionado se nos últimos três anos foi instalado algum tipo de empreendimento de destaque na área de turismo a resposta foi "sim", sendo "hotéis", e desconhece se nos últimos três anos algum empreendimento turístico teria fechado. Acredita que o município de Formosa tem concorrentes fortes como Pirenopólis e Alto Paraíso.

Busca-se saber nas próximas perguntas se há material de divulgação e informação utilizado para promover a fazenda, porém não há esse tipo de divulgação pois a propriedade ainda não utiliza atividades turísticas na propriedade.

O proprietário busca enterrar e queimar o lixo gerado pelas atividades da fazenda, o esgoto gerado também possui um destino que é a fossa séptica, a água utilizada na propriedade é através da capacitação direta do rio, sem utilização de um tipo de tratamento como cloração, filtragem e decantação. A energia é fornecida pela rede elétrica pública que às vezes proporciona alguns problemas como alto custo de tarifas e instabilidade quando chove.

Na finalização do questionário tenta-se mostrar a opinião final do entrevistado, foi solicitado que apontasse problemas que dificultam o desenvolvimento do turismo, sendo observadas a sinalização, sazonalidade, e incentivo do governo. Na última pergunta do questionário aplicado, solicita-se apresentar os pontos positivos que 
favorecem o desenvolvimento do turismo, sendo observadas a beleza paisagista do local, o potencial turístico para o ecoturismo, o grande número de rios com grande potencial para atividades aquáticas, a vegetação (cerrado) predominante de grande beleza, e a biodiversidade.

Esse questionário pode ser observado na íntegra no anexo desse trabalho de conclusão de especialização. 


\section{APÊNDICE D}

Tabela 24. Fluxo de caixa mensal - Ano 1.

\begin{tabular}{|c|c|c|c|c|c|c|c|c|c|c|c|c|c|}
\hline \multicolumn{14}{|c|}{ FLUXO DE CAIXA MENSAL - ANO 1} \\
\hline \multicolumn{2}{|c|}{ DESCRIÇÃO } & \multirow{2}{*}{ MÊS 1} & \multirow{2}{*}{ MÊS 2} & \multirow{2}{*}{ MÊS 3} & \multirow{2}{*}{ MÊS 4} & \multirow{2}{*}{ MÊS 5} & \multirow{2}{*}{ MÊS 6} & \multirow{2}{*}{ MÊS 7} & \multirow{2}{*}{ MÊS 8} & \multirow{2}{*}{ MÊS 9} & \multirow{2}{*}{ MÊS 10} & \multirow{2}{*}{ MÊS 11} & \multirow{2}{*}{ MÊS 12} \\
\hline INVESTIMENTO & $\begin{array}{c}- \\
174.007,27 \\
\end{array}$ & & & & & & & & & & & & \\
\hline \multicolumn{2}{|l|}{ SALDO INICIAL } & $35.850,27$ & $42.463,64$ & $49.078,24$ & $55.694,06$ & $62.311,13$ & $68.929,46$ & $75.549,04$ & $82.169,88$ & $88.792,01$ & $95.415,42$ & $102.040,13$ & $108.666,14$ \\
\hline \multicolumn{2}{|l|}{ TOTAL DE ENTRADAS } & $19.675,00$ & $19.676,23$ & $19.677,46$ & $19.678,70$ & $19.679,95$ & $19.681,21$ & $19.682,48$ & $19.683,76$ & $19.685,04$ & $19.686,34$ & $19.687,64$ & $19.688,96$ \\
\hline \multicolumn{2}{|l|}{ RECEITA DE VENDAS } & $19.500,00$ & $19.500,00$ & $19.500,00$ & $19.500,00$ & $19.500,00$ & $19.500,00$ & $19.500,00$ & $19.500,00$ & $19.500,00$ & $19.500,00$ & $19.500,00$ & $19.500,00$ \\
\hline \multicolumn{2}{|l|}{ RECEITA FINANCEIRA } & 175,00 & 176,23 & 177,46 & 178,70 & 179,95 & 181,21 & 182,48 & 183,76 & 185,04 & 186,34 & 187,64 & 188,96 \\
\hline \multicolumn{2}{|l|}{ TOTAL DE SAÍDAS } & $13.743,02$ & $13.743,02$ & $13.743,02$ & $13.743,02$ & $13.743,02$ & $13.743,02$ & $13.743,02$ & $13.743,02$ & $13.743,02$ & $13.743,02$ & $13.743,02$ & $13.743,02$ \\
\hline \multicolumn{2}{|l|}{ CPV/CSV $(-)$} & $5.049,00$ & $5.049,00$ & $5.049,00$ & $5.049,00$ & $5.049,00$ & $5.049,00$ & $5.049,00$ & $5.049,00$ & $5.049,00$ & $5.049,00$ & $5.049,00$ & $5.049,00$ \\
\hline \multicolumn{2}{|l|}{ COMISSÕES (-) } & 0,00 & 0,00 & 0,00 & 0,00 & 0,00 & 0,00 & 0,00 & 0,00 & 0,00 & 0,00 & 0,00 & 0,00 \\
\hline \multicolumn{2}{|l|}{ AMORTIZAÇÃO (-) } & 0,00 & 0,00 & 0,00 & 0,00 & 0,00 & 0,00 & 0,00 & 0,00 & 0,00 & 0,00 & 0,00 & 0,00 \\
\hline \multicolumn{2}{|l|}{ DEPRECIAÇÃO(-) } & 681,39 & 681,39 & 681,39 & 681,39 & 681,39 & 681,39 & 681,39 & 681,39 & 681,39 & 681,39 & 681,39 & 681,39 \\
\hline $\begin{array}{l}\text { DESPESAS } \\
\text { ADMINISTRATIVAS } \\
(-)\end{array}$ & & $3.733,26$ & $3.733,26$ & $3.733,26$ & $3.733,26$ & $3.733,26$ & $3.733,26$ & $3.733,26$ & $3.733,26$ & $3.733,26$ & $3.733,26$ & $3.733,26$ & $3.733,26$ \\
\hline $\begin{array}{l}\text { DESPESAS } \\
\text { ESPECIAIS(-) }\end{array}$ & & 0,00 & 0,00 & 0,00 & 0,00 & 0,00 & 0,00 & 0,00 & 0,00 & 0,00 & 0,00 & 0,00 & 0,00 \\
\hline $\begin{array}{l}\text { DESPESAS } \\
\text { BANCÁRIAS (-) }\end{array}$ & & 100,00 & 100,00 & 100,00 & 100,00 & 100,00 & 100,00 & 100,00 & 100,00 & 100,00 & 100,00 & 100,00 & 100,00 \\
\hline $\begin{array}{l}\text { DESPESAS } \\
\text { GERAIS (-) }\end{array}$ & & $1.869,05$ & $1.869,05$ & $1.869,05$ & $1.869,05$ & $1.869,05$ & $1.869,05$ & $1.869,05$ & $1.869,05$ & $1.869,05$ & $1.869,05$ & $1.869,05$ & $1.869,05$ \\
\hline $\begin{array}{l}\text { DESPESAS DE } \\
\text { MARKETING (-) }\end{array}$ & & 49,38 & 49,38 & 49,38 & 49,38 & 49,38 & 49,38 & 49,38 & 49,38 & 49,38 & 49,38 & 49,38 & 49,38 \\
\hline $\begin{array}{l}\text { DESPESAS DE } \\
\text { TECNOLOGIA (-) }\end{array}$ & & 180,00 & 180,00 & 180,00 & 180,00 & 180,00 & 180,00 & 180,00 & 180,00 & 180,00 & 180,00 & 180,00 & 180,00 \\
\hline IMPOSTOS (-) & & $1.164,15$ & $1.164,15$ & $1.164,15$ & $1.164,15$ & $1.164,15$ & $1.164,15$ & $1.164,15$ & $1.164,15$ & $1.164,15$ & $1.164,15$ & $1.164,15$ & $1.164,15$ \\
\hline $\begin{array}{l}\text { PROVISÃO } \\
\text { DEVED. } \\
\text { DUVIDOSOS (-) }\end{array}$ & & 916,79 & 916,79 & 916,79 & 916,79 & 916,79 & 916,79 & 916,79 & 916,79 & 916,79 & 916,79 & 916,79 & 916,79 \\
\hline SALDO & & $5.931,98$ & $5.933,21$ & $5.934,44$ & $5.935,68$ & $5.936,93$ & $5.938,19$ & $5.939,46$ & $5.940,74$ & $5.942,02$ & $5.943,32$ & $5.944,62$ & $5.945,94$ \\
\hline DEPRECIAÇÃO (+) & & 681,39 & 681,39 & 681,39 & 681,39 & 681,39 & 681,39 & 681,39 & 681,39 & 681,39 & 681,39 & 681,39 & 681,39 \\
\hline $\begin{array}{l}\text { FLUXO LÍQUIDO } \\
\text { DE CAIXA }\end{array}$ & & $42.463,64$ & $49.078,24$ & $55.694,06$ & $62.311,13$ & $68.929,46$ & $75.549,04$ & $82.169,88$ & $88.792,01$ & $95.415,42$ & $102.040,13$ & $108.666,14$ & $115.293,47$ \\
\hline
\end{tabular}


Tabela 25. Fluxo de caixa anual.

\begin{tabular}{|c|c|c|c|c|c|c|}
\hline \multicolumn{7}{|l|}{ FLUXO DE CAIXA ANUAL } \\
\hline DESCRIÇÃO & ANO 1 & ANO 2 & ANO 3 & ANO 4 & ANO 5 & Total \\
\hline INVESTIMENTO INICIAL & & & & & & $(174.007,27)$ \\
\hline SALDO INICIAL & $35.850,27$ & $117.476,24$ & $195.418,77$ & $236.859,76$ & $268.998,75$ & $35.850,27$ \\
\hline TOTAL DE ENTRADAS & $236.182,77$ & $268.424,70$ & $304.754,06$ & $345.666,03$ & $391.713,95$ & $1.155 .027,56$ \\
\hline RECEITA DE VENDAS & $236.182,77$ & $268.424,70$ & $304.754,06$ & $345.666,03$ & $391.713,95$ & $1.155 .027,56$ \\
\hline $\begin{array}{l}\text { TOTAL DE } \\
\text { SAÍDAS }\end{array}$ & $164.916,23$ & $200.056,96$ & $272.315,33$ & $322.138,14$ & $354.901,73$ & $959.426,65$ \\
\hline CPV/CSV $(-)$ & $60.588,03$ & $72.485,63$ & $115.796,68$ & $128.331,94$ & $110.552,77$ & $377.202,27$ \\
\hline COMISSÕES (-) & 0,00 & 0,00 & 0,00 & 0,00 & 0,00 & 0,00 \\
\hline $\begin{array}{l}\text { AMORTIZAÇÃO } \\
(-)\end{array}$ & 0,00 & 0,00 & 0,00 & 0,00 & 0,00 & 0,00 \\
\hline $\begin{array}{l}\text { DEPRECIAÇÃO(- } \\
)\end{array}$ & $8.176,66$ & $7.130,10$ & $6.264,19$ & $5.544,47$ & $4.943,22$ & $27.115,41$ \\
\hline $\begin{array}{l}\text { DESPESAS } \\
\text { ADMINISTRATIVAS (-) }\end{array}$ & $44.799,12$ & $54.300,00$ & $69.510,00$ & $89.283,00$ & $114.987,90$ & $257.892,12$ \\
\hline DESPESAS ESPECIAIS(-) & 0,00 & 0,00 & 0,00 & 0,00 & 0,00 & 0,00 \\
\hline DESPESAS BANCÁRIAS (-) & $1.200,00$ & $1.560,00$ & $2.028,00$ & $2.636,40$ & $3.427,32$ & $7.424,40$ \\
\hline DESPESAS GERAIS (-) & $22.428,61$ & $29.157,20$ & $37.904,36$ & $49.275,66$ & $64.058,36$ & $138.765,83$ \\
\hline $\begin{array}{l}\text { DESPESAS DE MARKETING } \\
(-)\end{array}$ & 592,50 & 770,25 & $1.001,33$ & $1.301,72$ & $1.692,24$ & $3.665,80$ \\
\hline $\begin{array}{l}\text { DESPESAS DE TECNOLOGIA } \\
(-)\end{array}$ & $2.160,00$ & $2.808,00$ & $3.650,40$ & $4.745,52$ & $6.169,18$ & $13.363,92$ \\
\hline IMPOSTOS (-) & $13.969,80$ & $19.522,93$ & $22.167,97$ & $25.146,80$ & $31.217,66$ & $31.217,66$ \\
\hline $\begin{array}{l}\text { PROVISÃO DEVED. } \\
\text { DUVIDOSOS }(-)\end{array}$ & $11.001,51$ & $12.322,85$ & $13.992,40$ & $15.872,63$ & $17.853,08$ & $53.189,39$ \\
\hline SALDO & $71.266,54$ & $68.367,74$ & $32.438,73$ & $23.527,89$ & $36.812,21$ & $195.600,91$ \\
\hline $\begin{array}{l}\text { DEPRECIAÇÃO } \\
(+)\end{array}$ & $8.176,66$ & $7.130,10$ & $6.264,19$ & $5.544,47$ & $4.943,22$ & $27.115,41$ \\
\hline RECEITA FINANCEIRA & $2.182,77$ & $2.444,70$ & $2.738,06$ & $3.066,63$ & $3.434,63$ & $10.432,16$ \\
\hline FLUXO LÍQUIDO D & $117.476,24$ & $195.418,77$ & $236.859,76$ & $268.998,75$ & $314.188,81$ & $443.006,02$ \\
\hline
\end{tabular}


Tabela 26. Demonstrativo anual.

\begin{tabular}{|c|c|c|c|c|c|c|}
\hline \multicolumn{7}{|c|}{ DEMONSTRAÇÃO DE RESULTADOS ANUAL } \\
\hline QUANTIDADE & Preço Unit. & ANO 1 & ANO 2 & ANO 3 & ANO 4 & ANO 5 \\
\hline 1.560 & 150,00 & $234.000,00$ & & \multirow{5}{*}{$302.016,00$} & \multirow{5}{*}{$342.599,40$} & \\
\hline 1.716 & 155,00 & & $265.980,00$ & & & \\
\hline 1.888 & 160,00 & & & & & \\
\hline 2.076 & 165,00 & & & & & \\
\hline 2.284 & 170,00 & & & & & $388.279,32$ \\
\hline \multicolumn{2}{|l|}{$\begin{array}{l}\text { 1. RECEITA } \\
\text { BRUTA }\end{array}$} & $\mathrm{R} \$ 234.000,00$ & $\mathrm{R} \$ 265.980,00$ & $\mathrm{R} \$ 302.016,00$ & $\mathrm{R} \$ 342.599,40$ & $\mathrm{R} \$ 388.279,32$ \\
\hline 2.1 IMPOSTOS & $\begin{array}{l}\text { SUPER } \\
\text { SIMPLES }\end{array}$ & $5,97 \%$ & $7,34 \%$ & $7,34 \%$ & $7,34 \%$ & $8,04 \%$ \\
\hline \multicolumn{2}{|c|}{ VALOR } & $13.969,80$ & $19.522,93$ & $22.167,97$ & $25.146,80$ & $31.217,66$ \\
\hline 3. Comissões (-) & $0,0 \%$ & 0,00 & 0,00 & 0,00 & 0,00 & 0,00 \\
\hline \multicolumn{2}{|c|}{ 4. RECEITA LÍQUIDA(=) } & $220.030,20$ & $246.457,07$ & $279.848,03$ & $317.452,60$ & $357.061,66$ \\
\hline \multicolumn{2}{|l|}{ 5. CPV/CSV $(-)$} & $60.588,03$ & $72.485,63$ & $115.796,68$ & $128.331,94$ & $110.552,77$ \\
\hline \multicolumn{2}{|c|}{ 6. LUCRO BRUTO(=) } & $159.442,17$ & $173.971,44$ & $164.051,35$ & $189.120,67$ & $246.508,89$ \\
\hline \multicolumn{2}{|c|}{ 7. MARGEM DE CONTF } & $72 \%$ & $71 \%$ & $59 \%$ & $60 \%$ & $69 \%$ \\
\hline \multicolumn{2}{|c|}{$\begin{array}{l}\text { 8. DESPESAS } \\
\text { OPERACIONAIS(=) }\end{array}$} & $90.358,40$ & $108.048,40$ & $134.350,67$ & $168.659,40$ & $213.131,30$ \\
\hline \multicolumn{2}{|c|}{ 8.1 AMORTIZAÇÃO (-) } & 0,00 & 0,00 & 0,00 & 0,00 & 0,00 \\
\hline \multicolumn{2}{|c|}{ 8.2 DEPRECIAÇÃO (-) } & $8.176,66$ & $7.130,10$ & $6.264,19$ & $5.544,47$ & $4.943,22$ \\
\hline \multicolumn{2}{|c|}{ 8.3 DESP. ADMINISTRATIVAS (-) } & $44.799,12$ & $54.300,00$ & $69.510,00$ & $89.283,00$ & $114.987,90$ \\
\hline \multicolumn{2}{|c|}{ 8.4 DESPESAS ESPECIAIS (-) } & 0,00 & 0,00 & 0,00 & 0,00 & 0,00 \\
\hline \multicolumn{2}{|c|}{ 8.5 DESP. BANCÁRIAS (-) } & $1.200,00$ & $1.560,00$ & $2.028,00$ & $2.636,40$ & $3.427,32$ \\
\hline \multicolumn{2}{|c|}{ 8.6 DESPESAS GERAIS (-) } & $22.428,61$ & $29.157,20$ & $37.904,36$ & $49.275,66$ & $64.058,36$ \\
\hline \multicolumn{2}{|c|}{ 8.7 DESP. DE MARKETING (-) } & 592,50 & 770,25 & $1.001,33$ & $1.301,72$ & $1.692,24$ \\
\hline \multicolumn{2}{|c|}{ 8.8 DESP. DE TECNOLOGIA (-) } & $2.160,00$ & $2.808,00$ & $3.650,40$ & $4.745,52$ & $6.169,18$ \\
\hline \multicolumn{2}{|c|}{ 8.9 PROV. DEVED. DUVIDOS.(-) } & $11.001,51$ & $12.322,85$ & $13.992,40$ & $15.872,63$ & $17.853,08$ \\
\hline \multicolumn{2}{|c|}{ 9. RES. OPERACIONAL } & $69.083,77$ & $65.923,04$ & $29.700,67$ & $20.461,26$ & $33.377,59$ \\
\hline \multicolumn{2}{|c|}{ 10. RECEITAS FINANCEIRAS $(+)$} & $2.182,77$ & $2.444,70$ & $2.738,06$ & $3.066,63$ & $3.434,63$ \\
\hline 11. I. RENDA (-) & $0 \%$ & 0,00 & 0,00 & 0,00 & 0,00 & 0,00 \\
\hline LUCRO/PREJUÍ & QUIDO & $\mathrm{R} \$ 71.266,54$ & $\mathrm{R} \$ 68.367,74$ & $\mathrm{R} \$ 32.438,73$ & $\mathrm{R} \$ 23.527,89$ & $\mathrm{R} \$ 36.812,21$ \\
\hline
\end{tabular}


Tabela 27. Indicadores financeiros.

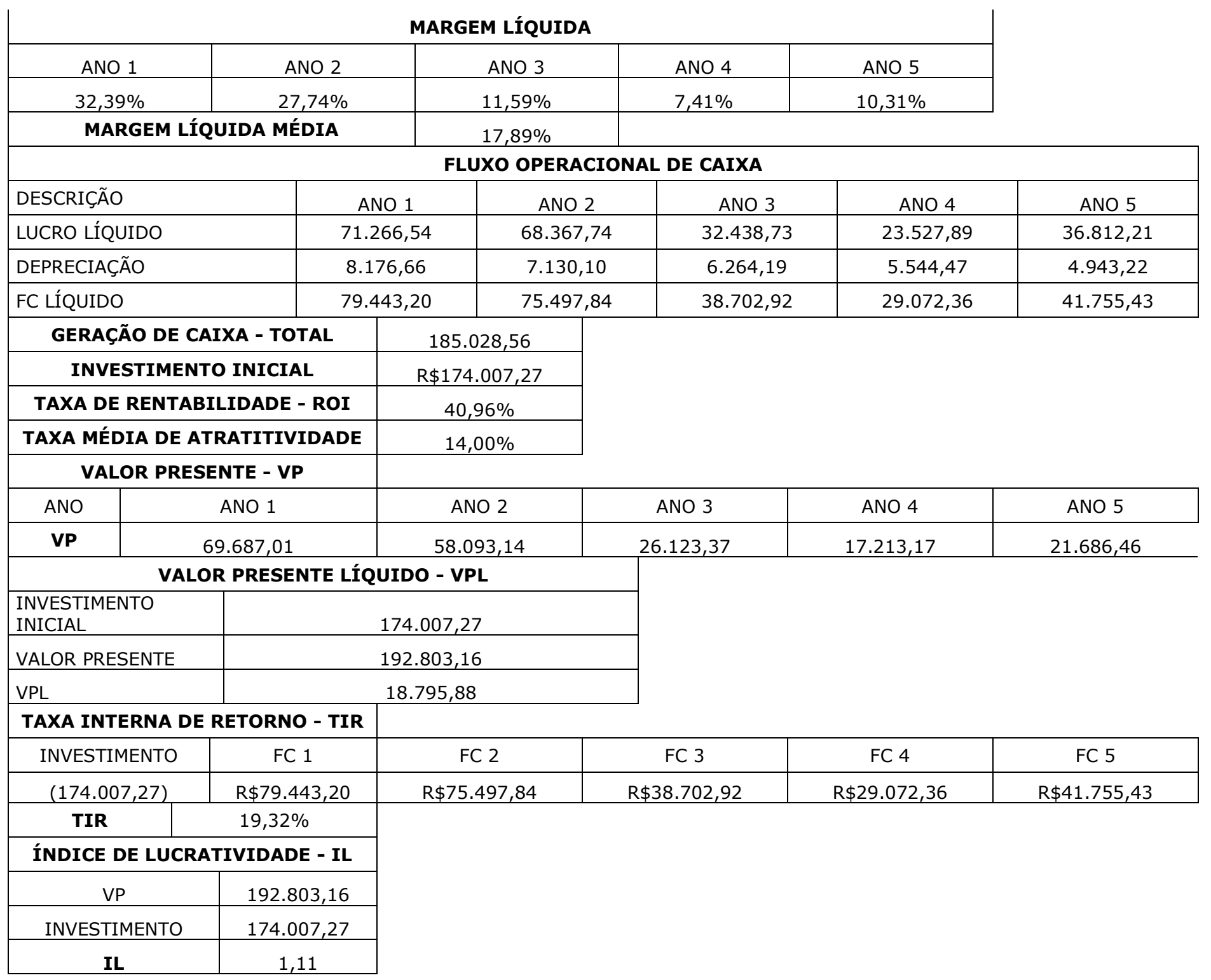

